INTER NATIONAL MONETARY FUND
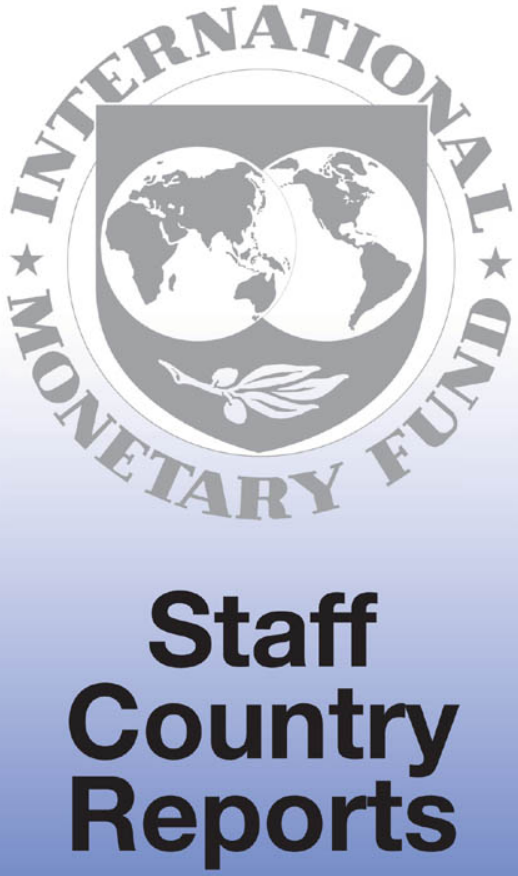
IMF Staff Country Report No. 99/44

\section{United Kingdom: Selected Issues}

This Selected Issues report on the United Kingdom was prepared by a staff team of the International Monetary Fund as background documentation for the periodic consultation with this member country. As such, the views expressed in this document are those of the staff team and do not necessarily reflect the views of the Government of the United Kingdom or the Executive Board of the IMF.

Copies of this report are available to the public from International Monetary Fund • Publication Services 700 19th Street, N.W. - Washington, D.C. 20431

Telephone: (202) 623-7430 - Telefax: (202) 623-7201

Telex (RCA): 248331 IMF UR

E-mail: publications@imf.org

Internet: http://www.imf.org

Price: $\$ 15.00$ a copy

\section{International Monetary Fund}

Washington, D.C. 


\section{INTERNATIONAL MONET ARY FUND}

\section{UNITED KINGDOM}

\section{Selected Issues}

Prepared by Hossein Samiei, Jan Kees Martijn, Zenon Kontolemis (all EU1), and Leonardo Bartolini (RES)

Approved by European I Department

February 17, 1999

Contents

Basic Data 3

I. Operational Independence and the Conduct of Monetary Policy in the United Kingdom

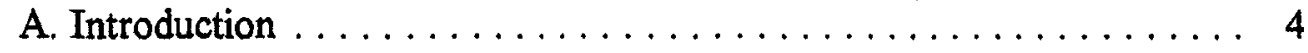

B. The U.K. Monetary Framework Since $1992 \ldots \ldots \ldots \ldots \ldots \ldots$

C. The Case for Central Bank Independence .............. 10

D. Gradualism in Monetary Decisions Making . . . . . . . . . . 13

E. Transparency in the New Framework . . . . . . . . . . . 15

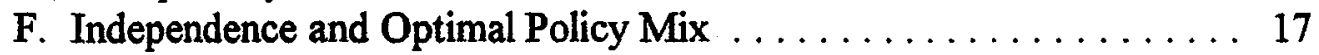

G. Concluding Remarks $\ldots \ldots \ldots \ldots \ldots \ldots \ldots \ldots \ldots \ldots \ldots 20$

$\underline{\text { References } \ldots \ldots \ldots \ldots \ldots \ldots \ldots \ldots \ldots \ldots \ldots \ldots \ldots \ldots \ldots \ldots \ldots \ldots \ldots} 2$

II. The Financial Services Authority: Structure, Mandate, and Policy Issues . . . . 25

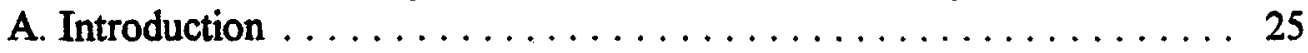

B. The FSA's Main Regulatory Responsibilities $\ldots \ldots \ldots \ldots \ldots \ldots 25$

C. Establishing a Single Regulator of U.K. Financial Markets ...... 30

D. Consumer Protection .................... 33

E. Coordination of Lender-of-Last-Resort and Supervisory Responsibilities35

F. "Constructive" Ambiguity? . . . . . . . . . . . . . . . . . 41

G. Regulatory Reform and Financial Innovation $\ldots \ldots \ldots \ldots \ldots .42$

H. Concluding Remarks

References

48

III. United Kingdom Business Cycle and EMU Entry $\ldots \ldots \ldots \ldots \ldots \ldots$

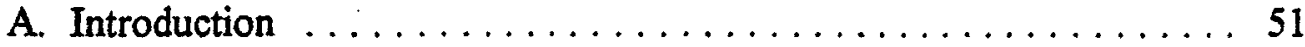

B. Properties of the U.K. Business Cycle .............. 54

C. Policy Variables and the Cycle: A Structural VAR Analysis ...... 59 


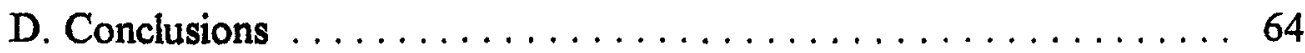

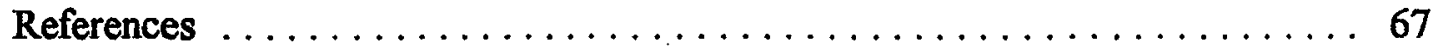

Text Tables

III. $\quad 1 \quad$ GDP Correlation Coefficients for Growth Cycles (HP Filter) . . . . . . 55

2. Counts and Correlation of Business Cycles Regimes for the U.K.

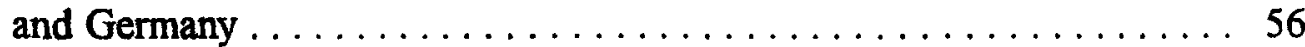

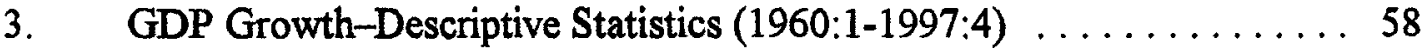

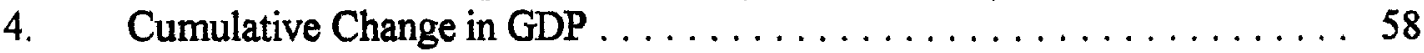

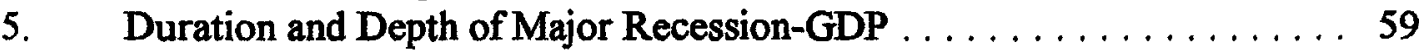

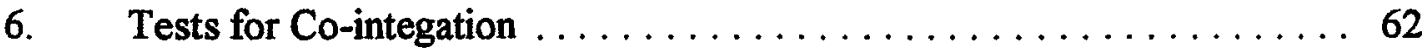

Text Box

1. Policy Games with Central Bank Independence ............... 19

Figures

III. 1. Selected Countries: Real GDP ................... 52

2. U.K. Actual and Predicted GDP Growth . . . . . . . . . . . . . . 65

Appendix

II. 1. Relationships between the FSA, The Bank of England, and HM Treasury ... 47

\begin{tabular}{|c|c|}
\hline & \\
\hline 1. & Real Output and Its Major Components at Constant Factor Cost \\
\hline 2. & Labor Market Indicators . . . . . . . . . . . . \\
\hline 3. & Selected National Accounts Aggregates at 1990 Market Prices \\
\hline 4. & Selected Personal Sector Data $\ldots \ldots \ldots \ldots \ldots \ldots \ldots$ \\
\hline 5. & Components of Personal Income \\
\hline 6. & Selected Financial Statistics-Industrial and Commercial Companies \\
\hline 7. & Selected Inducators of Investment Activity $\ldots \ldots \ldots \ldots \ldots \ldots$ \\
\hline 8. & Selected Indicators of Wage Developments \\
\hline 9. & Selected Indicators of Price Developments \\
\hline 10. & Selected Balance of Payments Indicators . \\
\hline 11. & Merchandice Trade Indicators . . . . . . . . \\
\hline 12. & Exports by Commodity-Volume Indices \\
\hline 13 . & Imports by Commodity-Volume Indices \\
\hline 14. & Direction of Trade $\ldots \ldots \ldots \ldots \ldots \ldots$ \\
\hline 15. & $\ldots \ldots \ldots \ldots \ldots \ldots \ldots \ldots$ \\
\hline 16. & Capital Account ... \\
\hline 17. & General Government Accounts \\
\hline 18. & Nominal Exchange Rates \\
\hline 19. & Interest Rates \\
\hline 20. & Growth Rates of Selected Monetary Aggregates \\
\hline 21. & Contribution of Asset Counterparts to Growth in Broad Money Stock M4 \\
\hline
\end{tabular}




\section{United Kingdom: Basic Data}

\section{Demographic and other data:}

Area

Population (mid-1997)

Natural rate of increase (percent change at annual rate)

Infant mortality (per 1,000 live births)

Doctors per 1,000 inhabitants

GDP per capita (1997)

\section{Composition of GDP in 1997, at current prices}

Private consumption

Public consumption

Total investment (including stockbuilding)

Total domestic demand

Exports of goods and services

Imports of goods and services

GDP at market prices (average estimate)

Selected economic data

Output and unemployment:

Real GDP (at market prices, average estimate)

Manufacturing production

Average unemployment (in percent)

Earnings and prices:

Average earnings in manufacturing

Retail price index, excluding mortgage interest

Money and interest rates (end period):

MO

M4

3-month Interbank rate

10-year government bond yield

Fiscal accounts: $6 /$

General government receipts

General govermment expenditure excl.privatization

PSBR excl.privatization In percent of GDP

Balance of payments:

Current account balance

In percent of GDP

Trade balance

Exports

Imports

Services and transfers (net)

Direct investment (net)

Portfolio investment (net)

Short-term capital flows (net)

Gross reserves, official basis

(billions of $\mathrm{SDR}$, end of period)
94,247 square miles (244,100 square kilometers) 59.0 million

0.3
9.4
1.9
SDR 16,544

In billions

unds

500.6

147.4
133.7

Distribution

in Percent

784.8

62.5

18.4

16.7

98.0

228.7

28.5

801.1

100.0

801.1

100.0

1996

1997

1998

(Annual percent change)
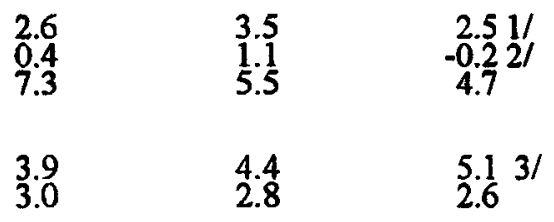

$\begin{array}{rrr}6.8 & 6.7 & 5.24 / \\ 9.6 & 11.7 & 8.64 / \\ 6.0 & 6.9 & 6.55 / \\ 7.8 & 7.0 & 4.55 /\end{array}$

(In billions of pounds sterling)

$\begin{array}{rrr}284.0 & 312.5 & 330.11 \\ 313.5 & 317.5 & 327.611 \\ 27.1 & 2.9 & -2.611 \\ 3.6 & 0.4 & -0.311\end{array}$

$\begin{array}{rrr}-1.8 & 4.5 & \ldots \\ -0.2 & 0.6 & \ldots \\ -12.7 & -13.0 & \ldots \\ 166.9 & 170.2 & \ldots \\ 179.6 & 183.1 & \ldots \\ 12.2 & \ldots & \ldots \\ 5.1 & -13.0 & \ldots \\ -30.2 & -20.3 & \ldots \\ 38.6 & \ldots & \ldots\end{array}$

$\begin{array}{llll}32.3 & 28.0 & 26.72 /\end{array}$

Sources: Office for National Statistics, Economic Trends and Financial Statistics; H.M. Treasury; and staff estimates. 1/ World Economic Outlook.

2/November 1998.

3/ July 1998.

4/ October 1998.

5/December 1998.

6/ Fiscal Year beginning April 1. 


\section{OPERATIONAL INDEPENDENCE AND THE CONDUCT OF MONETARY POLICY IN THE UNITED KINGDOM" ${ }^{1}$}

\section{A. Introduction}

1. Following the shift to inflation targeting in October 1992 and $4 \frac{1}{2}$ years of relatively successful experience with this regime, in May 1997 the U.K. authorities granted operational independence to the Bank of England. Under the new arrangement, the inflation target is set by the Chancellor of the Exchequer in the annual budget, and the Monetary Policy Committee (MPC)-established following the decision to grant independence, and consisting of Bank of England staff members and outsiders-sets interest rates to achieve the inflation target. ${ }^{2}$

2. This Chapter examines the impact of operational independence on the conduct of monetary policy in the United Kingdom. Section B describes the inflation targeting framework and the analytics of the decision making process. It suggests that inflation targeting, while not entirely new in terms of the basic idea, is a rather significant step toward establishing a workable and well-defined framework for monetary policy. It aims to be highly transparent in both the process and the result achieved by setting measurable objectives; by being explicit about the processes that link instruments with targets; and by specifying procedures for accountability. The Section also argues that while the framework retains the notion of medium-term rules - as advocated, for example, by the proponents of monetary targeting - to deal with inflationary bias in monetary policy, it nevertheless involves a partial return to the idea of explicitly attempting to stabilize major macro variables.

3. Section C discusses the potential benefits of independence relative to the 1992-97 inflation targeting framework. These largely result from a further reduction in inflationary bias inherent in a system where decisions may be excessively motivated by political consideration and a desire to use monetary policy to influence the short-term path of unemployment and output. The Section assesses the implications of independence from a theoretical point of view, and looks at the U.K. experience during the first year and a half the arrangement has been in operation. It concludes that independence will likely enhance the credibility and pricestability focus of monetary policy, and thus reduce inflationary bias.

4. Section D looks at independence and the issue of "gradualist" monetary policy. It is often argued that monetary policy suffers from excessive gradualism, in the sense that decision making seeks to smooth interest rates relative to some optimal policy rule. Operational independence has made decision making a more transparent, focussed, and analytical process. This could encourage activism and make monetary policy a less cautious process. On the

${ }^{1}$ Prepared by Jan Kees Martijn and Hossein Samiei.

${ }^{2}$ See Lane and Van Den Heuvel (1998) for a comprehensive description of the new regime. 
negative side, it is possible that, despite the two-year horizon, the new framework may encourage sharp changes in the interest rate-and give a distorted sense of transparency-by appearing to suggest that the MPC's monthly decisions are based only on information made available between two successive meetings. While it is too early to assess the evidence in this regard, there are examples which suggest that at least some MPC members favor a less gradualist approach to interest rate policy.

5. Section E examines how the new framework purports to enhance transparency in the monetary policy process. The system introduced in 1992 had already made substantial progress on that front by initiating the publication of the Quarterly Inflation Report and the minutes of the monetary policy meetings. Under the new framework, the Inflation Report presents the views of the MPC and the rationale for monetary policy decisions, as well as an assessment of developments and prospects. The minutes of the MPC meetings, including the members' votes, are published two weeks after the meetings. Moreover, there is a new element of accountability, whereby if inflation deviates by more than one percentage point in either direction from the target, the governor is required to explain the reasons in an open letter to the chancellor. This Section argues that while transparency has been strengthened in many respects, the framework, nevertheless, has some way to go before seriously testing the limits of transparency. In particular, the credibility of inflation forecasting has likely been weakened as a result of the transfer of decision making to the Bank, since the Inflation Report no longer presents an independent assessment of monetary policy decisions. It is possible that replacing the assumption of unchanged interest rates in the Inflation Report by a more realistic and explicit discussion of the likely future path of the interest rate-as, for example, practiced by the New Zealand Federal Reserve Bank-may strengthen the framework further.

6. Finally, Section $\mathbf{F}$ examines the implication of central bank independence on the fiscalmonetary policy mix. Most analyses of central bank independence do not take due account of the possibility that policy coordination may weaken, thus potentially offsetting the benefits of the lower inflation bias. At the same time when independence accompanies a general move toward more stable policies, as it seems to be the case in the United Kingdom, the impact on macroeconomic stabilization is likely to be positive. This Section argues that improved communication (including advanced announcement of the tax and expenditure measures that are likely to be included in the budget, as promoted by the new fiscal arrangements) would clearly help policy coordination. So would a more transparent approach to inflation forecasting by the Bank and its likely future interest rate policies.

\section{B. The U.K. Monetary Framework Since 1992}

7. The adoption of inflation targeting in October 1992 followed unsuccessful experiences with monetary targeting in the 1980 s and exchange rate targeting through ERM membership during early 1990s. Under the new arrangement the chancellor would make interest rate decisions, taking into account the governor's views in a systematic and explicit manner through monthly meetings on monetary policy. This was intended to lower the extent of politically-motivated inflation bias in economic policy. 
8. Following a period of ambiguity regarding the nature and the operation of the new system, which reflected the need for a speedy replacement of the abandoned exchange rate targeting framework, there was a gradual move toward a more precise inflation targeting framework. In particular, over time the inflation objective was modified from "a target range of 1-4 percent with the aim of being in the lower half in the medium term", to the relatively more precise rule of " 2.5 percent or less". An important feature of the framework has been increased transparency and accountability through the publication of Quarterly Inflation Report, which contains the Bank's inflation forecasts, and (starting in April 1994) the minutes of the monthly monetary policy meetings between the chancellor and the governor. This change in the institutional setup, which reflected a desire to enhance transparency, was also intended to mitigate the element of nontransparency introduced by the fact that 2-year ahead inflation (unlike current-period money growth or the exchange rate in the previous frameworks) was unobservable.

9. Inflation targeting, while not entirely new in terms of the basic idea, is a rather significant step toward establishing a workable and well-defined framework for monetary policy. It aims to be highly transparent in both the process and the result achieved by setting measurable objectives; by being explicit about the processes that link instruments with targets; and by specifying procedures for accountability. Thus it increases the weight the authorities attach to low inflation by strengthening accountability with respect to the public; and by following an explicit rule, contributes to enhancing credibility, strengthening the medium-term focus of monetary policy, and reducing inflationary bias in economic policy. ${ }^{3}$

10. While the framework retains the notion of medium-term rules for monetary policy, as advocated by the proponents of monetary targeting, it nevertheless involves a partial return to

${ }^{3}$ Arguments in favor of rules over discretion are typically based on the notion that monetary policy has an inherent bias in favor of inflation (Kydland and Prescott, 1977): policy makers have an incentive to exploit the difference between the short-run and the long-run trade off between inflation and unemployment through surprise inflation. Anticipating such policies, forward looking agents raise their expectations of the inflation rate in setting wages and prices, thwarting the ex post positive effect on output. Inflationary bias could also be associated with political business cycles or attempts to collect inflation tax. The relevance of the concept of an inflationary bias and the dominance of rules has been questioned on a number of grounds. First, in general pre-set rules would be inferior to discretion in the absence of bias arising from the institutional setup, as policy makers would always have the option of following the policies that a rule would prescribe. Second, to the extent that wages are adjusted at intervals shorter than the time it takes monetary policy to actually affect inflation, the credibility issue may not be significant (see Goodhart and Huang, 1998). Third, several observers have denounced the premise that the authorities, as a rule, aim for a level of output above its potential level, which creates surprise inflation (see Bean, 1998, Goodhart, 1998, Blinder, 1997). 
the idea of explicitly attempting to stabilize major macro variables. Monetary targeting's solution to the inflationary bias problem is based on the assumptions that a stable demand for money function exists and that inflation is a monetary phenomenon. Implicitly, this solution also aims to lower the political content of economic policy decision making by focussing on a variable that is not of immediate interest to politicians, thus in effect depoliticizing monetary policy (see von Hagen, 1995). Inflation targeting, by contrast, allows politicians to have an interest in monetary decisions, but compensates for it by strengthening transparency and accountability, in particular when accompanied by central bank independence.

11. The fact that inflation targeting uses expected inflation, as opposed to actual inflation, as an operational target (or as intermediate target, see Svensson, 1997) is significant. It implies that factors, such as the output gap and fiscal policy, that play a role in the determination of future inflation should in principle enter the decision making process, as well as the expectations of their future path and future interest rate decisions. For example, tight product and labor markets would be expected to raise inflation and within the inflation targeting framework, generate a monetary policy response even before actual inflation rose. Given the estimated lags between monetary policy and inflation, such forward looking behavior is necessary to achieve the target.

12. Despite obvious improvements in the operation of monetary policy, and the framework's apparent success in controlling inflation (see, for example, Lane and Van Den Heuvel, 1998), the new regime arguably did not include sufficient protection against the inflationary bias. The government remained in control of the policy process, and no institutional safeguards existed against the use of unsustainable politically motivated monetary policy decisions. ${ }^{4}$

13. In May 1997 the U.K. government took a crucial step to remedy this deficiency by giving operational independence to the Bank of England. Moreover, it adopted an explicit and symmetric point target of $2 \frac{1}{2}$ percent. The Monetary Policy Committee (MPC) was set up with the task of setting interest rates to pursue the inflation target. The forward-looking nature of the target is retained, but the two-year horizon is less explicit than in the 1992-97 framework. (Section $\mathrm{C}$ discusses the potential benefits of independence relative to the 1992-97 inflation targeting framework in terms of the inflationary bias.)

14. Under the new framework, the Inflation Report presents the views of MPC members and the rationale for monetary policy decisions, as well as an assessment of developments and

\footnotetext{
${ }^{4} \mathrm{~A}$ possible example is monetary policy during the last year of the previous government, when the Chancellor persistently declined to raise interest rates, despite recommendations by the Governor to the contrary. Of course, it is only with hindsight that one might be able to decide whether these were politically-motivated decisions or whether they were justified by economic prospects. See Lane and Samiei (1998), on monetary policy disagreements under the previous regime.
} 
prospects. The inflation Report presents projections for inflation and GDP over a two-year horizon in the form of fan charts. These charts reflect not only the diversity of views among the members, but also uncertainties involved in projections. ${ }^{5}$ The minutes of the MPC meetings, including the members' votes, are published two weeks after the meetings.

Moreover, there is a new element of accountability, whereby if inflation deviates by more than one percentage point in either direction from the target, the governor is required to explain the reasons in an open letter to the chancellor. Finally, there is a mechanism to ensure that the MPC uses all the relevant sectoral and regional information. ${ }^{6}$

15. The new framework has implicitly recognized that adopting a pure inflation target may limit the scope for macroeconomic stabilization, and that the goal of stabilizing prices should not be at the expense of excessive fluctuations in output. For, although, a long-run trade off between the levels of inflation and output may not exist, a trade off between the variability of output and the variability of inflation may. This holds especially in the case of supply disturbances, like an oil price shock, which affect output and inflation in opposing directions, implying that attempts to stabilize inflation would tend to amplify the output shock. Thus, inflation targeting might appear to pay insufficient attention to macroeconomic stabilization compared to, for example, nominal income targeting: following a positive supply shock, monetary policy would exert a further stimulus under inflation targeting, while nominal income targeting would imply the correct policy response.

16. The inflation targeting system in the U.K. has gone some way to deal with this problem. First, the focus on expected inflation, as noted earlier, requires that the policy authority should incorporate the behavior of other variables, including output, in its decisions, which helps in stabilizing demand shocks. This focus also mitigates the problem of supply shocks as the price effect of such shocks is likely incorporated fully within the two-year horizon (see Haldane 1997). Second, the new Bank of England remit stipulates that, without prejudice to the inflation target, the Monetary Policy Committee is expected to set interest rates so as to "support the general policies of the government, including its objectives for growth and employment". Since a particular inflation target can be achieved using different paths for the interest rate, output considerations can be allowed to determine which particular path is chosen. This allows for stabilization of output as a secondary objective.

17. Svensson (1997) defines "flexible" inflation targeting as aiming to achieve the inflation target but also minimizing the deviation of output from its natural or average level (given the existing distortion in the economy). A policy rule, consistent with this mandate, can be

\footnotetext{
${ }^{5}$ The Bank has not made available the model it uses for forecasting but it intends to do so in the near future. At the same time it has made it clear that off-model considerations contribute significantly to the forecasts.

${ }^{6}$ The Bank's non-executive members of Court are assigned the task of implementing an external evaluation of the MPC's performance in this regard (see the Bank's Annual Report).
} 
represented as resulting from minimizing a loss function that includes deviations of inflation from its target, as well as that of output from its natural rate in each period:

$$
L_{t}=\sum_{t=1}^{T} \rho^{t}\left[\left(\pi_{t}-\pi^{*}\right)^{2}+\lambda\left(y_{t}-y^{*}\right)^{2}\right]
$$

where $\rho$ is the discount rate, $y$ is output, and $y^{*}$ the natural level of output. It is important to note the asymmetry between inflation and output in this function: while inflation is desired to be close to its target, output is only forced to be close to its equilibrium level (which, in theory at least, does not require any policy action). Thus, in equilibrium the loss function is only determined by the deviation of inflation from its target, and such a rule would achieve the inflation target. Clearly to the extent that the output norm is set above the natural level of output, there will be an inflation bias in the system.

18. While "flexible" inflation targeting appears consistent with the Bank of England remit discussed earlier, it is not possible to be conclusive about this issue. Indeed, in practice it is difficult to distinguish "pure" from "flexible" inflation targeting when the system is subject to demand shocks, because the response of policy would be in the same direction under both rules. The scope to distinguish the two is larger in the presence of supply shocks, when the response of output and inflation are in the opposite directions. While, there are examples when the MPC appears to have responded to supply shocks in a way suggested by "flexible" targeting (for example, in relation to the impact of the introduction of the minimum wage and changes in taxation), the evidence is still rather tentative.

19. Finally, this representation of inflation targeting also suggests that its difference with other frameworks may be less real than apparent, and that the short-term operation of the monetary authorities under an inflation target may be indistinguishable from those operating under other rules. There is evidence that monetary policy decisions in different industrial countries may be approximated by similar rules (see Taylor, 1998). These so-called Taylor rules (which under other strong assumptions could be consistent with minimizing the above loss function relate the interest rate to its neutral rate $\left(r^{*}\right)$, and deviations of inflation from some target and of GDP from potential:

$$
i_{t}=r_{t}^{*}+\pi_{t}^{e}+w_{1}\left(\pi_{t}-\pi^{*}\right)+w_{2}\left(y_{t}-y^{*}\right)
$$


where $r^{*}$ is the neutral real rate of interest. ${ }^{7}$ Notwithstanding the estimation and interpretation problems associated with these rules, given the number of unobservable variables involved ${ }^{8}$, they provide some evidence that various monetary policy frameworks are likely to base their decisions on the same fundamental factors. What may distinguish them in practice, apart from performance, is how well the decisions makers incorporate latest information in their decisions, how depoliticized and independent the decisions are, and how transparent and accountable the decision making processes are.

\section{The Case for Central Bank Independence}

20. Central bank independence can increase the credibility of monetary policy by convincing private agents that the monetary authority has little incentive to create surprise inflation. In the case of political business cycles, the mere granting of central bank independence would likely suffice to remove the distortion. ${ }^{9}$ On the other hand, in case of a permanent inflation bias associated with time inconsistent policies, given that surprise inflation would be the equilibrium outcome, the mere introduction of central bank independence, without reference to its objective function, would not be a sufficient step. As demonstrated by Barro and Gordon (1983), a credible commitment to price stability would be required.

21. Several arrangements have been put forward to solve the problem of insufficient policy credibility, to which the new U.K. arrangement may be usefully compared.

\footnotetext{
${ }^{7}$ One set of estimates for the United Kingdom used frequently by the private sector sets $w_{1}$ and $\mathrm{w}_{2}$ equal to 0.5 -in effect, a nominal income target-and assumes the neutral rate of interest at 3.5 percent.
}

${ }^{8}$ It is also difficult to use them to draw conclusions regarding the appropriateness of a policy path ex post, because they are estimated using actual historical policy decisions. This is only partially remedied by the fact that in assessing the hypothetical performance of a particular rule, if applied in practice, independent criteria, for example in terms of the implied output variability, may be set (see for example Blake and Westaway, 1996).

${ }^{9}$ Moreover, to the extent that the policy shocks are not fully anticipated, removing these would also result in lower output variability. Surprise inflation linked to government elections could also result from uncertainty regarding the election outcome. As the inflationunemployment preference of a new government depends on this unknown outcome, with preset nominal wages based on expected inflation, real wages will turn out to be either higher or lower than their equilibrium level. In this setup, transferring monetary policy to an independent central bank would eliminate the policy uncertainty and the associated variability in inflation and output (Alesina and Gatti, 1995). 
- A monetary policy rule could be made mandatory. However, this approach would leave little scope for dealing with structural shifts (e.g., in money demand), and would likely hamper macroeconomic stabilization (see above).

- Rogoff (1985) proposed that society could rationally grant independence to a 'conservative central banker' with a higher inflation aversion than embodied in social preferences. This arrangement would leave the central bank the discretion to balance price and output stabilization. However, while the central banker's high degree of inflation aversion would limit the inflationary bias, output variability would remain higher than socially optimal.

- A central bank, that shares society's preferences on inflation and output behavior, could be given a target rate of inflation and an optimal incentive contract specifying its rewards for meeting it. In that way, a first best inflation-stabilization policy could be attained (Person and Tabellini, 1993; and Walsh, 1995). An equivalent but simpler solution to the incentive problem was provided by Svensson (1997): if the central bank is charged with attaining an inflation target that is below the socially optimal rate, its resulting objective could be identical to that resulting from an optimal performance contract.

22. Under a mandatory monetary rule, the central bank would not necessarily have independence, while under the second arrangement the conservative central banker would enjoy both goal independence and instrument independence- using Fischer's (1995) terminology. The third arrangement would give the central bank instrument independence only. Also, the implied accountability of the central bank in the latter case could help control the quality of policy makers (apart from their policy orientation).

23. Comparing the monetary policy framework since the 1997 introduction of instrument independence of the central bank to the proposals for optimal incentive contracts, it can be noted that no formalized reward structure has been introduced to ensure central bank compliance with the inflation target. But given considerable transparency and procedures to ensure accountability, it is likely to be a de facto incentive created for the monetary authorities not to deviate from the target. However, the inflation target itself, at $2 \frac{1}{2}$ percent, does not appear to have been set below the socially optimal rate- estimated by Fischer (1994) at between 1 and 3 percent.

24. Given the absence of a formal incentive structure, the arrangement also appears related to the model of a conservative central banker. Indeed, while the inflation target and the dominance of central bank representatives would serve to ensure its 'conservatism', the MPC is given some discretion in targeting low inflation while minimizing output instability, as discussed in the previous section.

25. In the proposals for optimal performance contracts for central banks, independence and inflation targeting are a natural union. In the United Kingdom, in the absence of such a 
contract, the combination has likely provided three improvements relative to the old system of inflation targeting without central independence.

26. First, as explained above, the MPC's focused accountability for reaching the inflation target, and the removal of electoral considerations from policy making, has limited the incentive to create surprise inflation.

27. Second, regardless of the actual presence of an inflation bias on the side of the policy makers under the previous regime, the clarity and credibility of the inflation target has likely been increased. Public monitoring of whether the authorities' inflation target deviates in practice from the announced target, is hampered by the fact that unobserved shocks could also cause observed inflation to deviate from the target. However, it appears likely that, given the MPC's clear remit and the professionalism of its members, the public would trust that the MPC bases it decisions on the official inflation target. This may have rendered the monitoring problem less relevant, strengthening the authorities' ability to credibly precommit to the inflation target.

28. Third, the clear focus of the MPC has allowed for a unique policy formation process, in which the actual policy-makers themselves produce an inflation forecast that provides the basis for the interest rate decision. With technical assistance provided by bank staff, the MPC determines all assumptions underlying the forecast, i.e., the future course of variables affecting inflation as well as the structure and parameters of the empirical models. Thus, all elements that will affect inflation over the relevant horizon are systematically and comprehensively analyzed and incorporated.

29. The first two of these advantages can explain the instant gain in credibility following the announcement of the new arrangement in May 1997, that can be inferred from interest rate developments. Expected inflation (measured as the differential between index-linked and non-indexed bond yields) declined by more than half a percentage point to about $31 / 2$ percent. $^{10}$

30. The new system could be subject to McCallum's (1995) general criticism of such arrangements that the credibility problem is relocated rather than solved. Just as the announcement of a rule would not be credible, private agents would recognize that the granting of central bank independence, or the official inflation target could also be revoked (McCallum, 1995). However, in practice, central bank independence would be harder to abolish (because it would require legal changes) than revoking the inflation target. In addition, the lags associated with monetary policy would ensure that, even if the political authorities altered the inflation target, actual inflation would not affect real wages within the period covered by existing (one-year) wage agreements. Thus, wage setters have no reason for anticipating such behavior.

\footnotetext{
${ }^{10}$ See also SM/97/256.
} 
31. Empirical evidence tends to provide qualified support in favor of the benefits of an independent central bank: independence appears to be associated with lower inflation, but causality is hard to confirm. ${ }^{11}$ It is, therefore, possible that independence and low inflation both have a common cause (for example increased public concern over the cost of price instability). Moreover, evidence does not seem to indicate a rise in output instability, as predicted by the conservative central banker model, and there is little evidence that independent central banks face lower output costs of disinflationary policies, in spite of their presumably higher credibility. ${ }^{12}$ Finally, there does not seem to be a correlation between political budgetary or monetary cycles and central bank independence (Posen, 1998).

32. These considerations indicate that, ceteris paribus, the new monetary arrangement would likely result in lower average inflation, without a destabilizing effect on output. This general conclusion leaves aside several issues concerning the actual conduct of monetary policy under the new arrangement. These questions will be addressed in the following sections.

\section{Gradualism in Monetary Decisions Making}

33. Historically, monetary policy in the United Kingdom appears to have been "gradualist", and the question arises as to whether the introduction of central bank independence is likely to change this practice. Policy has often involved a series of small interest rate changes in the same direction, and exhibiting particular caution in reversing the interest rate trend (see Goodhart, 1998). Between 1978 and 1998, the Bank's interest rate adjustments included 35 reversals to 112 continuations. Also, mechanical feedback rules do not fit actual policy well, unless a significant degree of interest rate smoothing is allowed for, suggesting further that monetary policy has tended to be gradualist. An alternative way of conceptualizing gradualism may be more relevant under inflation targeting. Gradualism could be defined as a less than full adjustment of interest rates given the objective of exactly reaching the inflation target in two years time. Full adjustment would require the interest rate to respond to all relevant unanticipated news.

34. Several explanations of such caution in changing the rate of interest have been proposed, with differing degrees of relevance to the United Kingdom.

- Gradual interest rate movements may be optimal given the dynamic structure of the economy, which is not captured well by standard policy feedback rules. In particular, given that the target variables exhibit a high degree of serial correlation, the existence

\footnotetext{
${ }^{11}$ See Eijffinger and de Haan (1996) for a survey of these studies.

${ }^{12}$ The latter hypothesis was tested by comparing the sacrifice ratios associated with disinflations for central banks with different degrees of independence. See Fischer (1996).
} 
of transmission lags implies that the optimal policy response will also consist of a series of steps in the same direction. ${ }^{13}$

- The Bank of England may seek to smooth interest rates because of concerns about financial sector stability. Given banks' traditional function in transforming short term liabilities into longer term assets, they may be vulnerable to unanticipated interest rate increases. $^{14}$

- A cautious monetary policy could be based on multiplicative uncertainty relating to the use of policy instruments. As first described by Brainard (1967), if policy makers are concerned about the variability of policy targets (in addition to the expected value), small steps are optimal if the effect of changes in a policy instrument is uncertain. For this conclusion it is assumed that higher uncertainty is attached to larger deviations from the current policy stance. Applied to monetary policy, the more sharply interest rates are adjusted to keep expected future inflation close to its target, the higher the resulting policy-induced inflation variability. This argument is all the more important given sizable policy lags which preclude a swift feedback. ${ }^{15}$

35. A further consideration combines the timing of private investments and interest rate anticipations in case of gradualist central bank behavior. In the case of predominantly fixed rates, forward looking investment behavior undermines the policy effectiveness. For example, in case of an initial decrease in interest rates to stem economic slowdown, investment could be postponed in order to benefit from expected further decreases that would make future investment more profitable. Moreover, as argued by Caplin and Leahy (1996), this phenomenon could give rise to a vicious circle, in which, first investors delay investment in anticipation of further interest cuts, and, second, the lack of investment indeed urges policymakers to provide these cuts. In case of flexible rate borrowing, on the other hand, private investment will adjust sharply following a policy reversal, as a large change in borrowing costs is anticipated, given that all investments will be refinanced at interest rates that are expected to continue to decline.

\footnotetext{
${ }^{13}$ See Sack (1998a) for an empirical analysis of this phenomenon for the US.

${ }^{14}$ See Cukierman (1992), pp. 117-129.

${ }^{15}$ The latter argument has been developed further by Sack (1998b), to explain a policy of interest rate smoothing. With every step, the monetary authority gains insight into the interest rate effect at the new level. The reduced uncertainty allows it to move further. It also follows that after a period of relatively large interest rate changes, new shock can be met with larger interest rate adjustments, as recent information is still available on the effects of a range of interest rates.
} 
36. A crucial question is whether there is excessive caution after taking into account all legitimate aspects of optimal policy formation. For the United Kingdom there has little empirical research that would shed light on this issue.

37. If, as has been argued by, for example, Goodhart (1998) the Bank of England's actions include excessive caution, the further question arises of how the changed institutional framework will affect this pattern. Goodhart expects central bank independence to lead to a more aggressive policy approach, presenting some preliminary evidence. Such change would reflect the Bank's focus on the inflation target, and its more analytical (as opposed to political) approach. A further consideration may be that the separation of prudential supervision, which has been delegated to the Financial Services Authority, and monetary policy may limit the degree to which concern about financial sector soundness serves as a motive for interest rate smoothing. A final consideration is that MPC behavior is the result of the dynamics of majority voting within the committee, with views diverging among the members. The public voting record to date indicates that some members appear to be less gradualist than others. One implication is that a small change in membership could have a relatively large effect on policy.

\section{E. Transparency in the New Framework}

38. An important feature of the new monetary policy framework is increased transparency, in particular through the quarterly Inflation Report and the minutes of the monetary policy meetings. Transparency of the MPC's goals and achievements is a precondition for accountability, which, in turn, serves to discipline MPC behavior and may also be considered essential in ensuring its political legitimacy. In addition, transparency can also help enhance policy credibility. Given the absence of a track record of policy achievements, transparency of the policy-making process may serve as a substitute in convincing the public of the MPC's intentions and competency.

39. At the same time, however, while the focus on inflation forecasting has imposed accountability and discipline on individual members of the MPC, it may have weakened the credibility of the forecasts as presented in the Inflation Report. During the 1992-97 inflation targeting framework, the Bank, in effect, acted as an advisor to the government on monetary policy decisions, and presented independent forecasts. Since the MPC took over the job of monetary policy decision making, the analysis and the inflation forecasts reported in the Inflation Report cannot be treated as those of an independent reviewer: the body that makes interest rate decisions also assesses these decisions. As a result, it would be difficult to envisage a situation where the forecasts suggest that the two-year ahead inflation, on which public scrutiny tends to focus, would (in probabilistic terms) be missed, because then the report would in fact be questioning the committee's own policy decisions. Indeed, since the Bank became independent, two-year ahead inflation has always been around the target. While this is possible logically, it raises questions as to the credibility of the Bank's inflation forecast. 
40. The problem is compounded by the Bank's decision not to present an assessment of the likely future path of the interest rate. Instead, its primary inflation forecasts are made under the explicit assumption of unchanged interest rates. In principle, there are many interest rate profiles that could deliver an inflation of 2.5 percent two years ahead. Clearly, and as discussed in the previous section, there is no reason to suppose that a policy that holds interest rates unchanged and delivers a two-year ahead inflation of 2.5 percent is necessarily superior to other policies.

41. The Inflation Report, therefore, appears to lack transparency and credibility in relation to its inflation forecast. It is not obvious to what extent the inflation forecast based on constant interest rates is a expositional or an operational construct. If it is the latter, the MPC indeed does not intend to smooth interest rates, and consistently expects to hit the target at the newly set rate. In that case the framework is transparent, but, given a history of interest rate smoothing, it is not considered credible by market participants, as is evidenced by the deviating market forecasts. On the other hand, if the MPC considers that further interest changes are likely to be necessary, even in the absence of news, the framework lacks transparency as well. In defense of the constant interest rate assumption it has been argued that the setup provides a clear benchmark that allows an evaluation of the direction of policy changes (Haldane, 1997)

42. One possible solution to the loss of transparency would be for the Bank to publish its own interest rate projections, possibly based on some standard policy reaction function, and include these in its projections of inflation. To prevent suggesting an unwarranted degree of accuracy, and in line with the uncertainty pertaining to the course of inflation and output, interest rate projections could be presented in a fan chart. Presenting an interest rate projection would be similar to the approach adopted by the Federal Reserve Bank of New Zealand, which publishes a projection of a monetary conditions index that includes both interest rates and the exchange rate path. Obviously, the Bank would have to make it clear that it was not committing itself to a particular path, so that without loss of credibility it might revise its projection at a later date as new information becomes available. The Bank could also include outside projections of inflation in the Inflation Report. The MPC could assess any differences between its own and these outside projections, with reference to, for example, differing assumptions on the course of interest rates.

43. It is important to consider the possible effects of publishing an interest rate projection on private sector behavior. Private agents already have expectations concerning the future course of interest rates, and information provided by the central bank already constitutes an important input to these projections. More explicit central bank information may alter private sector interest rate expectations, and may, in particular, diminish the subjective uncertainty with which expectations are held, and thus diminish the risk premium. Also, the availability of more information is likely to diminish expectational errors and the deadweight losses related to economic decisions based upon such errors. The argument here is basically similar to that against central bank secrecy in general (see Briault, Haldane, and King, 1996). The danger is that the private sector, by anticipating official interest rate movements, may cause adjustments 
in market interest rates ahead of the official change, thus limiting the Bank's ability to execute a gradualist monetary policy. Also if a series of interest rates decreases is foreseen, investors may postpone new investments, undermining policy effectiveness and destabilizing the economy. While, the issue clearly requires further investigation, the experience of New Zealand does not appear to support the empirical relevance of the latter argument.

\section{F. Independence and Optimal Policy Mix}

44. A fundamental implication of central bank independence is the separation of monetary and fiscal policies, with a virtually unavoidable impact on the policy mix. Most analyses of central bank independence, as discussed above, do not take due account of the possibility that policy coordination may weaken, thus potentially offsetting the benefits of the lower inflation bias. At the same time when independence accompanies a general move toward more stable policies the overall impact on macroeconomic stabilization is more likely to be positive. The issue has gained increased significance in recent years as the United Kingdom has not only adopted a more stability-oriented monetary policy, including central bank independence, but has also moved toward a more rules-based fiscal policy. While both objectives may be worthwhile in their own right, as they strengthen policy discipline, given the interaction between the two policies, in particular as far as macroeconomic management is concerned, the question can be raised as to whether the new arrangement can deliver a desirable policy mix.

45. Given the interactions of fiscal and monetary policy, a clear case can be made in favor of policy coordination. ${ }^{16}$ Specific connections between fiscal and monetary policies are:

- Monetary and fiscal policy can be seen as substitutes for short-term macroeconomic stabilization, albeit with different inflation and contrasting exchange rate repercussions.

- As a corollary, the optimal monetary policy rule-which reflects the trade off between the variability of output and inflation-likely depends on the degree to which fiscal policy is also used for countercyclical stabilization-either discretionary or through automatic stabilizers.

- An increase in official interest rates, will induce an increase in the government's debt service costs-at least in nominal terms.

- An increase in taxes will affect inflation. For indirect taxes, the direction of this effect depends on whether the demand or the supply effect of the tax increase dominates. For direct taxes, an increases in taxes may affect inflation, if it becomes built into wages and subsequently validated by monetary expansion.

- Government spending can partly be financed through an inflation tax.

\footnotetext{
${ }^{16}$ See Laurens and de la Piedra (1998).
} 
46. If the central bank is independent, the resulting policy game depends on the institutional setup. In the literature, it is generally assumed that, compared to the fiscal authority, the monetary authority attaches more weight to the inflation target and less to the output target and government spending. In the United Kingdom this is, indeed, likely given the bank's responsibility for meeting the inflation target.

47. Although, in these policy games, central bank independence reduces the inflation bias (see Box 1), the effect on overall welfare is not unambiguous. Generally, the reduction in the inflation bias has to be balanced against the disadvantages of the absence of coordination. Also, in a dynamic game setting, the interaction between the authorities could, given their differing objectives and information sets, result in policy conflicts, blocking strategies, and system instability. ${ }^{17}$ A result derived by Blake and Weale (1998) is that if the two policy makers are misinformed about each others intentions, no stable equilibrium may be reached.

48. Applying the above considerations to the United Kingdom, a first observation is that experience before 1997 shows that having both policy instruments under the control of the government provides no guarantee of effective policy coordination.

49. Under the current policy rules, both fiscal and monetary policy have an explicit and appropriate medium term focus. The absence of attempts towards fine-tuning limits the need for day-to-day policy coordination. Also, credible policies aimed at price stabilization and sustainable public finances are likely to foster private sector confidence and resilience to economic shocks.

50. Furthermore, within the new framework, policy coordination is fostered through the Treasury's (non voting) representative in the Monetary Policy Committee. More generally, the Treasury has publicly emphasized that fiscal policy should support monetary policy in promoting stability, adding that in the current cycle, monetary and fiscal policy were tightened together to slow the economy. ${ }^{18}$

51. Notwithstanding the above considerations, there are still several features of the new regime that may impair effective policy coordination.

\footnotetext{
${ }^{17}$ See Hughes Hallet and Petit (1990).

${ }^{18}$ H.M. Treasury (1998).
} 


\section{Box 1. Policy Games with Central bank Independence}

Consider a policy game between an independent central bank setting monetary policy (in some cases simplified by assuming it sets the rate of inflation) and the fiscal authority determining government spending. Both players seek to maximize a quadratic objective function that includes an inflation and an output target, and for the fiscal authorities, also a spending target. The central bank attaches relatively larger weight to price stability. Some fairly general results are (assuming a one-shot game between the monetary and fiscal authorities):

- Central bank independence will limit the inflationary bias and the degree to which government spending is financed through an inflation tax (see Alesina and Tabellini, 1987). However, if the overall tax distortion increases as a result, output will be lower than without independence. If the independent central bank can credibly commit to an inflation target, the inflation bias is fully eliminated, and inflation, output, and government spending are reduced further.

- $\quad$ Adding the option of debt financing of government spending results in a more ambiguous outcome. The government could then decide to accumulate more debt; a move that would encourage the central bank to create more inflation in the future-in accordance with the fiscal authorities' preferences. The intuition behind this result is that the resulting increase in future debt servicing costs would raise government spending, implying a larger tax distortion: The resulting output loss would strengthen the monetary authority's incentive to create surprise inflation (See Beetsma and Bovenberg, 1997; inflation could be boosted further by the possibility of using an inflation tax to limit the tax distortion).

- Only if the monetary authority attached no weight to the output objective, would inflation be unaffected by the fiscal authority (see Fischer and Debelle, 1994, and Debelle, 1996).

Although an independent central bank could not directly prevent a political cycle in fiscal policy, a refusal to accommodate the fiscal deficit might still act as a constraint.

Fischer and Debelle (1994) showed that if the budget process allows the fiscal authority to precommit to a spending level in advance, while monetary policy is determined afterwards, the fiscal authority could act as a Stackelberg leader, which would result in higher government spending and inflation. On the other hand, central bank independence combined with a fixed inflation target that remains in place during several budget cycles, could give the monetary authority the leading position. In their model, this would likely result in a lower rate of inflation. 
- The nature of the "policy game" is not yet clear. On the one hand, the yearly determination by the Chancellor of the inflation target and the more frequent decisions on monetary policy tend to put the government in a leading position. On the other hand, in practice the inflation target is unlikely to be adjusted and given its independence, the central bank could decide to ignore the government's preferences, and, for example, decide to offset a fiscal stimulus, to the extent that it considers it inflationary, despite the potentially sharp exchange rate effect.

- The Bank and the Treasury may develop different views of economic development and, therefore, of future inflation, thus possibly ending up working at cross purposes.

- The new rules for fiscal policy are likely to affect the degree of automatic fiscal stabilization. Given that fiscal policy tends to affect aggregate output more rapidly than changes in official interest rates, this uncertainty complicates forward looking monetary policy.

- Policy makers' strategies under the current framework are still unclear. In particular, there is still considerable uncertainty on the different policy stances of the members of the MPC, and on their strategic interaction.

52. Given the evident historical inflation bias in the United Kingdom, and often poor policy coordination, the potential drawbacks of decoupling monetary from fiscal policy making should not be overrated. The above-mentioned uncertainties are likely to be resolved over time, as policy practices are established based on the new framework, and policy makers gain understanding of each others strategies. While, there appears no urgent reason for concern about the adequacy of policy coordination under the new regime, improved communication (including the advanced announcement of the tax and expenditure measures that are likely to be included in the budget, as promoted by the new fiscal arrangements) would clearly help policy coordination. Moreover, more transparent approach to inflation forecasting by the Bank and its likely future interest rate policies would help the fiscal authorities in determining the extent that fiscal policy needs to be used for macroeconomic management.

\section{G. Concluding Remarks}

53. The main conclusion of this Chapter is that inflation targeting combined with operational independence of the central bank, as exists in the United Kingdom since May 1997, provides a suitable framework for a focused and credible monetary policy that is effective in reducing the inflationary bias in policy making. The framework is also noteworthy in that it incorporates features that are in line with evolving views on best practices, and which, therefore, have not yet been subject to significant empirical scrutiny.

54. Several potential weaknesses- although probably of minor importance-of the new system have been identified in this Chapter. First, it is important to ensure that the inflation 
target is achieved without excessive output variability. This issue has been broadly addressed through the MPC's remit, and its focus on inflation over a longer horizon. Second, inflation projections based on unchanged interest rates over the two-year horizon, as presented in the Inflation Report, lack transparency and credibility, and, if taken literally, may require changes in policy interest rates in the current period that are unduly sharp. The MPC could become more up-front about the likely future course of interest rates. While such approach would test the limits of transparency, experience in New Zealand suggests it may well be feasible. Third, dividing the responsibility for fiscal and monetary policy could reduce policy coordination. However, given the record on policy coordination, the new partly rules-based framework is likely to be an improvement in promoting overall macroeconomic stability. Still, adequate exchange of information between the Chancellor and the Bank of England is of importance in this respect. 


\section{REFERENCES}

A. Alesina and G. Tabellini, 1987, 'Rules and discretion with Noncoordinated Monetary and Fiscal Policies,' Economic Inquiry, Vol. pp. 619-630.

A. Alesina, and R. Gatti, 1995, 'Independent Central Banks: Low Inflation at no Costs,' American Economic Review, Papers and Proceedings, Vol.85, pp. 196-200.

R.J. Barro, and D.B. Gordon, 1983, 'A Positive Theory of Monetary Policy in a Natural Rate Model,' Journal of Political Economy, Vol. 91, pp.589-610.

C. Bean, 1998, 'The New UK Monetary Arrangement: A View from the Literature,' Paper presented to the Academic Panel of H.M. Treasury, Centre for Economic Performance, London School of Economics, (March).

R.M.W.J. Beetsma and A.L. Bovenberg, 1997, 'Central Bank Independence and Public Debt Policy,' Journal of Economic Dynamics and Control, Vol.21, pp 873-894

A.P. Blake and M. Weale, 1998, 'Costs of Separating Budgetary Policy from Control of Inflation: A Neglected Aspect of Central Bank Independence,' Oxford Economic Papers, Vol.50, pp.449-467.

Blinder, Central banking in Theory and Practice, Cambridge, Mass., 1998.

W. Brainard, 1967, 'Uncertainty and the Effectiveness of Policy,' American Economic Review, Papers and Proceedings, Vol.57, pp. 411-425.

C.B. Briault, A.G. Haldane, and M.A. King, 1996, 'Independence and Accountability, Bank of England Working Paper, No. 49.

A. Caplin and J. Leahy, 1996, 'Monetary Policy as a Process of Search,' American Economic Review, Vol. 86, pp. 689-702.

A. Cukierman, 1992, Central Bank Strategy, Credibility, and Independence: Theory and Evidence, Cambridge mass..

G. Debelle, 1996, 'Central bank Independence: A Free Lunch?,' IMF Working Paper 96/1 (Washington: International Monetary Fund).

G. Debelle and S. Fischer, 1994, 'How Independent should a Central Bank Be?,' in:

J.C. Fuhrer (ed.), Goals, Guidelines, and Constraints Facing Monetary policy Makers, Federal Reserve bank of Boston Conference Series, No. 38. 
S. Fischer, 1995, 'Modern Central Banking,' in: F. Capie, S. Fischer, C.E.A. Goodhart, and N. Schnadt (eds.), The Future of Central banking, Cambridge.

A.M. Fischer, 1996, 'Central bank Independence and Sacrifice Ratios,' Open Economies Review, Vol.7, pp.5-18.

A. Hughes Hallett and M.L. Petit, 1990, 'Cohabitation or Forced Marriage? A Study of the Costs of Failing to Coordinate Fiscal and Monetary Policies,' Weltwirtschaftliches Archiv, Vol. 26, pp. 662-690.

C.A.E. Goodhart, 1996, 'Why do the Monetary authorities Smooth Interest Rates?,' Chapter 8 in: S. Collignon (ed.), European Monetary Policy, London.

C.A.E Goodhart, 1998, Central Bankers and Uncertainty.

C.A.E Goodhart and H. Huang, 1998, 'Time inconsistency in a Model with Lags, Persistence, and Overlapping wage Contracts,' Oxford Economic Papers, Vol.50, pp.378-398..

A.G. Haldane, 1997, 'Some Issues in Inflation Targeting,' Bank of England Working Paper.

King, 1997, 'The Inflation Target Five Years on,' Bank of England Quarterly Bulletin, Vol.37, pp.434-442.

F.E. Kydland, and E.C. Prescott, 1977, 'Rules rather than Discretion: The Inconsistency of Optimal Plans,' Journal of Political Economy, Vol.85, pp. 473-491.

B. Laurens and E.G. de la Piedra, 1998, 'Coordination of Monetary and Fiscal Policies,' MMF Working Paper 98/25 (Washington: International Monetary Fund).

B.T. McCallum, 1995, 'Two Fallacies Concerning Central Bank Independence,' American Economic Review, Papers and Proceedings, Vol.85, pp. 207-211.

T. Persson, and g. Tabellini, 1993, 'Designing Institutions for Monetary Stability,' CarnegieRochester Conference Series on Public Policy, Vol. 39, pp. 53-84.

A. Posen, 1998, 'Central bank independence and Disinflationary Credibility: A Missing Link,' Oxford Economic Papers, Vol.50, pp.335-359.

K. Rogoff, 1985, 'The Optimal Degree of Commitment to an Intermediate Monetary Target,' Quarterly Journal of Economics, Vol. 100, pp. 1169-1190.

B. Sack, 1998a 'Does the FED act Gradually? A VAR Analysis,' Finance and Economics Discussion Series, No.1998-17, Board of Governors of the Federal Reserve System, Washington, D.C. 
—_, 1998b, 'Uncertainty, Learning, and Gradual Monetary Policy,' Finance and Economics Discussion Series, No.1998-34, Board of Governors of the Federal Reserve System, Washington, D.C.

L.E.O., Svensson, 1997, 'Inflation Targetting: Implementing and Monitoring Inflation targets,' European Economic Review, Vol. , pp.1111-1146.

Taylor, J. B. Ed., 1998, Monetary Policy Rules (Chicago University Press, Chicago), forthcoming.

H.M. Treasury, 1998, "Delivering Economic Stability: Lessons from Macroeconomic Policy Experience", (November).

Von Hagen, J., 1995, "Inflation and monetary targeting in Germany", in L. Leiderman and L. E. O. Svensson, eds., Inflation Targets (CEPR, London).

C. Walsh, 1995, 'Optimal Contracts for Central Bankers,' American Economic Review, Vol.85, pp. 150-167. 


\section{The Financial Services Authority: Structure, MANDATE, AND Policy IsSUEs ${ }^{19}$}

\section{A. Introduction}

55. The evolution of the U.K.'s financial markets during the last decade, concerns with consumer protection, and popular perception of weakness in supervision after a number of financial scandals since the early-1990s, led the U.K. government to establish a new framework for financial regulation in the Summer of 1998, with legislation to be completed over the course of the next two years. The new regulatory framework takes stock of the supervisory experience of industrial countries during the last decade and incorporates many innovations that are likely to enhance the stability of the U.K.'s financial system with respect to the pre-reform regime. It will also improve the focus and transparency of both monetary policy and financial supervision. Greater transparency of supervisory practices, greater accountability of supervisors, and strong emphasis on consumer protection are the major achievements of the new framework. The new framework emphasizes the need to consolidate supervisory responsibilities to overcome the fragmented structure of the pre-existing regime and the progressive undermining of traditional barriers between different financial activities, and emphasizes the shift to a single regulator of financial markets-the Financial Services Authority (FSA) - as the best response to this evolution.

56. This paper reviews the regulatory framework being established in the U.K. with the creation of the FSA, and discusses its main features in light of the challenges posed by regulation of a developed and internationally integrated financial system such as the U.K. 's.

\section{B. The FSA's Main Regulatory Responsibilities}

57. The Financial Services Authority (FSA) came into existence on October 28, 1997, as the prospective single regulator for all U.K. financial markets. It replaced the Securities and Investments Board (SIB), following Chancellor Brown's May 20, 1997 announcement that a single entity would be created, to merge responsibilities for financial supervision previously dispersed among nine regulatory bodies. ${ }^{20}$ Under the Bank of England Act 1998, which came

\footnotetext{
${ }^{19}$ Prepared by Leonardo Bartolini.

${ }^{20}$ These include the Building Societies Commission (regulating building societies), the Friendly Societies Commission (friendly societies), the Insurance Directorate of HM Treasury (insurance companies), the Registry of Friendly Societies (credit unions), the Securities and Investments Board (investment business), the Supervision and Surveillance Division of the Bank of England (banks and wholesale money market), and the three Self-Regulating Organizations: the Investment Management Regulatory Organization (IMRO; regulating investment funds), the Personal Investment Authority (PIA; retail investment business), and
} 
into force on June 1, 1998, the FSA took over banking supervision responsibilities from the Bank of England (BoE), an action which involved the transfer of about 500 supervisory staff from the BoE to the FSA. At the same time, the FSA also took over most of the staff of the three Self-Regulating Organizations (SROs), and began to supply regulatory services under contract to these bodies, whose Boards will retain legal responsibility for investment business supervision until their eventual abolishment. Pending approval of the legislation supporting the regulatory reform, the remaining staff of the SROs and of the other regulatory bodies are also being transferred to the FSA. ${ }^{21}$

58. The FSA is a private company, with assigned statutory powers, financed by levies on the financial services industry. Its Board is appointed by the Chancellor of the Exchequer and currently consists of an executive Chairman, two Managing Directors, nine non-executive Directors, and the Deputy Governor (Financial Stability) of the Bank of England. The primary objectives of the FSA in its role as financial services supervisor is to promote the safety and soundness of U.K. financial businesses and to strengthen the protection of investors. ${ }^{22}$ The basic principle under which the FSA operates is that financial businesses' inability to service their obligations should be made a remote - but not impossible - event. The linchpin of this mandate is represented by a system of authorizations, allowing no one to engage in professional provision of financial services in the U.K. without authorization by the FSA.

\footnotetext{
${ }^{20}$ (...continued)

the Securities and Futures Authority (SFA; securities and derivatives business).
}

${ }^{21}$ Although the SIB was renamed the FSA in October 1997, the legal status and operations of the various regulatory bodies did not change until the coming in force of the Bank of England Act 1998. At that point, the FSA took responsibility for banking supervision and began to perform the functions attributed to the SIB by the Financial Services Act 1986. The Financial Services and Markets Bill, a draft of which was published for public consultation in July 1998, will repeal the Financial Services Act and integrate it with existing legislation, including four more extensive Acts devoted to financial regulation: the Insurance Companies Act 1982, the Banking Act 1987, the Building Societies Act 1986, and the Friendly Society Act 1992. The Bill should be introduced into parliamentary debate in 1999, be approved by Parliament in early-2000, and become fully effective later in that year.

${ }^{22}$ The draft Financial Services and Markets Bill articulates these broad goals into four items: to maintain confidence in the U.K. financial system, to promote public understanding of the financial system, to protect consumers of financial services, and to reduce financial crime. These goals emphatically include the FSA's responsibility for setting conduct of business requirements in pursuit of consumer protection, a major mandate of the FSA which is discussed later in this paper. 
59. To be (and remain) authorized, financial services firms must satisfy a set of requirements, including that the business be properly equipped to carry out financial activity and that it satisfies prudential capital requirements. Details of these requirements will be spelled out in the FSA's Handbook. However, the existing and proposed body of legislation, as well as past supervisory practice, provide a clear picture of the regulatory structure to prevail after re-drafting and final approval of the Financial Services and Markets Bill.

60. The FSA's first check on authorized firms will be at their entrance point. To become authorized, a firm must convince the FSA that it is "fit and proper" to perform its business and to have a realistic business plan and adequate "systems and controls." The FSA has published its preliminary interpretation of these terms (see FSA, 1998d). The language of existing and proposed legislation, with its emphasis on "integrity," "prudence," and "fairness," on the part of businesses' management is rather vague. This is intentionally so, however, in keeping with the tradition of existing Acts, and to satisfy regulators' need for discretion when assessing the opportunity to deny or revoke a licence in contingencies that are too difficult to define in detail a priori.

61. Prudential supervision of authorized institutions is to be carried out by the FSA in accordance with a number of EU directives in the area of financial services, all of which have been implemented in the U.K. Most recently, the EU's Capital Adequacy Directive (CAD) and CAD II (implemented in the U.K. on January 1, 1996, and on September 30, 1998, respectively) have extended the U.K. supervisory picture to cover market risk and have provided scope for internal value-at-risk (VaR) models to determine risk capital. ${ }^{23}$ Importantly, U.K. regulators retain significant flexibility with respect to these and other internationally agreed standards. For instance, they typically set capital ratios above the Basle Accord guideline of a minimum of 8 percent; they also set required capital ratios in firmspecific fashion, taking into account credit and market risk factors specific to a firm's business, and apply them on a consolidated basis to all financial firms within a group.

${ }^{23} \mathrm{VaR}$ models calculate risk exposure by computing probabilities of financial assets' price movements based on past price changes. The institution is then asked to set aside sufficient capital to cover losses arising in, typically, 95 percent or 99 percent of holding periods of predetermined length (say, ten days). By recognizing the presence of multiple risk factors contributing to the overall riskiness of an institution's portfolio, and the risk-reducing implications of portfolio diversification, VaR models typically allow savings on capital requirements with respect to the traditional "building-block" methodology, which simply adds capital requirements over a number of separate activities. (See Jackson and Perraudin, 1998, for an introduction to $\mathrm{VaR}$ models and a discussion of their application by the $\mathrm{BoE}$.). Currently, four institutions subject to prudential supervision by the FSA have their internal risk-management models recognized by the FSA for use in calculating regulatory capital for market risk (many more institutions are on their way to do so). Reportedly, this approach has delivered fairly successful overall capital requirements while maintaining adequate provision against risk. 
Prudential requirements for authorized firms also involve limits on maximum exposure toward single (or related groups of) counter-parties; liquidity requirements, aimed at securing an institution's access to enough cash and high-quality near-cash assets to meet its obligations; and provisioning for 'bad' and 'doubtful' debts. To ensure compliance with FSA requirements, each authorized firm employs accountants to report periodically on the firm's operations, on its adherence to the FSA's guidelines, and on potentially worrying financial developments, such as sharp changes in the firm's exposure to individual sectors or countries. Teams of FSA staff and professional auditors also review periodically authorized firms' operations to monitor compliance.

62. The FSA is also responsible for supervising authorized firms' ongoing dealing with investors; for facilitating the resolution of complaints against authorized firms; for dealing with violations of the rules, including possible imposition of fines and revoking of authorization; and for pursuing market abuses and criminal activities, to the point of possibly seeking criminal proceedings against offenders.

63. This regulatory regime will encompass a wide variety of financial services firms. First, it will apply to about 350 of the over 600 banks authorized to collect deposits in the U.K. ${ }^{24}$ It will also apply to about 6,300 investment businesses (currently under formal control of the SROs) and to about 16,000 firms whose main activity is not business investment, but have some minor involvement therein (currently regulated by the eight "Recognized Professional Bodies"25). The FSA will also supervise: the six recognized investment exchanges (the London Stock Exchange, Tradepoint Stock Exchange, the London International Financial Futures and Options Exchange, the London Securities and Derivatives Exchange Ltd., the International Petroleum Exchange of London Ltd., and the London Metal Exchange); the two recognized clearing houses, the London Clearing House and CrestCo., which organize the

${ }^{24}$ These institutions include both U.K. -incorporated banks, as well as non-European Economic Area banks, which must be authorized by the FSA. The remaining 250 banks are branches of institutions incorporated in the European Economic Area (the EU, plus Norway, Iceland, and Liechtenstein) and are therefore authorized and supervised by their home states. (For the latter banks, the FSA's responsibility is limited to supervising the liquidity of the EEA branches in cooperation with the home state authorities.) This regime of 'home country control' is codified in the EU's Second Banking Co-ordination Directive of 1993, and parallels a similar regime for investment businesses, codified in the EU's Investment Services Directive, and insurance, codified in the EU's Third Life and Non-Life Directives.

${ }^{25}$ These are: the Association of Chartered Certified Accountants, the Institute of Actuaries, the Institute of Chartered Accountants in England and Wales, the Institute of Chartered Accountants in Scotland, the Institute of Chartered Accountants in Ireland, the Law Society, the Law Society of Northern Ireland, and the Law Society of Scotland. A ninth body, the Insurance Brokers Registration Council, is currently being wound-up, and remains in charge only to complete some outstanding disciplinary tasks. 
settlement of transactions on the recognized investment exchanges; and ECHO, the clearing house for foreign exchange spot and forward contracts. ${ }^{26}$ The FSA will also supervise wholesale markets in over-the-counter derivatives, ${ }^{27}$ and the insurance market, responsibility for which is being transferred from the Insurance Directorate of HM Treasury, along with new expanded powers with respect to Lloyd's. ${ }^{28,29}$ The supervisory role of the FSA as regards foreign currency and bullion remains to be clarified.

64. Finally, the FSA will establish a new single Financial Services Ombudsman to receive and handle consumer complaints. It will also merge the existing five compensation schemes

${ }^{26}$ Maintaining the approach of the current legislation, such bodies will remain exempt from FSA authorization, will not be subject to business conduct rules, and will be granted immunity from civil action by their members for actions taken with respect to their regulatory functions. However, in order to maintain this status, they must meet certain requirements, including having adequate financial resources, appropriate rules for their members, and effective monitoring and enforcement arrangements. More generally, they must convince the FSA that trading on the markets they organize is conducted in an orderly manner and affords proper protection to investors. Furthermore, the FSA will receive broad powers with respect to these bodies - in particular, it will be able to direct them to take corrective actions if it becomes dissatisfied with the way they fulfil the recognition criteria.

${ }^{27}$ The regulatory regime and business standards for these markets are currently contained in the Grey Paper and the London Code of Conduct of 1995. Institutions listed under the Grey Paper are currently exempted from authorization requirements of the Financial Services Act 1986 but the new regime will eliminate this exemption, requiring FSA authorization for these firms.

${ }^{28}$ The Lloyd's insurance market enjoys special treatment in recognition of its importance for the U.K. financial services industry. Even after complete establishment of the FSA, many aspects of Lloyd's business will continue to be self-regulated by the Lloyd's governing body, the Council, under powers conferred to it by the Lloyd's Acts 1871-1982. However, the Financial Services and Markets Bill will bring more uniformity between the regulation of Lloyd's and other insurers, by assigning the FSA powers to authorize the Society of Lloyd's, Lloyd's managing agents, and Lloyd's members' agents, as well as extensive powers of investigation, intervention, and discipline. Generally, however, the FSA will attempt to refrain itself from using these powers, as long as it sees Lloyd's as regulating itself satisfactorily.

${ }^{29}$ Another exception to integrated regulation is provided by mortgage products. Although building societies are subject to prudential regulation, they and other mortgage intermediaries have an opportunity to demonstrate that the Council of Mortgage Lenders' code of conduct is sufficient to protect the interests of consumers. However, the Government intends to keep under review the case for superseding this code and, if this is not seen as working satisfactorily, for assigning new powers to the FSA with regard to this market. 
into a new, single compensation scheme, the Financial Services and Markets Compensation Scheme, whose aim is to partially safeguard consumers of financial services against failure of authorized institutions to deliver on their obligations. The FSA will be in charge of appointing the scheme's Board, for writing its operating rules, and for annually reviewing its operations. ${ }^{30}$ Day-to-day handling of claims will be the responsibility of the scheme itself, however, which will be set up as a separate company. Like the schemes it replaces, the new compensation scheme will be funded by fees paid by authorized firms and by recoveries from firms in default. These fees will be determined based on "pay as you go" principles and the scheme will be free of cost for investors. The scheme will pay valid claims in full up to a fixed amount, completely phasing out payments above another higher amount. ${ }^{31}$

65. Altogether, this is a formidable range of regulatory and supervisory tasksencompassing activities responsible for about seven percent of the U.K. 's economy, employing over one million people, and providing essential services to virtually every U.K. citizen. Hence, it is unsurprising that this concentration of power into the hands of a single institution has raised concern in the U.K. public debate. The effort made by the U.K. government to allay these concerns by implementing a set of checks on the FSA's activities is discussed below, along with a number of other issues brought into the public policy focus by the ongoing regulatory reform.

\section{Establishing a Single Regulator of U.K. Financial Markets}

66. Without doubt, the aspect of the ongoing U.K. regulatory reform that has attracted the most widespread interest is the integration of financial supervision into the hands of a single regulator. Observers have focused on the prudential grounds for unifying the regulatory framework of disparate economic activities such as traditional retail banking, insurance, and securities investment; have questioned the political viability of attributing an enormous regulatory and supervisory power to a single institution; and have laid stress on the difficulty

\footnotetext{
${ }^{30}$ Thus, the FSA will also be responsible, subject to the provisions of EU legislation, for deciding on details of compensation and, in particular, on the extent that such compensation should differ across different financial sectors. Currently, the FSA envisions endowing the scheme with a single executive board and a set of harmonized administrative arrangements, but plans to articulate the scheme into three sub-schemes, each dealing with one of the three sectors of deposit-taking, insurance, and investment.
}

${ }^{31}$ For instance, the Investors Compensation Scheme, one of the investor protection measures established by the Financial Services Act 1986, currently pays the first $£ 30,000$ of a valid claim in full and 90 percent of the next $£ 20,000$. The other four main compensation schemes in the area of financial services are the Deposit Protection Scheme (protecting bank deposits), the Policyholders Protection Scheme (protecting against failures of insurance companies), the Building Societies Investor Protection Scheme and the Friendly Societies Protection Scheme (protecting against failures of Building Societies and Friendly Societies, respectively). 
posed by the separation of the lender-of-last-resort (LOLR) and the banking supervision mandates, following the attribution of the latter to the FSA.

67. There are, of course, grounds for arguing in favor of consolidated prudential supervision of multi-functional financial groups. To the extent that a single holding company manages the risks it takes over different financial activities (say, traditional retail banking and securities-trading) in a centralized fashion; and to the extent that risks taken across different lines of business are not perfectly correlated, then more efficient capital requirements can be set by taking into account correlations among risks with respect to the traditional buildingblock methodology. ${ }^{32}$

68. Efficiency gains in managing global (or "complex," to use the words of the FSA) groups, are an important goal of the U.K. reform and are further discussed below. However, a discussion of the tradeoffs faced by the U.K. government when it re-designed the domestic regulatory landscape must start from the recognition of the singular need for transparency and accountability that the U.K. government faced after a series of incidents in financial markets since the early-1990s had wounded the political viability of the previous regime. The list includes the 1990 fraudulent failure of Asil Nadir's Polly Peck, a stock-market star of the 1980s; accusations to the BoE of slowness in spotting the frauds which led to the July 1991 closing of the Bank of Credit and Commerce International; the collapse of the Maxwell empire; ${ }^{33}$ and the still not fully resolved incident of mis-selling of pension plans by a range of advisers in the 1980s - an event which the government itself has referred to as "one of the

${ }^{32}$ In Federal Reserve Chairman Greenspan's words, "risk managed on a consolidated basis cannot be reviewed on an individual legal entity basis by different supervisors." (Greenspan, 1997.)

${ }^{33}$ The collapse of the Maxwell empire in 1992, and the subsequent uncovering of a series of questionable financial practices in the management of the company's pension funds, is widely regarded as exemplary of the shortcomings of the existing regime of financial self-regulation. Between 1988 and 1990, Maxwell increased the proportion of pensions under the control of its main pension fund group, Bishopsgate Investment Management Ltd., from $28 \%$ to $75 \%$, calling in funds from outside firms that had managed them before. Maxwell then offered these funds as collateral against loans from British and international banks, and funneled funds to some of his ailing companies. When these firms collapsed after the media mogul's death in November 1991, little of the $\mathbf{f 4 0 0}$ million that investigators reported as plundered from the pension funds were left to recover. In the event, the chairman of MMO resigned in June 1992, following resignation of two other IMRO officials. IMRO had failed, on the evidence of its own internal inquiry, in its duty to monitor the Maxwell companies that managed most of the empire's pension funds, leading to widespread questioning of the ability of the organization to effectively police firms whose financial support was necessary for its own survival, and from which two-thirds of its directors were drawn from. (One of these directors was also a director of two Maxwell companies.) 
worst scandals in financial services this century," and whose cost in terms of consumer redress is currently estimated at about $£ 11$ billion. Beyond issues of efficiency intrinsic to a more integrated regulatory framework, it is clear that the driving force behind the move to a single regulator of U.K. financial markets, was the new U.K. Government's desire to establish a system that would be publicly accountable and transparent in its supervisory practices. ${ }^{34}$

69. In addition to its lack of transparency and inadequate accountability, the existing fragmented regulatory environment was also perceived as imposing unnecessary costs on the U.K.'s financial sector. Market participants viewed authorization and enforcement as ambiguous; supervisory responsibilities of the various supervisory bodies as overlapping and-in areas of overlap-as often working at cross purposes; information exchange between the various bodies as seriously deficient, when not outright non-existent, and causing significant increase in the data-reporting burden of authorized firms. ${ }^{35}$ These problems are exemplified by the existing authorization process: under the current arrangement, firms must seek authorization under more than one statute, in some cases from as many as five or six separate regulators, each operating under a different set of powers. ${ }^{36}$ Consumers of financial services have also found it difficult to determine the appropriate forum in which to file a complaint, resolve a dispute, and obtain compensation, facing no less than eight disputeresolution schemes and five compensation schemes covering the financial services area.

\footnotetext{
${ }^{34}$ A task which U.K. regulators have tackled independently from the current reform is that of strengthening certain supervisory practices which, by international standards, seemed somewhat light- especially as regards the depth of on-site visits and the collection and measurement of data on financial institutions' liquidity. Thus, for instance, U.K. regulators have responded in earnest to Arthur Andersen's 1995 review of U.K. banking supervisory practices and have implemented most of the reviewers' recommendations. A new risk-based supervisory framework for supervision of U.K. and non-EEA-incorporated banks (the RATE approach) is also being rolled out. The RATE approach involves a first-stage assessment of the risk profile of a bank - reflecting the nature of its business, the adequacy of its internal controls and its exposure to external risk factors - and the subsequent adjustment of the intensity of supervision, the frequency and depth of on-site visits, etc., to the perceived riskiness of each institution.
}

${ }^{35}$ See, for instance, Peacock and Bannock (1995). Illustrative of the extent of overlap is the FSA's self-imposed goal of reducing the body of legislation concerning financial regulation by 25 percent in its first year of operation and by 5 percent in each subsequent year.

${ }^{36}$ By contrast, in the new regime the FSA will not need to start an authorization process anew, when seeking to authorize a firm to expand its existing business; rather, it will rely on its own knowledge of the firm and merely extend an existing authorization to include new activities. 
70. Against this background, foremost in the government regulatory agenda was the desire to implement a structure whose political viability would be rooted in its transparency, clear attribution of responsibilities, accountability of decision-making, and-as much as appropriate-simplicity and homogeneity of regulation. In the event, maximum clarity of supervisory responsibility was sought by attributing all such responsibilities to a single body. Upon approval of the supporting legislation, this choice is to be counterbalanced by a number of elements, including: 1 . formal mechanisms to secure the Authority's public accountability; 2. information-sharing arrangements to strengthen the BoE's role in support of the country's financial system, including its monetary function and its responsibility for maintenance and improvement of the payments system; and 3. flexibility in prudential regulation, to assure that unification of supervisory responsibilities would not translate into a "one size fits all" approach to financial supervision. These items are discussed in the next sections.

\section{Consumer Protection}

71. In light of the perceived failure of the previous self-regulating system to protect consumers from abuses of financial services providers, the draft legislation assigns at least two of the FSA's main institutional goals squarely to the area of consumer protection and education. One of these is to "secure the appropriate degree of protection for consumers," while the other is to "promote public understanding of the financial system" (FSA, 1998e, p.6). Yet, while consumer protection is a major mandate of the FSA, the government has stated clearly that the FSA should not provide to consumers full insurance against authorized firms' failure to deliver as contracted. Rather, the FSA's goal is to promote "awareness of the benefits and risks associated with different kinds of investment or other financial dealing" while safeguarding "the general principle that consumers should take responsibility for their decisions" (Financial Services and Markets Bill, Clauses 4(2)(a) and 5(2)(c)).

72. In practice, the FSA plans to protect consumers of financial services by intervening at several stages: 1) by vetting firms at entry, to ensure that only those found to be "fit and proper" are permitted to conduct financial business; 2) by setting and enforcing prudential standards; 3) by using its powers of investigation, enforcement, and restitution against firms that fail to meet expected standards; 4) by setting a 'one-stop' arrangement for resolving disputes between consumers and authorized firms-the single "Financial Services Ombudsman Scheme"; 5) by overseeing the compensation of investors when an authorized firm is unable to meet its liabilities.

73. Unsurprisingly, the approach taken by the FSA to balance consumer protection with the preservation of strong elements of caveat emptor - consumers must take significant responsibility for their own financial decisions - has spurred a lively debate in the U.K.. Consumer interest groups have advocated the need for tighter regulation aimed at narrowing the scope for caveat emptor motives; financial services firms, at the other end, have advocated limiting the FSA's power of prosecution and pointed to the cost of consumer protection for the competitiveness of the U.K. 's financial services industry. 
74. The FSA's powers are indeed wide-even if, in many cases, the FSA will consider it sufficient to make a public statement of misconduct (see Clause 135 of the draft Bill). The FSA will be able to intervene in the business of authorized firms to correct non-compliance, to try to contain financial loss (or risk thereof) for consumers and to investigate the circumstances leading to these; it will be able to seek restitution and to discipline instances of misconduct by bringing criminal proceedings for certain offences (essentially, insider dealing and misleading statements and practices), imposing civil fines for market abuse, and withdrawing authorization to conduct business.

75. Are these powers too extensive? International practice, as well as the overriding need to secure political viability of the reformed regime, suggest that this may not be the case. On the first count, for instance, U.S. financial supervisors enjoy comparable powers, being able to investigate and seek penalties for both firms and individuals, impose fines, and withdraw authorization to conduct business. In fact, the BoE's lack of power to seek pecuniary penalties against banks had placed the U.K. among a minority of industrial countries subject to similar limitations. ${ }^{37}$ The need to secure political support of the reformed regime, in light of the widely recognized shortcomings of the previous regime, also required a quantum leap in the attribution of powers to the post-reform regulators. More fundamentally, attribution of strong powers to impose penalties ex post, may be an efficient and cost-effective way for regulators to prevent frauds and market abuse, given the difficulty of implementing effective ex ante systems and controls. ${ }^{38}$ The proposed legislation may have to be refined, to assure that it fits the standard of the European Convention on Human Rights and to further allay public concern with the Authority's use of power. ${ }^{39}$ However, it will be impossible for the FSA to specify in advance the exact contingencies under which it will exercise its investigative and

${ }^{37}$ Instefjord, Jackson, and Perraudin (1998), for instance, survey banking regulations in 17 industrial countries, and find only banking regulators in the U.K., Liechtenstein, the Netherlands and - to some extent - Japan, to be unable to fine banks for rule violations. By contrast, in their supervision of securities the U.K's SROs have traditionally enjoyed powers to fine both firms and individuals.

${ }^{38}$ As discussed by Instefjord, Jackson, and Perraudin (1998), for instance, establishing industry standards for internal systems and controls necessarily finds a limit in the need for such arrangements to be tailored to a firm's specific activities and organization. Furthermore, fax control environments rarely exhibit absence of key control systems; rather, they typically feature a practice of overriding or setting aside such controls- a practice which is very hard to check ex ante.

${ }^{39}$ One of thorniest issues to be resolved in the Bill concerns the use of evidence obtained under compulsion in civil cases that could carry unlimited fines, which some legal experts have argued might breach the European Convention. In FSA (1998g), the FSA has committed not to use such evidence in criminal cases under normal circumstances, a commitment that some public observers have asked to include as part of the final legislation. 
punitive powers. Operationally, the most reasonable and feasible goal is to ensure acceptable windows of appeal against FSA decisions, proper procedures for independent re-trial, and overall accountability of the FSA towards the political body. The proposed framework, which establishes several mechanisms to mitigate concern with possible excessive use of force by the FSA, places these goals well within reach.

76. First, the FSA's Board will continue to be appointed by the Chancellor of the Exchequer. Board members' term of appointment-usually lasting three years-is also rather short by the common standards of public institutions, and can be terminated by the Chancellor, who thus retains effective control of the Authority's governing body. The FSA's Board will have to report annually to the Chancellor on the fulfilment of its statutory objectives, with the Board's ten non-executive members charged with special reporting duties on the FSA's internal mechanisms and use of resources. The FSA will also be required to consult publicly on its proposed rule changes; to perform cost-benefit analyses of proposed regulatory requirements and fee changes; and to subject rule changes to competition vetting by the Director General of Fair Trading. Firms or individuals being investigated by the FSA will be able to refer their cases, make oral representations, and see FSA evidence in front of an Enforcement Committee, established by the FSA Board, with members chosen from practitioners and public interest groups and chaired by an external full-time professional. The FSA's enforcement and punitive decisions will also be subject to tight scrutiny. Firms will be able to appeal FSA decisions to the new, single Appeal Tribunal, established in complete independence of the FSA, as part of the Court Service administered by the Lord Chancellor's Department. The tribunal will be formed by individuals drawn from a panel of legal and financial experts, appointed by the Lord Chancellor, and will have the power to substitute its own decisions for that of the FSA and to award costs against either the FSA or the appellants. ${ }^{40}$

77. Overall, these requirements point to a dramatic improvement in the transparency and accountability of the financial supervisory process in the U.K., especially in the area of security trading, where formal public scrutiny of self-regulating agencies was hitherto minimal. Market participants, who generally welcomed the progress implicit in the move to a single regulator, had initially reacted vehemently to the draft Bill's outline of the FSA's enforcement powers, but have viewed the safeguards outlined in the consultation paper (FSA, 1998e)-discussed above-much more positively.

\section{E. Coordination of Lender-of-Last-Resort and Supervisory Responsibilities}

78. One of the main innovations the regulatory reform has introduced into U.K. financial system is the separation of the functions of banking supervision (henceforth attributed to the

\footnotetext{
${ }^{40}$ The FSA has also chosen to go beyond legislated requirements by establishing a Consumer Panel and a Practioner Forum, which are expected to comment publicly on FSA rules and its supervisory practice.
} 
FSA) and provision of emergency liquidity (or LOLR, for which the BoE will continue to be responsible). This separation, which followed the Government's recent granting of operational autonomy over monetary policy to the Bank of England, has generated a debate involving traditional arguments in favor and against lifting banking supervision responsibilities from the hands of an independent central bank.

79. Traditionally, advocates of a narrow role for central banks argue that if the central bank (or whichever institution performs the role of the LOLR) must provide liquidity assistance to avert a financial crisis, then it should do so only by providing liquidity to the market at large, e.g., through open market operations, leaving to the market the task of allocating liquidity to worthy borrowers. ${ }^{41}$ This conduct would minimize moral hazard, both for potential beneficiaries of liquidity rescues (which would have fewer incentives to assume socially excessive risks) and for other banks (who would need to step up peer monitoring and the associated market discipline). Expanding the role of a central bank to include supervisory responsibilities may also significantly raise the cost of a supervisory failure, which would damage the central bank's reputation and the credibility of its monetary policy. ${ }^{42}$

Furthermore, the mandates of banking supervision and of price stability are subject to a potential conflict of interest: a central bank responsible for supervision could lean towards lax monetary policy if this was perceived to avert bank failures. Reflecting these viewpoints, countries such as Germany, Japan, and - recently - Australia, have established rather separate functions of banking supervision and of LOLR. ${ }^{43}$

${ }^{41}$ See, for instance, Goodfriend and King (1988), Humphrey (1989), Schwartz $(1988,1992)$, Bordo (1990), and Kaufman (1991). See also Beaufort Wijnholds and Hoogduin (1995) for a general discussion.

${ }^{42}$ For instance, Goodhart and Schoenmaker (1993) have argued that the credibility of the Bank of England remained significantly impaired after the BCCI crisis.

${ }^{43}$ Germany is often cited as the classic example of separation of the roles of banking supervision and LOLR, the former being assigned to the Federal Banking Supervisory Office and the latter to the Liquidity Consortium Bank (Liquiditäts-Konsortialbank GmbH). In practice, however, the Bundesbank is involved in both functions, through its majority shareholding ( 30 percent) in the Liquidity Consortium Bank; through its holding of one of four seats in its Credit Committee; and by virtue of the fact that the Bundesbank effectively performs many functions of the Supervisory Office, which has no branches of its own and uses the Bank as an agent to collect supervisory data. The Bank also provides direct liquidity assistance when the LCB's liquid resources are insufficient. To a large extent, the ECB's setup is even more extreme than that of Germany. To date, the ECB has received no LOLR mandate (with no corresponding role being explicitly assigned to national agencies), no explicit mandate for crisis management, nor for banking supervision (which remains the responsibility of national authorities) and only limited access to supervisory information 
80. By contrast, countries such as the U.S., Italy, and (to some extent) France have opted for a broad central bank role, combining both monetary policy/LOLR and banking supervision responsibilities. ${ }^{44}$ One argument in support of this approach emphasizes that a central bank charged with supervisory responsibilities gains information on the banking system which improves its ability to conduct monetary policy, by allowing it to better assess the transmission of monetary policy to prices. ${ }^{45}$ This perspective is particularly useful, it is argued, in times of financial distress, given the failure of private markets to allocate liquidity efficiently among banks. In the absence of central bank intervention, such market failure would lead to excessive liquidation of banks and to financial instability. ${ }^{46,47}$

\section{${ }^{43}$ (...continued)}

(which will be released at the discretion of national supervisory authorities, on a case-by-case basis). See Prati and Schinasi (1998) for a detailed analysis.

${ }^{44}$ Overall, industrial countries are fairly evenly split with respect to the practice of combining or separating supervisory and monetary functions (see Table 1). About half of them have kept both functions within the central bank, while the other half have typically assigned banking supervision to an agency controlled by the ministry of finance. (Among others, France uses an hybrid system whereby a relatively independent Commission Bancaire supervises compliance with regulations, although inspections are delegated to the Banque de France.)

${ }^{45}$ See, for instance, Goodhart (1987), Flannery (1996), Goodhart and Huang (1998), and Bini Smaghi (1998a).

46 The traditional approach to LOLR activities, developed by Bagehot in the XIX century, calls for letting insolvent banks fail and lending only to solvent but illiquid banks, and for lending speedily, for the short term, at penalty rates, and against good collateral. This approach is still broadly endorsed by the regulatory community, with two main caveats: support may have to be denied to banks that - even if solvent - are found responsible for their liquidity problems; and support may have to be granted to banks - even if insolventwhose failure would have systemic repercussions. The first caveat (see Rochet and Tirole, 1996, for discussion and a model) reflects the need to deter moral hazard on the part of banks, who may have otherwise an incentive to assume excessive risk. The second caveat rests on informational gaps preventing achievement of the first-best solution, which would be to let insolvent banks and their insolvent creditors fail, and to assist only their solvent- but now illiquid - creditors. This gap arises because even a LOLR/ supervisor may lack the information needed to implement a selective rescue. Hence, it may prefer to rescue an insolvent bank to letting its failure snowball on to its potentially viable creditors.

${ }^{47}$ Evidence on the relative performance of systems with joint and separate LOLR and supervisory responsibilities is weakly supportive of a tendency toward laxer monetary policy 
81. Supporters of the link between the LOLR and supervisory mandates also argue that this link provides scope for the very existence of the LOLR mandate. This is because a LOLR can provide liquidity assistance more efficiently than the market only if it holds an informational advantage on the financial condition of financial institutions over the market itself. For instance, a LOLR endowed with intimate knowledge of a bank's assets, liabilities, and overall position in the payment system, would be able to determine that a bank unable to borrow from the private market (because believed to be insolvent) was, in fact, merely illiquid. The LOLR can also use its privileged information to determine the quality of the bank's collateral and the appropriate penalty to be charged on the rescue loan-commensurate with the bank's responsibility for its own financial ills. If, instead, the LOLR determines that the bank is a candidate for closure, it can use its information on the bank's financial structure, lenders, and clients, to assess the systemic implications of the bank's wind-up.

82. How does a LOLR gain this informational advantage? By accessing bank-specific information collected in the course of its supervisory activity. This information must often be used within a very short time - sometimes within a few hours or minutes, as in the Bank of New York incident of 1985 , when a computer failure threatened a payment system crisis and required prompt liquidity assistance by the Federal Reserve. And, armed with this information, a central bank could "use techniques that are less blunt [than flooding the market with liquidity through open market operations] and more precisely calibrated to the problem at hand. Such tools improve [the bank's] ability to manage crises and, more importantly, avoid them." (Greenspan, 1997). If the LOLR has no informational advantage, then it can efficiently lend funds only to institutions that could also borrow funds efficiently in the free market.

\section{${ }^{47}$ (...continued)}

by central banks also charged with supervisory responsibilities. Many observers (see, for instance, Goodhart and Schoenmaker, 1995) view the Fed as having maintained a more relaxed monetary stance in the late 1980s than it would have been required by purely monetary considerations, in response to U.S. banks' difficulties during that period. Goodhart and Schoenmaker (1993) have also suggested that the Bank of England's reluctance to increase interest rates to defend sterling's ERM parity in 1992 partly reflected its fears of creating problems for some domestic banks, although $\mathrm{BoE}$ officials have denied this view. More systematic evidence includes work by Heller (1991), Goodhart and Schoenmaker (1993), and Bini Smaghi (1998b), who find higher inflation in countries where central banks are assigned supervisory responsibilities along with their traditional monetary policy mandate. In general, the reduced-form nature of these studies calls for caution, due to possible smallsample, simultaneity, and omitted-variable problems. For instance, Bini-Smaghi notes that a tight exchange rate policy may account for the favorable inflation performance of countries such as the Netherlands, more so than these countries' choice of separate LOLR and supervisory functions. 
83. In any case, even if one subscribes to the need of maintaining a close informational link between the LOLR and the supervisory authorities, it does not follow that the same institution should play both roles. Rather, the implication is that - in case of separation- the two institutions should cooperate closely with each other, and that the LOLR should have swift and unrestricted access to supervisory information. In the case at hand, the issue is whetherin the event of a financial crisis - the BoE would have smooth and unrestricted access to the supervisory information collected by the FSA, and whether it would have the expertise to analyze it quickly, given the reassignment of most of its supervisory staff to the FSA in recent months.

84. Provision for effective information exchange between the Treasury, the FSA, and the BoE are made in a Memorandum of Understanding (see Appendix A) signed by the three institutions in October 1997. Not only does the Memorandum require the FSA to provide to the Bank "free and open access" to supervisory records; ${ }^{48}$ it also establishes a number of channels to secure continued dialogue between the two institutions. These include crosssitting of top management of the two institutions in their counter-party's governing body, monthly meetings of a "Standing Committee" of the institutions' top managers, ${ }^{49}$ and programs of reciprocal staff secondment. Additionally, informal exchange will be aided, in the near future, by the recent transfer of many BoE supervisory staff to the FSA. Responsibilities for crisis management are also well defined, assigning to the BoE formal and technical responsibility for decision and implementation, subject to consultation with the Treasury and the FSA, and subject to the Treasury's veto power on the decision to proceed with a rescue. Beyond formal assignment of responsibilities, in practice one expects a rather collegial handling of crises among the three agencies, reflecting the key nature of the information held by the FSA, and the Treasury's overall responsibilities for supporting legislation, provision of fiscal resources, as well as its ultimate accountability to Parliament.

85. There are questions, of course, regarding the ability of crucial informal channels to continue to operate effectively once the inherited familiarity between BoE and FSA staff evaporates. There is also a tension between the basic argument underlying the U.K. regulatory reform - that merging supervisory responsibilities of nine separate bodies would foster regulatory synergies and smooth information flows-, and the argument that splitting LOLR and banking supervision responsibilities would not have an effect to the contrary. However, one should consider that even before supervisory responsibilities were transferred to the FSA, managing information within the Bank had become a major task, given the

\footnotetext{
${ }^{48}$ Thus, for instance, the FSA's regular analysis of the U.K. banking system is copied to the BoE.
}

49 While formal membership of the Standing Committee consists of the Chancellor of the Exchequer, the Governor of the Bank of England, and the FSA's Chairman, the committee meets routinely at the three institutions' deputy level. Meetings last typically one-to-two hours, and minutes of the meeting are circulated to the institutions' top managers. 
extraordinary growth of its banking supervision staff over the years. Furthermore, even in the pre-reform regime, the Bank was not acting in isolation from other regulatory bodies when crucial LOLR decisions had to be made- as the cooperation between the Bank and the SFA in handling the Barings episode demonstrates.

86. In most circumstances, the BoE, the FSA, and the Treasury would certainly have at their disposal the time necessary to coordinate on proper crisis management and resolution-as well as the appropriate accountability in place to secure the three institutions' contribution to the task. Insight on the circumstances in which need for LOLR intervention would practically arise may be gathered by observation of the BoE's record in this respect. Historically, the Bank has been very reluctant to undertake LOLR operations, following its stated policy of intervening only in support of banks whose failure could have systemic effects. In recent years, rescue operations were mounted only in 1984, in the case of Johnson Matthey Bankers Ltd., and in 1991, when the Bank intervened in response to pressure on the interbank market, resulting from a number of domestic clearing and foreign banks'-as well as local authorities' - withdrawal of funds from smaller banks and building societies. ${ }^{50}$ By contrast, the BoE did not intervene in support of BCCI in 1991 and of Barings in 1995, viewing these banks' closure as void of systemic implications. Thus, a scenario where the separation of LOLR and banking supervision responsibilities might challenge the BoE's expertise and indirect access to supervisory information would have to feature a fast-breaking crisis, requiring immediate liquidity assistance, and having uncertain systemic implications. Emphasis on systemic risk as pre-condition for LOLR support, the Bank's continued responsibility for support of the nation's financial system, and its independent access to information from the domestic and international financial markets and payments systems, however, suggest that the Bank would continue to hold expertise in most cases when called upon intervening without much time to consult with the FSA-as in a Bank-of-New-York style payments failure, for instance. But the BoE and the FSA must stand ready to implement the necessary changes in their information-sharing arrangements to assure their effective cooperation during crisis events whose non-'technical' nature require complex and rapid

\footnotetext{
${ }^{50}$ In 1984, the BoE rescued Johnson Matthey Bankers Ltd. (JMB) because of its stated concern that failure could trigger problems elsewhere, especially in the interbank gold market. Unable to find a buyer for JMB, the Bank purchased JMB itself for 11 , after persuading the parent company to inject $£ 50$ million. The BoE provided an indemnity of $£ 150$ million, and arranged for a counter-indemnity from other participants in the gold market of 50 percent of any loss. Eventually, the losses were largely recouped, and very little public money was lost - although this turn of events may have not been expected from the outset. In 1991, the BoE provided indirect liquidity in the form of guarantees to the clearing banks (which only then accepted to fund the troubled banks) and later made provisions for $£ 95$ million to cover the resulting losses, when some of the guaranteed banks became insolvent.
} 
decisions. ${ }^{51}$ In recent months-including the eventful Fall 1998 period-existing arrangements have been reported as effective in securing information exchange and cooperation between the two institutions. Preventing the two institutions from drifting apart as they settle into their separate mandates and the inherited familiarity between the two institutions' staff vanishes, will be key to the continued success of this experience.

\section{F. "Constructive" Ambiguity?}

87. A widely held view among advocates of an active LOLR mandate is that central banks (or whoever performs the function of LOLR) may deter banks' tendency to assume excessive risk by keeping details of LOLR practices "constructively" ambiguous, i.e., by retaining discretion as to whether, when, and at what conditions, emergency liquidity support will be provided. ${ }^{\text {s2 }}$

88. One basis for this view rests on the presumption that risk-averse banks will respond to greater uncertainty, both on the terms of a bail-out and on whether liquidity assistance will be provided or not, by reducing their engagement in risky activities (see, for instance, Corrigan, 1990). Another argument emphasizes that a LOLR should retain discretion on the exact terms of a rescue (including relevant penalties) so as to be able to tailor them to the specific contingencies of the bail-out: higher penalties (possibly, a wind-up) should be imposed for banks that are found to be responsible for their own financial ills- so as to penalize moral hazard in their choice of portfolios; vice versa for banks who fall victims to external circumstances.

89. Countering the benefit of reduced moral hazard, ambiguity undermines supervisors' accountability, by making their responsibilities less clearly defined. It also induces a bias towards forbearance: a supervisor may allow a troubled bank to continue to operate with the hope of its eventual recovery, especially if it was a supervisory failure that prevented early detection of the problem. Finally, it may increase the scope for inefficient bail-out policies: lacking pre-commitment to a detailed rescue policy, a LOLR may be more lenient with banks

\footnotetext{
${ }^{51}$ For instance, some observers have suggested the potential usefulness of programs of reciprocal briefings by the two institutions on their respective activities, as well as a formal representation of the FSA at meetings of the Bank's Monetary Policy Committee- paralleling a similar arrangement for the Treasury.

${ }^{52}$ Of course, ambiguity in LOLR arrangements may simply reflect a LOLR's inability to know in advance the exact contingencies in which its support will be required, including the difficulty of defining ex ante systemically relevant financial institutions. However, the usual argument is that much ambiguity in LOLR policies is intentional, and goes beyond the technical difficulty of writing a 'complete' contract with financial institutions as to the terms of a potential rescue.
} 
ex post than threatening ex ante; recognizing this incentive, banks will respond by assuming an excessive amount of risk in their portfolios.

90. Accordingly, regulators must walk a fine line when designing LOLR mechanisms. Traditionally, the trade-off between rules and discretion in the design of LOLR procedures has been tackled by maintaining ambiguity on the exact terms of a liquidity rescue, but by clarifying decision-making responsibilities and the decision-making process. From this viewpoint, the U.K. model for crisis-management falls squarely in this category: while the division of responsibility between BoE, FSA, and Treasury in the event of a crisis is well specified, the exact terms of the emergency response are not. Paragraph 12 of the Memorandum, in particular, stipulates that "The form of the response would depend on the nature of the event and would be determined at the time". Paragraph 13 even maintains ambiguity on whether liquidity assistance would actually be provided or not: "the Bank and the FSA [...] would immediately inform the Treasury, in order to give the Chancellor of the Exchequer the option of refusing support action." The Bank of England - similar to the U.S. Federal Reserve, and unlike the Bundesbank - also enjoys considerable discretion in deciding what type of collateral may be acceptable in exchange for emergency liquidity provision.

91. Thus, the extent of ambiguity in the U.K. 's approach to emergency liquidity operations is fairly standard and intentional. In this context, however, prompt sharing of information by the FSA with Treasury and the Bank; transparent (at least ex post) account of decisions to rescue or close a financial institution; and adequate sharing of costs of failures among managers, share-holders, and creditors, will be essential in securing the economic and political viability of the system. The appropriate legislative ingredients are being assembled. Only experience will tell whether the new regulatory regime will resolve the subtle tradeoff between discretion and transparency - in essence, whether the ambiguity introduced into the mix is "constructive"or just plain "ambiguous."

\section{G. Regulatory Reform and Financial Innovation}

92. Like most financial regulatory systems of the leading industrial countries, the U.K.'s pre-reform framework largely reflected the product segmentation prevailing in financial markets until the 1980 s, involving a marked separation between banking, securities, and insurance activities and the resulting assumption that banks would incur risks mainly in connection with their lending activities - the "credit" risk that a borrower would fail to meet its loan obligations. This structure justified separate regulatory agencies and prudential requirements for each activity, resulting in the absence of a single regulator in charge for examining the whole of a complex group's activities. The perception that credit risk could usually be identified in advance - and was relatively stable at high frequency - also underlay the rather infrequent (usually quarterly) collection of information and limited disclosure.

93. The major expression of this regulatory approach was the Basle Capital Accord of 1988, as reflected in the EC's Solvency Ratio Directive, implemented in the U.K. in December 1990. This system hinges on requirements that a financial institution should maintain minimal 
ratios between its capital and its risk-weighted assets, the latter computed based on a buildingblock methodology weighting various assets by their individual riskiness. Following the deregulatory initiatives of the 1980s, the blurring of the demarcation between traditional banking and other financial activities and the growing exposure of banks and other financial institutions to fluctuations in the prices of their securitized assets clearly showed the traditional system of regulation to be inadequate. Regulators increasingly recognized that 'market risk' had to be taken into account when assessing a financial institution's exposure to shocks. Moreover, they also had to grapple with the growing ability of financial operators to un-bundle, repackage, and trade risks in increasingly creative ways, so much so that the regulators' task of assessing the distribution of private financial risk across institutions, markets, and countries, was becoming increasingly arduous. This was especially so if regulators were working in a fragmented fashion, and were constrained to focus on a single aspect of an institution involved in a broad array of financial activities and in the trade of a variety of hybrid financial assets.

94. Recent EU directives in the area of financial regulation have enhanced the ability of EU regulators to cope with financial innovation. The Capital Adequacy Directive (CAD), implemented in the U.K. in January 1996, extends the prudential framework to consideration of market risk, and provided some scope for regulators to recognize internal models for risk assessment. CAD II, implemented in the U.K. at end-September 1998, builds on the 1997 Amendment to the Basle Accord and further expands the scope for financial institutions to use internal risk-assessment models, covering potentially all of an institution's risks. ${ }^{53}$

95. Through the ongoing regulatory reform and the associated move to a single financial markets regulator, U.K. regulators are also seeking to overcome the difficulty of assessing and managing risk in complex financial institutions. Within the new regulatory framework, groups of authorized firms or firms with more than one authorization will be subject to lead supervision within the FSA that will identify a single supervisor responsible for coordinating the FSA's supervision of the group or firm, including the assessment of the overall risk exposure of the group. The FSA has identified about 55 institutions whose multi-functionality qualifies them for such treatment, and plans to begin by experimenting with unified supervision of a limited number of such groups.

96. Integrated supervision does not mean that U.K. regulators will seek to homogenize prudential requirements across different lines of business. In fact, flexibility in prudential requirements is entrenched in U.K. regulation: capital requirements differ not only across financial sectors, but among firms in the same sector, in recognition of the specificity of risks associated with each institution. However, the ongoing reform is aimed at providing a level

\footnotetext{
${ }^{53}$ For the moment, however, the use of such models for regulatory capital purposes is limited to management of market risk. Although a number of market participant have asked to use VaR models also to determine regulatory capital against credit risk, regulators in the U.K. and elsewhere have so far resisted this attempt, and changes in this direction are not incipient.
} 
playing field across financial sectors with respect to authorization procedures, standards for consumer protection, enforcement process, and appeal procedures. Emblematic will be the FSA's approach to consumer protection, where the Authority's main goal is to establish criteria for "fitness for purpose" applicable across financial sectors and a common prosecution procedure for all authorized firms.

97. Through the establishment of an agency with a unified view on complex groups' activities, U.K. regulators also hope to make inroads towards monitoring and controlling the vulnerability of U.K. financial markets to international risk factors: multi-functional conglomerates, after all, tend to be the same groups that take positions on an international scale, and provide the crucial link - particularly in times of crises- among payment systems of different countries. However, in their effort to control the role of complex groups in transmitting risk internationally, U.K. regulators face an internationally common plight.

98. Contrasting with the increasingly international integration in the provision of financial services, the supervision of financial markets has remained a national preserve, despite considerable progress made in harmonizing national regulations. Home-based supervision of activities with significant cross-border spill-over effects implies- in typical public finance fashion - shortcomings in the efficient provision of supervisory effort. First, no single national regulator has an overall picture of an international conglomerate's activity, thus exacerbating information asymmetries and the resulting incentives for international conglomerates to assume excessive risk. Second, no single supervisor reaps the full benefit of its effort to avoid a global financial crisis, thus typically leading supervisors to expend lessthan-optimal crisis-prevention effort. Third, should a crisis indeed occur, no single national regulator or LOLR could adequately assess its overall implications, nor feel sufficiently responsible for bearing the cost of its resolution.

99. One answer that the regulatory community has given to this problem is to harmonize national regulations internationally, while leaving the implementation of supervisory effort decentralized. This strategy provides a partial answer to the need for international coordination, mitigating the scope for financial firms to arbitrage across regulatory regimes. ${ }^{54}$

\footnotetext{
${ }^{54}$ London has direct experience of financial institutions' tendency to locate in less-regulated environments. The development of euromarkets in the 1950s and 1960 s provides a classic example, with London benefitting from restrictive regulations in the U.S. Another example is the BoE's adoption in 1997 of a more flexible regulation of credit derivatives, which were allowed to be placed on banks' trading books. This initiative enhanced the appeal of the London credit derivatives market and is viewed by many as having helped the City compete with New York for these instruments' trading. (London now accounts for over half of worldwide credit derivative trading.) Conversely, the migration of business from SEAQ-I - the London Stock Exchange's system for continental European equities- towards continental exchanges before the recent partnership between the London Stock Exchange and the
} 
However, capital standards remain rather heterogeneous internationally, despite the auspices of the Basle Committee and the implementation of a number of relevant EU directives, for instance reflecting cross-country differences in the activities admitted as required capital. Supervisory practices also continue to vary significantly across countries (see Barth, Nolle, and Rice, 1997, and Prati and Schinasi, 1998, for a discussion). At least, memoranda of understanding, such as that agreed upon by the FSA and the BoE with the U.S. Security and Exchange Commission and Commodity Futures Trading Commission in 1997, attempt to establish procedures for supervisory cooperation and sharing of information. Nevertheless, some observers have seen these efforts as limited in their goal of clearly assigning responsibilities for crisis management and resolution, and the U.K. government and supervisors have advocated the establishment of more structured fora to tackle these issuesa sort of "Global Standing Committee"- , involving national regulators, the IMF, and other multilateral agencies.

100. While these efforts are ongoing, the U.K.'s regulatory reform will at least magnify its regulators' perspective on global issues, through their enhanced viewpoint on complex groups. Indeed, some BoE officials have noted that their ability to handle and resolve a financial crisis may have been strengthened by moving from a narrow (but direct) perspective on the banking sector, to a global (though partly indirect - through FSA intermediation) perspective on the U.K. financial sector as a whole.

101. The ongoing reform of financial regulation may also contribute to increase the appeal of the City's market with respect to its foreign counterparts. Pending further progress, for instance, EMU financial institutions will be operating under a fairly complex framework, whose management will be split among a multitude of institutions (ECB, national central banks, regulators and treasuries, etc.), without a clear LOLR mandate nor well-defined arrangement for crisis management and resolution (see Prati and Schinasi, 1998, for a discussion). Ceteris paribus, London's traditional appeal in terms of a well-developed legal framework, light regulatory burden, and supporting legal and accounting services will be enhanced by a more coherent and transparent supervisory framework. This is no small matter for a major world financial center which - unlike either New York or Tokyo- is not backed by a large domestic economy.

\section{H. Concluding Remarks}

102. Clearly, an issue that will be long debated will be whether the move to a single regulator is the most effective way to address the shortcomings of the pre-existing regime, or

\footnotetext{
${ }^{54}$ (...continued)

Deutsche Börse, has been ascribed in part to a wave of reform by the latter exchanges, which involved restructuring their auction systems by liberalizing membership, reducing transaction taxes, and introducing greater transparency and continuous, order-driven trading (see Pagano, 1996).
} 
whether a shared arrangement such as that prevailing in the U.S. and other countries would have better safeguarded against excessive homogenization of supervisory practices across heterogeneous financial activities and against the creation of an all-too-powerful regulatory body. On the whole, however, the ongoing U.K. reform has struck a good balance, by providing adequate flexibility for the supervisory arrangement to deal with the country's diverse financial environment, and by implementing a series of checks to make the single regulatory body accountable to Parliament and to the public at large. The government has clearly identified areas where establishing common procedures across financial activities is beneficial: a single authorization process, a single compensation scheme, a single ombudsman scheme, a single appeals tribunal, and new common powers to tackle market abuse. At the same time, it has also identified areas where differences among financial sectors have to be maintained - mainly with respect to prudential treatment.

103. There are areas where U.K. regulators are likely to encounter challenges. Some of these challenges reflect, to a large extent, the innovative nature of the newly established framework, such as the separation of supervisory and LOLR responsibilities. Other challenges pre-exist the reform, including strengthening supervisory practices along recently planned lines and the difficulty of supervising a large, internationally integrated financial market. In light of these challenges, and given the novel and comprehensive nature of the reform, legislative flexibility - the government's willingness to adapt the regulatory framework in response to emerging needs - will be the key to keeping up with an industry in continuous and rapid evolution. 
Table 1. Monetary and Supervisory Agencies

\begin{tabular}{|c|c|c|}
\hline Country & Monetary Agency & Supervisory Agency \\
\hline Australia & Reserve Bank of Australia (CB) & Australian Prudential Regulatory Authority \\
\hline Austria & National Bank of Austria (CB) & (Federal) Ministry of Finance (MF) \\
\hline Belgium & National Bank of Belgium (CB) & Bank and Finance Commission \\
\hline Canada & Bank of Canada (CB) & Office of the Superintendent of Financial Institutions (MF) \\
\hline Denmark & Danmarks Nationalbank (CB) & Financial Supervisory Agency (MEA) \\
\hline Finland & Bank of Finland (CB) & Financial Supervision Authority (CB) \\
\hline France & Banque de France (CB) & Banque de France (CB) Commission Bancaire \\
\hline Germany & Deutsche Bundesbank (CB) & Federal Banking Supervisory Office Deutsche Bundesbank (CB) \\
\hline Greece & Bank of Greece (CB) & Bank of Greece (CB) \\
\hline Hong Kong, China & Hong Kong Monetary Authority (CB) & Hong Kong Monetary Authority (CB) \\
\hline Ireland & Central Bank of Ireland (CB) & Central Bank of Ireland (CB) \\
\hline Italy & Banca d'Italia (CB) & Banca d'Italia (CB) \\
\hline Japan & Bank of Japan (CB) & Financial Supervisory Agency \\
\hline Netherlands & De Nederlandsche Bank (CB) & De Nederlandsche Bank (CB) \\
\hline New Zealand & Reserve Bank of New Zealand (CB) & Reserve Bank of New Zealand (CB) \\
\hline Norway & Norges Bank (CB) & Banking, Insurance and Securities Commission (MF) \\
\hline Portugal & Banco de Portugal (CB) & Banco de Portugal (CB) \\
\hline Spain & Banco de Espana (CB) & Banco de Espana (CB) \\
\hline Sweden & Sveriges Riksbank (CB) & Swedish Financial Supervisory Authority \\
\hline Switzerland & Swiss National Bank (CB) & Federal Banking Commission \\
\hline United Kingdom & Bank of England (CB) & Financial Services Authority \\
\hline \multirow[t]{4}{*}{ United States } & Federal Reserve Board (CB) & Office of the Comptroller of the Currency (MF) \\
\hline & & Federal Reserve Board (CB) \\
\hline & & State governments \\
\hline & & Federal Deposit Insurance Corporation \\
\hline Venezuela & Banco Central de Venezuela (CB) & Superintendency of Banks \\
\hline
\end{tabular}

Source: elaboration on Goodhart and Schoenmaker (1995).

Note: The sample covers the OECD countries, Hong Kong, China, and Venezuela.

$\mathrm{CB}=$ Central Bank, MEA = Ministry of Economic Affairs, $\mathrm{MF}=$ Ministry of Finance. 


\section{RELATIONSHIPS BETWEEN THE FSA, THE BANK OF ENGLAND, AND HM TREASURY}

The division of responsibilities in the area of financial stability among the FSA, the BoE, and HM Treasury, was clarified in a Memorandum of Understanding signed by the three institutions and released on October 10,1997. According to the Memorandum:

The BoE is responsible for the overall stability of the financial system, for acting daily in money markets to deal with fluctuations in liquidity and to assure the stability of the monetary system, for supporting and improving financial infrastructures (domestic and international payments systems) so as to help reduce systemic risk and promote the international competitiveness of the City, and for providing lender of last resort services. The Bank will also be responsible for developing a broad overview of the financial system as a whole and advise the Chancellor on inherent problems as well as on the impact of financial events on monetary conditions.

The Treasury is responsible for the overall institutional structure and legislation of regulation, although it has no operational responsibility for the activities of the FSA and the Bank. It is kept informed by the FSA and the Bank on possible problems which could disrupt the economy at large, require an operation of public support, involve diplomatic or foreign relations, require legislative change, or may lead to questions to Ministers in Parliament.

The FSA is responsible for authorizing and supervising banks, investment firms, insurance companies, friendly societies, clearing and settlement systems, and financial markets in general, and for acting in response to problems arising in these areas when these operations do not fall within the scope of the Bank of England-including changes in capital or other regulatory requirements and when capital must be introduced into a troubled firm by a third party. (In some cases, the FSA and the Bank may substitute for each other in providing these services, when action by both institutions would result in a duplication of responsibilities; in this case, service agreements between the two institutions will specify agreed standards, timing details, and possible charges.) The FSA is responsible for collecting the bulk of the information on the firms it supervises, working with the Bank to minimize duplications in data collection. Several information-sharing arrangements between the two institutions should assure smooth information exchange between the FSA and the Bank. These include: monthly meetings (also involving the Treasury) of the Standing Committee, whose goal is to discuss individual cases and general developments in the area of financial stability; sitting of the Bank's Deputy Governor for Financial Stability in the FSA's Board and of the FSA's Chairman on the Bank's Court; and programs of reciprocal staff secondment. 


\section{REFERENCES}

Barth, J. R., D. E. Nolle, and T. N. Rice (1997), "Commercial Banking Structure, Regulation and Performance: An International Comparison," Contemporary Banking Issues 23:11.

Bini Smaghi, L. (1998a), "Who Takes Care of Financial Stability in Europe?" Bank of Italy, manuscript (September).

Bini Smaghi, L. (1998b), "Does Prudential Supervision Interfere With Monetary Policy? Some New Evidence," Bank of Italy, manuscript.

Bordo, M. D. (1990), "The Lender of Last Resort: Alternative Views and Historical Experience," Federal Reserve Bank of Richmond, Economic Review, 18-29

Corrigan, G. E. (1990), Testimony Before the Senate Committee on Banking, Housing and Urban Affairs, May 3, in Bulletin of the Federal Reserve Bank of New York.

De Beaufort Wijnholds, J., and L. Hoogduin (1994), "Central Bank Autonomy: Policy Issues," in De Beaufort Wijnholds and Hoogduin (eds.), A Framework for Monetary Stability, 75-95.

Financial Services Authority (1998a), Financial Services and Markets Bill: A Consultation Document, London: Financial Services Authority, July.

Financial Services Authority (1998b), The open approach to regulation, London: Financial Services Authority, July.

Financial Services Authority (1998c), Meeting our responsibilities, London: Financial Services Authority, August.

Financial Services Authority (1998d), The FSA Principles for Businesses, London: Financial Services Authority, September.

Financial Services Authority (1998e), The Financial Services Authority, London: Financial Services Authority, September.

Financial Services Authority (1998f), Promoting public understanding of financial services: a strategy for consumer education, London: Financial Services Authority, November.

Financial Services Authority (1998g), Financial services regulation: Enforcing the new regime, London: Financial Services Authority, December. 
Flannery, M. J. (1996), "Financial Crises, Payment System Problems, and Discount Window Lending," Journal of Money, Credit, and Banking 28:4, 804-831.

George, E. (1993), "The Second Bank of England/LSE Lecture," speech given at the London School of Economics, on November 18, 1993.

George, E. (1994), "International Banking, Payment Systems, and Financial Crises," in Proceedings of International Symposium on Banking and Payment Services, Board of Governors of the Federal Reserve System, December.

Goodfriend, M., and R.G. King (1988), "Financial Deregulation, Monetary Policy, and Central Banking," Federal Reserve Bank of Richmond Economic Review May/June.

Goodhart, C. (1987), "Why Do We Need a Central Bank?" Oxford Economic Papers 39, 75 89.

Goodhart, C., and D. Schoenmaker (1993), "Institutional Separation Between Supervisory and Monetary Agencies," LSE Financial Markets Group, Special Paper No. 52.

Goodhart, C., and D. Schoenmaker (1995), "Should the Functions of Monetary Policy and Banking Supervision be Separated?" Oxford Economic Papers 47, 539-560

Goodhart, C., and H. Huang (1998), "A Model of the Lender of Last Resort," mimeo, LSE, September.

Greenspan, A. (1997), Testimony Before the Subcommittee on Capital Markets, Securities, and Government Sponsored Enterprises, March 17.

Heller, R. (1991), "Prudential Supervision and Monetary Policy," in J. Frenkel and M. Goldstein (eds.), International Financial Policy: Essays in Honor of J. Pollak, (Washington, DC: IMF).

Instefjord, N., Jackson, P., and W. Perraudin (1998), "Securities Fraud," Economic Policy, October, 58-623.

Jackson, P., and W. Perraudin (1998), "Testing value-at-risk approaches to capital adequacy," Bank of England Quarterly Bulletin, 38:3, August, 256:266.

Kane, E. J. (1992), "The Incentive Compatibility of Government-Sponsored Deposit Insurance Funds," in Barth, J.R. and R.D. Brumbaugh (eds.), The Reform of Federal Deposit Insurance: Disciplining the Government and Protecting Taxpayers, New York: Harper Collins, 144:166. 
Kaufman, G.C. (1991), "Lender of Last Resort: A Contemporary Perspective," Journal of Financial Services Research 5(2) 95:110.

Large, A. (1995), “The U.K. 's Experience of Financial Services Regulation," the Securities and Investment Board Press Office.

Pagano, M. (1996), “The Cost of Trading in European Equity Markets," LSE Financial Markets Group, Special Paper No. 83

Peacock, A., and G. Bannock (1995), The Rationale of Financial Services Regulation: Is the Current Structure Cost-Effective and Working? Graham Bannock and Partners Ltd., London.

Prati, A., and G. Schinasi (1998a), "Financial Stability in EMU," IMF, forthcoming in Princeton Studies in International Finance.

Rochet, J.-Charles, and J. Tirole (1996) "Interbank Lending and Systemic Risk," Journal of Money, Credit, and Banking 28:4, 733-762.

Schwartz, A. (1988), Financial Stability and the Federal Safety Net," in Haraf, W. S. and R. M. Kushmedier (eds.), Restructuring Banking and Financial Services in America, Washington DC: American Enterprise Institute for Public Policy Research.

Schwartz, A. (1992), "The Misuse of the Fed's Discount Window," Federal Reserve Bank of St. Louis Review, September/October, 58-69. 


\section{UNITED KINGDOM BUSINESS CYCLE AND EMU ENTRY ${ }^{55}$}

\section{A. Introduction}

104. The U.K. government has announced five economic tests that would need to be met before entry into EMU. These tests require sustainable convergence between the United Kingdom and the EMU countries so that a unified interest rate policy would make economic sense; sufficient flexibility in the United Kingdom to cope with economic change; and grounds to believe that EMU will have favorable effects on investment, the financial services industry, and employment.

105. Of these tests (criteria) the first has been accorded prominence by both the authorities and outside commentators: it appears to be less ambiguous than the rest and it is the only one that clearly depends on the relative cyclical position of the U.K. economy. The other tests, by contrast, are more structural in nature and unlikely to be influenced by policy in the short term. They also seem intrinsically vague, which would make it harder to decide if they are met. ${ }^{56}$ The significance of the convergence test is heightened by the contention that historically U.K. business cycles have been more volatile than, and not particularly synchronized with, those of the prospective EMU members (Figure 1) ${ }^{57}$ The implication is that cyclical convergence may not occur naturally by the time that the United Kingdom may seriously contemplate joining (2002 the earliest).

106. This Chapter examines the empirical properties of the U.K. business cycle, its relationship with those in major economies of Europe and North America, and its principal determinants. The objective is to evaluate the relevance of the convergence criterion and identify the factors (in particular policy variables) that will influence the likelihood of convergence.

107. The issue of whether cyclical convergence is a sensible criterion is not discussed in the Chapter. While, from a currency union point of view, there could even be advantages in requiring the opposite-countries with different cyclical positions may benefit from the resulting counteracting influences-the case in favor of the criterion is clearly strong: cyclical convergence, in particular to the extent that it implies convergence in policies, would indicate

\section{${ }^{55}$ Prepared by Zenon Kontolemis and Hossein Samiei.}

${ }^{56}$ Indeed it has been suggested by commentators that all five criteria are too broad and vague to have any real operational content, see Buiter (1999). See also Fetherston (1998) for a discussion of cyclical convergence as a criterion for EMU entry.

${ }^{57}$ See, for example, Engle and Kozicki (1993), Christodoulakis, Dimelis, and Kollintzas (1995), Artis, Kontolemis, and Osborn (1997), and, Artis and Zhang (1995). 
Figure 1. Selected countries: Real GDP
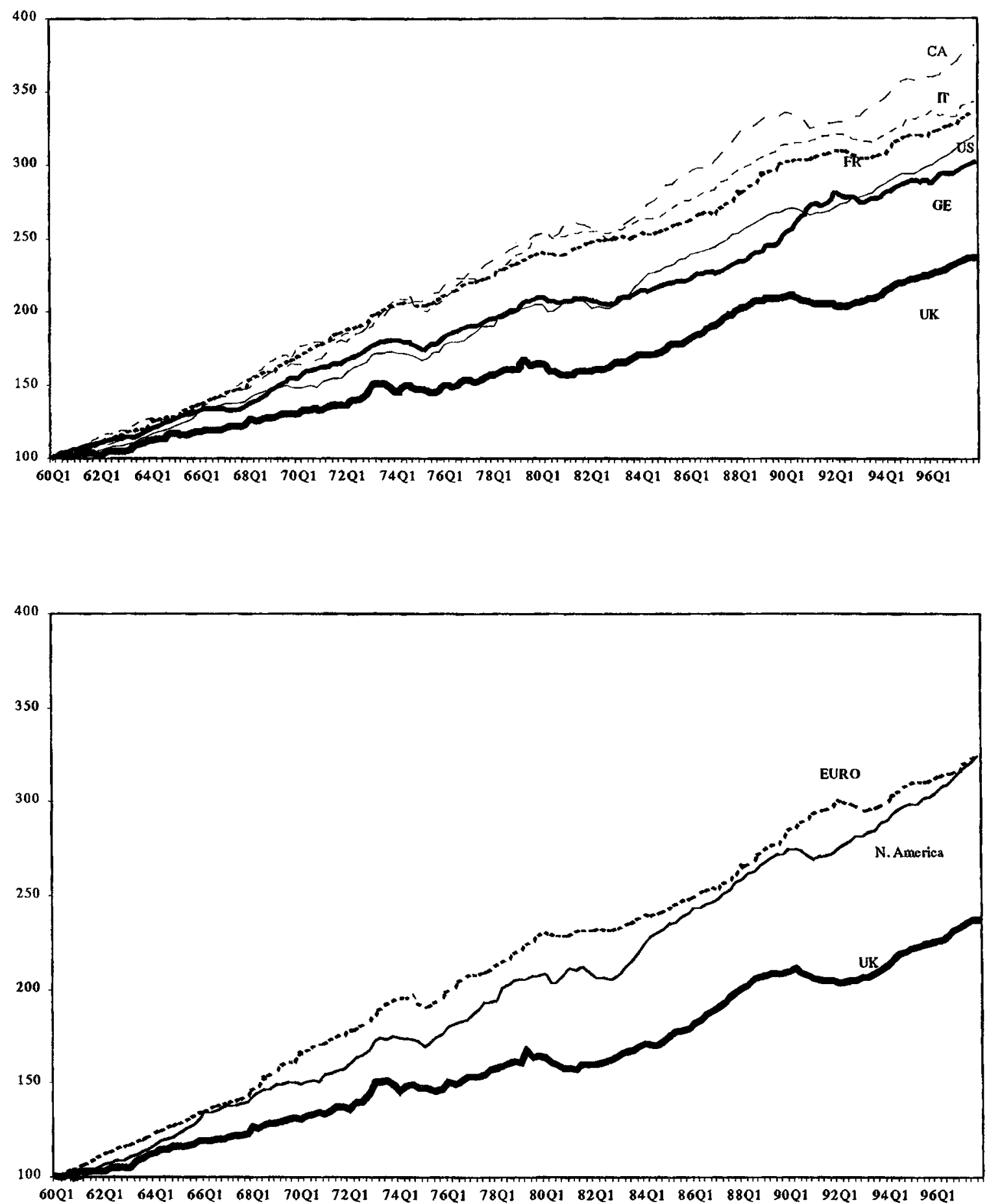
suitability for currency unification; it would also help ensure a smooth transition by diminishing the likelihood of exchange rate misalignment caused by cyclical differences. There is also a definitional issue that the Chapter does not discuss. The convergence criterion, although more transparent than the other four, still leaves plenty of room for interpretation. For example, it is not entirely clear whether the criterion simply requires that at the time of entry the United Kingdom and the EMU countries be in a similar cyclical position, or whether it addresses the more structural of issue of whether the cycles should become fundamentally more synchronized, both in relation to length and amplitude. While the primary aim of this Chapter is to throw light on the latter aspects of the problem - on the assumption that the latter condition implies the former in the medium term-, clearly the short-term cyclical issue remains of immediate relevance to policy makers.

108. The Chapter first provides new evidence on the main features of the U.K. business cycle, in order to put the convergence criterion in the relevant context. The results show that the business cycle in the United Kingdom is more correlated with those in North America than in Europe. They also demonstrate that the U.K. business cycles have not only been out of line with those in major European countries, but they have also been, on average, deeper and more volatile than elsewhere.

109. The Chapter then attempts to identify factors that have contributed to cyclical fluctuations in the United Kingdom in order to assess the areas where policy actions may be required to enhance the likelihood of convergence. Cycles in the U.K. may differ from those on the continent for principally three reasons: different policies or exogenous variables, different transmission mechanisms, and different idiosyncratic shocks. In algebraic terms suppose that output reacts to policy (and exogenous) variables in the following fashion: $y_{i, t}=A_{i} Z_{i, t}+\eta_{i, t}+e_{t}$ where the subscript I refers to country, $Z_{t}$ is a vector of the explanatory variables, $\eta_{i, t}$ an idiosyncratic or country specific shock, and $e_{t}$ is a common shock. In this framework differences in policies, in transmission mechanisms, and in country-specific shocks are, respectively, reflected in differences in $Z_{b} A_{i}$, and $\eta_{i, t}$. This Chapter examines only the role of policy and exogenous variables in this regard. Clearly, different transmission mechanisms and/or idiosyncratic shocks could also play important roles. ${ }^{58}$

110. A cointegrating VAR model of the U.K. economy is estimated in order to examine the role of policies and the exchange rate in the U.K. business cycle. The estimation results provide evidence that monetary variables and the exchange rate have significantly contributed to GDP fluctuations. For example, the downturn during 1990-92 is largely explained by the interest rate and the exchange rate. These results emphasize the need, recognized by the authorities, for actively pursuing policies that will bring the U.K. economy closer to those on the continent and to contain fluctuations in the exchange rate. To this end, the government's

\footnotetext{
${ }^{88}$ See Christodoulakis, Dimelis and Kollintzas (1995) for evidence on idiosyncratic shocks in European countries; and Britton and Whitely (1997) and Ramaswamy and Sloek (1997), and references therein, on the transmission mechanism.
} 
efforts to strengthen the medium-term focus of monetary and fiscal policies seem appropriate. ${ }^{59}$ The European Commission's recent assessment of the U.K. economic policies also argues that these are fully consistent with prospective membership of the euro single currency.

111. The role of the exchange rate is clearly crucial: its volatility has been significant in causing growth fluctuations, implying that convergence is unlikely if circumstances that allow the exchange rate to have large swings continue; and the U.K.'s brief experience with the ERM illustrates the harmful effects of entering a single currency at a wrong rate. There is, therefore, the issue of how to reduce volatility in the exchange rate and how to ensure that an appropriate exchange rate is achieved prior to EMU entry. The option of joining an exchange rate mechanism as a preliminary step to joining EMU is not considered viable by the U.K. authorities. While the medium-term orientation of fiscal and monetary policies may help stabilize the exchange rate, specific actions close to the time of entry may also be required to influence the entry rate. The dilemma facing the policy makers is that such action, in particular if it implies procyclical monetary policy, could exacerbate cyclical differences with Europe and jeopardize the medium-term objectives of policies.

112. Notwithstanding the case for policies that enhance the likelihood of convergence, the estimation results may also be looked at from the opposite angle. One could argue that, given the historical divergence between cycles in the United Kingdom and those on the continent and given the drawbacks of delaying the entry significantly, applying a reasonable degree of pragmatism in evaluating the cyclical convergence criterion may be warranted. Moreover, stability-oriented policies are only likely to lower cyclical fluctuations over the medium term and may not necessarily weaken the impact of idiosyncratic shocks.

\section{B. Properties of the U.K. Business Cycle}

113. Decomposing GDP into cycles and other components is inevitably hampered by definitional uncertainties. In general terms a time series may comprise of three types of components: trends, cycles - both of which may include stochastic terms-, and shocks. The problem is that there are no generally acceptable methods to separate these. Moreover, different methods often yield apparently different results. While one may set criteria that help in choosing from among the various methods, depending on the particular features of the cycle that one is interested in, there is clearly a great degree of arbitrariness. ${ }^{60}$

\footnotetext{
${ }^{59}$ See H.M. Treasury (1998), which suggests that macroeconomic policy has had a destabilizing impact on the U.K. economy.

${ }^{60}$ See Canova (1998), for a critical discussion of the arbitrariness inherent in using various detrending methods; and Burnside (1998) for a defense of the conventional methodology.
} 
114. This section examines the U.K. business cycle and its relation to those in other major countries, using two distinct approaches. The first approach uses the Hodrick-Prescott (HP) filter to define "growth cycles" as deviations from the trend. This concept of the cycle is closely related to the output gap. An HP filter (with a parameter of 1600) is applied to quarterly GDP data for the United Kingdom, United States, Canada, Germany, France, and Italy. ${ }^{61}$

115. The second method identifies and compares business cycle turning points using a simple 2-consecutive change rule (see below). The method allows a separate examination of the characteristics of expansions and contractions while avoiding the de-trending component of methods such as the HP filter, which may, under certain conditions, induce spurious cycles (see King and Rebello, 1993, and Osborn, 1995, for example).

\section{Synchronization between cycles}

116. Table 1 reports coefficients of correlation between growth cycles in different countries, based on the HP filter. It demonstrates that the cycle in the United Kingdom is more correlated with those in the United States and Canada than in Germany, France or Italy. ${ }^{62}$ The table also shows that correlation between the United States and Canada, on the one hand, and between France, Germany and Italy, on the other hand, are strong. ${ }^{63}$

Table 1: GDP Correlation Coefficients for Growth Cycles (HP Filter)

\begin{tabular}{lllllll}
\hline & UK & US & CA & FR & GE & IT \\
\hline UK & & & & & & \\
US & 1.00 & & & & & \\
CA & 0.58 & 1.00 & & & & \\
FR & 0.54 & 0.73 & 1.00 & & & \\
GE & 0.47 & 0.31 & 0.27 & 1.00 & & \\
IT & 0.25 & 0.32 & 0.19 & 0.48 & 1.00 & \\
Euro & 0.23 & 0.21 & 0.26 & 0.55 & 0.29 & 1.00 \\
North America & 0.38 & $\ldots$ & $\ldots$ & $\ldots$ & $\ldots$ & $\ldots$ \\
\hline
\end{tabular}

\footnotetext{
${ }^{61}$ The data for various countries, GDP at constant prices, was retrieved from the IMF database. It is quarterly and covers the period 1960:1-1997:4.

${ }^{62}$ The Chapter does not report results on industrial production growth cycles, which tend to be more idiosyncratic. Evidence for industrial production is provided by Artis and Zhang(1995).

${ }^{63}$ The table also presents correlation coefficients between the United Kingdom and aggregates for North America (USA and Canada) and the Euro area (France, Germany and Italy). Aggregation is carried out using PPP weights from the WEO database.
} 
117. Table 2 reports results using business cycle turning points. A binary time series variable is defined for each country, denoting periods of expansion with ones and contraction with zeros. Turning points are obtained if any two or more consecutive observations are above the mean growth (upswing) or below the mean (downswings). The classification into binary zero-one variables makes similarities and differences appear more pronounced. These binary variables may be used to construct conventional contingency tables and Pearson's contingency coefficients. ${ }^{64}$ The results reported in Table 2 are in line with those obtained using the HP filter: the U.K. business cycle is relatively more correlated with those in North America than in Europe; that there is considerably more correlation within Europe than between the United Kingdom and Europe; and finally that there is very little correlation between the European countries' business cycles and those in either the United States or Canada.

\section{Volatility of cycles}

118. The U.K. business cycles have not only been out of line with those in major European countries, they have also been, on average, deeper and more volatile than elsewhere. The variance of U.K.'s GDP growth (over the period 1960-97) is significantly higher than those in France, Germany, and Italy. For example, it is twice as high as that in France (Table 3). In addition, as a result of the higher frequency and severity of recessions, the cumulative decline during all downturns (defined as two consecutive absolute declines) has also been higher in the United Kingdom (Table 4); and GDP in the United Kingdom has increased by a smaller

\footnotetext{
${ }^{64} 2 \times 2$ contingency tables for a pair (country $I$, country $j$ ) over the sample period are constructed recording expansion/contraction frequencies, denoted by $n_{00}, n_{01}, n_{10}$ and $n_{11}$. A zero subscript denotes a downturn and $a$ one an upturn. Thus, $n_{00}$ denotes the number of coincidence of downturns, and so on. To examine correlation using this method, the Pearson's contingency coefficient is used. This is expressed as a percentage and corrected to lie in the range 0 to 100 . This coefficient is defined as:
}

$$
\begin{gathered}
C C=\sqrt{\frac{\hat{\chi}^{2}}{N+\hat{\chi}^{2}}} \\
\text { where } \hat{\chi}^{2}=\sum_{i=0}^{1} \sum_{j=0}^{1} \frac{\left(n_{i j}-n_{i .} n_{j} / N\right)^{2}}{n_{i .} n_{j} / N}
\end{gathered}
$$

For a $2 \times 2$ table, this maximal value is $\sqrt{1} 1 / 2$ and one obtain a statistic which lies between 0 and 100 , namely coir. This corrected contingency coefficient has a straightforward interpretation as a correlation measure (for details see Sachs, 1984 and Siege and Castellan, 1988). 
Table 2: Counts and Correlation of Business Cycles Regimes (relative to Mean) for the United Kingdom and Germany 1/

\begin{tabular}{|c|c|c|c|c|c|}
\hline & N00 & N01 & N10 & N11 & $\begin{array}{l}\text { Cramer-C } \\
\text { coefficient }\end{array}$ \\
\hline \multicolumn{6}{|c|}{ United Kingdom } \\
\hline US & 54 & 18 & 19 & 57 & 0.63 \\
\hline $\mathrm{CA}$ & 45 & 27 & 23 & 53 & 0.43 \\
\hline FR & 39 & 33 & 29 & 47 & 0.22 \\
\hline GE & 40 & 32 & 33 & 43 & 0.17 \\
\hline $\mathrm{IT}$ & 46 & 26 & 41 & 35 & 0.14 \\
\hline \multicolumn{6}{|c|}{ Germany } \\
\hline US & 46 & 27 & 27 & 48 & 0.36 \\
\hline $\mathrm{CA}$ & 45 & 28 & 23 & 52 & 0.41 \\
\hline FR & 56 & 17 & 12 & 63 & 0.73 \\
\hline IT & 57 & 16 & 30 & 45 & 0.51 \\
\hline \multicolumn{6}{|c|}{ United Kingdom vs North America, EURO } \\
\hline North America & 52 & 20 & 19 & 57 & 0.60 \\
\hline Euro & 37 & 35 & 29 & 47 & 0.18 \\
\hline \multicolumn{6}{|c|}{ North America vs Euro } \\
\hline North America & 44 & 25 & 22 & 55 & 0.45 \\
\hline
\end{tabular}

1/ A downturn (upturn) regime is denoted by 0 (or 1 ) and is defined as two consecutive declines (increases) below (above) the mean. $\mathrm{Nij}, \mathrm{i}, \mathrm{j}=0,1$ denotes the number of occurances (quarters) of regime $i$ in UK (or Germany in the middle panel) and regime in the other countries. 
Table 3: GDP Growth-Descriptive Statistics (1960:1-1997:4) 1/

\begin{tabular}{|c|c|c|c|c|c|c|c|c|}
\hline & UK & US & $\mathrm{CA}$ & FR & GE & IT & Euro & N.America \\
\hline Mean & 0.57 & 0.76 & 0.88 & 0.80 & 0.72 & 0.81 & 0.76 & 0.80 \\
\hline Variance & 1.13 & 0.86 & 0.96 & 0.54 & 0.62 & 1.07 & 0.41 & 0.77 \\
\hline Skewness & $0.47^{* *}$ & -0.24 & $0.45^{* *}$ & 0.21 & -0.21 & $0.55^{* *}$ & $-0.62^{* *}$ & -0.24 \\
\hline Excess Kurtosis & $2.67^{* *}$ & $1.14^{* *}$ & $0.90^{* *}$ & $1.92 * *$ & 0.21 & $2.73 * *$ & 1.22 & $1.21 * *$ \\
\hline
\end{tabular}

$1 / * *$ denote significance at 5 percent level

Table 4: Cumulative Change in GDP

(In percent) $1 /$

\begin{tabular}{lrrrrrr}
\hline & UK & U.A & CA & FR & GE & IT \\
\hline (1) Cumulative Growth & 83.1 & 115.0 & 130.0 & 115.9 & 103.5 & 114.5 \\
$\begin{array}{l}\text { (2) Cumulative decline } \\
\text { during recessions }\end{array}$ & -16.1 & -12.5 & -9.6 & -3.6 & -8.3 & -10.3 \\
Ratio (2)/(1)*100 & 19.1 & 10.9 & 7.4 & 3.1 & 8.0 & 9.03 \\
Number of Recessions & 9.0 & 6.0 & 3.0 & 2.0 & 4.0 & 6.0 \\
\hline
\end{tabular}

1/ Based on 2-consecutive change rule (below/above zero)

degree over the period ( 83 percent, compared with 115 per cent in the United States, 130 percent in Canada, and 115 per cent in France. $)^{65}$

119. It is also interesting to compare the three "common" cycles for the major industrial countries over this period, with downturns during 1973-75, 1980-82, 1990-93. Table 5

${ }^{65}$ Taking France as an example, the ratio of the cumulative decline of GDP in the United Kingdom, during all recessions to total growth was 19.1 compared with 3.1 per cent for France. 
compares the duration of the downturns and the decline in GDP for each recession. ${ }^{66}$ This information reveals the longer duration of the downturns in the United Kingdom, in comparison with the other countries. For example the last recession in the beginning of the 1990s lasted 8 quarters in the United Kingdom compared with 3 in the United States, 4 in Germany, and 5 in Italy.

Table 5: Duration and Depth of Major Recessions - GDP $1 /$

\begin{tabular}{lcccccc}
\hline & \multicolumn{2}{c}{$1973-75$} & \multicolumn{2}{c}{$1980-83$} & \multicolumn{2}{c}{$1990-93$} \\
& $\begin{array}{l}\text { Duration } \\
\text { (quarter) }\end{array}$ & $\begin{array}{c}\text { Depth } \\
\text { (percent) }\end{array}$ & $\begin{array}{c}\text { Duration } \\
\text { (quarter) }\end{array}$ & $\begin{array}{c}\text { Depth } \\
\text { (percent) }\end{array}$ & $\begin{array}{c}\text { Duration } \\
\text { (quarter) }\end{array}$ & $\begin{array}{c}\text { Depth } \\
\text { (percent) }\end{array}$ \\
UK & 2 & -3.8 & 6 & -4.6 & 8 & -3.6 \\
US & 3 & -3.1 & 2,4 & $-2.5,-3.0$ & 3 & -2.0 \\
CA & $\ldots$ & $\ldots$ & 2,6 & $-1.3,-5.2$ & 4 & -3.0 \\
FR & 2 & -1.9 & $\ldots$ & $\ldots$ & 2 & -1.6 \\
GE & 4 & -3.2 & 5 & -1.7 & 4 & -2.1 \\
IT & 4 & -4.1 & 4,2 & $-1.0,-0.6$ & 5 & -1.9 \\
\hline
\end{tabular}

1/ Cycles defined with 2-consecutive change rule (below/above zero)

\section{Policy Variables and the Cycle: A Structural VAR Analysis}

120. This section estimates a system of co-integrating structural VAR in order to assess the contributions of policies and the exchange rate to business cycles in the United Kingdom. ${ }^{67}$

${ }^{66}$ Notice that some countries, the United States and Canada in particular, experienced two recessions during the period 1980-83 and the information for both is included in the table. This result for the United States is in line with the official NBER classification of two short recessions in that period.

${ }^{67}$ A number of papers estimate VAR models for the U.K. economy. Lane and Van Den Heuvel (1998) estimate a VAR model which includes data on GDP growth, unemployment, inflation, the nominal effective exchange rate and short- and long-term interest rates. Henry and Pesaran (1993) estimate a VAR model and show that M0, the narrow definition of money, contains useful information about the future price level. Using a more structural approach, Garratt et al (1997) estimate a small VAR model for the UK economy. Their model is based on long-run 
Any such exercise by nature is tentative because of the large degree of arbitrariness that exists in choosing from among competing VAR specifications. The principal source of arbitrariness is the fact that restrictions need to be imposed to identify the system, thus inhibiting thorough cross comparison of alternative VARs.

121. We use the Mundell-Flemming model to provide a broad framework for analysis: in the goods market output $(y)$ is determined by the real interest rate $(I-\pi)$, the real effective exchange rate, defined as the price of domestic currency times relative prices (e), real money balances ( $\mathrm{m}-\mathrm{p}$ ), and real government expenditure ( $\mathrm{g}$ ); in the money market supply of money is set equal to demand for money, expressed as a function of income and the interest rate; and in the capital market, the interest rate parity condition, for given exchange rate expectations and relative prices, implies a relationship between the exchange rate and domestic and foreign interest rates (all variables are in logarithms, except for the interest rate): ${ }^{.8}$

$$
\begin{gathered}
y=\Phi(i-\pi, e, m-p, g) \\
m-p=f(y, i) \\
e=h(i, i *)
\end{gathered}
$$

122. The econometric methodology followed here has been reviewed extensively in the academic literature-see for example Johansen (1988a,b and 1995), Hendry (1995), Doornik and Hendry(1997) and references therein. Denoting by $z_{\imath}$ the vector which includes all the variables of interest, the VAR system takes the form:

$$
z_{t}=\sum_{i=1}^{m} \pi_{i} z_{t-i}+v_{t}
$$

This can be written in the error correction form as:

$$
\Delta z_{t}=\sum_{i=1}^{m-1} \delta_{i} \Delta z_{t-i}+\alpha\left(\beta^{\prime} z_{t-1}+\gamma^{\prime} q_{t}\right)+v_{t}
$$

if $\alpha \beta^{\prime} z_{t-1}$ is $I(0)$, that is if there exists at least one co-integrating vector between the variables in $z_{\boldsymbol{t}}$. The term in parentheses represents the error correction mechanism, with $\beta$ the cointegrating vector and $\alpha$ measuring responsiveness to error correction (or to the extent of long-term disequilibrium in the system). Deterministic effects are included in $\gamma^{\prime} q_{t}$. Once

\footnotetext{
${ }^{67}$ (...continued)

relations, implied by economic theory, and embodied in an otherwise unrestricted VAR framework.

${ }^{68} \mathrm{~A}$ relationship between the two latter variables could also arise if the authorities respond to changes in the exchange rate by adjusting monetary policy.
} 
the model is estimated and the number of co-integrating relationships established, the task is to identify unique co-integrating relationships that are consistent with economic theory.

123. The model includes real money, real GDP, the nominal short-term interest rate, the real effective exchange rate, and real government expenditure. ${ }^{69}$ All variables are difference stationary. Thus, a VAR in levels-with 5 lags and a constant term-is estimated. This is referred to below as the $\mathrm{I}(1)$ system. The sample period is 1963Q1-97Q4. F tests confirm that all five lags are significant for the system as a whole and therefore retained in the second step which begins by testing for co-integration. The supporting diagnostics (not reported here) show no evidence of autocorrelation or heteroskedasticity, but reveal the absence of error normality. The latter problem largely-but not totally-disappears by adding dummies to account for sterling's sharp fall in 1992Q4.

124. Testing for co-integration is carried out using the Johansen procedure (see Johansen, 1988a,b). Both the maximum eigenvalue ( $\max$ ) and trace statistics (tr), without and with an adjustment for degrees of freedom - dof -- as suggested by Reimers(1992), are tabulated in the Table 6 . The tests reveal three, possibly four, long-run relationships. Visual inspection suggests that only the first three are stationary and consequently we proceed with the hypothesis that the rank of the $\Pi$ matrix is three. The system is re-estimated with the rank restriction imposed. ${ }^{70}$

\footnotetext{
${ }^{69} \mathrm{GDP}$ (real GDP, 1995 prices), money M4, nominal interest rate (3-month, treasury bill rate), e (real effective exchange rate) and expenditure is (smoothed) government spending. Money and government expenditure are deflated by the retail price index. The variables are in logarithms, except for the interest rate. Including a price inflation (to allow for the separation of real and nominal interest rate) did not appear to improve the estimation results and this variable was not included in the results reported here.

${ }^{70}$ Each row of the standardized beta eigenvector matrix, not reported here, includes each cointegrating vector that spans the co-integrating space.
} 
Table 6: Tests for Co-integration 1/

\begin{tabular}{ccccccc}
\hline Ho:rank $=\mathrm{p}$ & $\max$ & max-dof & $\begin{array}{c}95 \\
\text { (percent) }\end{array}$ & Trace & Trace-dof & $\begin{array}{c}95 \\
\text { (percent) }\end{array}$ \\
\hline $\mathrm{p}=0$ & $48.4^{* *}$ & $39.2^{*}$ & 34.4 & $128.3^{* *}$ & $104.0^{* *}$ & 76.1 \\
$\mathrm{p} \leq 1$ & $34.2^{* *}$ & 27.7 & 28.1 & $79.8^{* *}$ & $64.7^{* *}$ & 53.1 \\
$\mathrm{p} \leq 2$ & $24.3^{*}$ & 19.7 & 22.0 & $45.6^{* *}$ & $37.0^{*}$ & 34.9 \\
$\mathrm{p} \leq 3$ & 13.2 & 10.7 & 15.7 & $21.3^{*}$ & 17.3 & 20.0 \\
$\mathrm{p} \leq 4$ & 8.0 & 6.5 & 9.2 & 8.0 & 6.5 & 9.2 \\
\hline
\end{tabular}

$1 /$ Restricted intercept, no trend

125. The standardized co-integrating vectors obtained are just one representation of the cointegrating space and any linear combination is also admissible. In other words, the long-run relationships are not uniquely identified. Consequently, economic theory should guide us in deciding on a suitable representation that uniquely identifies the system.

126. To identify the long-run relationships we need at least nine restrictions on the parameters. ${ }^{71}$ The theoretical model imposes five restrictions on the $\beta$ matrix, and normalization imposes another three. The remaining one restriction is imposed on $\alpha$. These restrictions together allow the identification of the system. Additionally, seven over identifying restrictions are imposed on the elements of $\alpha$ as implied by the statistical significance of the entries of this matrix (see Table 7). These are tested jointly and not rejected (LR-test $\chi^{2}(7)=$ 10.56 [0.1590] - see Hendry and Doornik, 1997, for details of the test.)

127. The estimation yields the following set of co-integrating relationships (corresponding to $\boldsymbol{\beta}^{\prime} \mathbf{z}_{\mathbf{t}}$ relationships described above):

$$
\begin{aligned}
& C_{1}=y-0.26 m+0.17 i+0.22 e-0.34 g-4.4 \\
& C_{2}=m-1.8 y+6.2 i+3.0 \\
& C_{3}=i+0.6 e-2.9
\end{aligned}
$$

\footnotetext{
${ }^{71}$ It has to be noted that the issue of imposing restrictions for identification and testing the overidentifed restrictions is not always straightforward, especially when restrictions on $\alpha$ are also involved. It is sometimes possible that some restrictions are not binding (when, for example, restrictions in $\beta$ are "absorbed" by $\alpha$ ). In that case identification requires extra restrictions. Accordingly the degrees of freedom in testing for over-identified restrictions also needs to be adjusted.
} 
Table 7: Dynamic Equations with Error Correction Terms-Estimated by FIML 1/

\begin{tabular}{|c|c|c|c|c|c|}
\hline & $\Delta m$ & $\Delta y$ & $\Delta i$ & $\Delta e$ & $\Delta g$ \\
\hline$\Delta m_{t-1}$ & $0.393^{*}$ & 0.095 & 0.017 & -0.043 & 0.054 \\
\hline$\Delta m_{t-2}$ & 0.028 & $0.152^{*}$ & 0.133 & -0.280 & $-0.206^{*}$ \\
\hline$\Delta m_{t-3}$ & 0.142 & 0.111 & 0.090 & -0.017 & 0.042 \\
\hline$\Delta m_{t-4}$ & 0.178 & 0.004 & -0.059 & 0.193 & $0.273^{*}$ \\
\hline$\Delta y_{t-1}$ & -0.101 & $-0.180^{*}$ & -0.119 & 0.466 & $-0.231^{*}$ \\
\hline$\Delta y_{t-2}$ & 0.094 & $-0.205^{*}$ & -0.041 & -0.346 & -0.150 \\
\hline$\Delta y_{t-3}$ & -0.157 & -0.018 & 0.133 & -0.017 & $-0.284^{*}$ \\
\hline$\Delta y_{1-4}$ & -0.163 & $-0.276^{*}$ & -0.110 & 0.252 & $-0.262^{*}$ \\
\hline$\Delta i_{t-1}$ & $-0.287^{*}$ & 0.118 & 0.153 & $0.949^{*}$ & -0.157 \\
\hline$\Delta i_{t-2}$ & -0.145 & -0.050 & -0.080 & 0.054 & 0.176 \\
\hline$\Delta i_{t-3}$ & -0.233 & 0.110 & -0.060 & 0.102 & -0.156 \\
\hline$\Delta i_{t-4}$ & $0.295^{*}$ & -0.024 & -0.022 & 0.045 & $0.262^{*}$ \\
\hline$\Delta e_{t-1}$ & $-0.103^{*}$ & 0.009 & 0.002 & $0.285^{*}$ & $-0.066^{*}$ \\
\hline$\Delta e_{t-2}$ & -0.009 & -0.010 & 0.011 & -0.064 & 0.051 \\
\hline$\Delta e_{t-3}$ & -0.064 & 0.032 & 0.036 & -0.040 & -0.035 \\
\hline$\Delta e_{t-4}$ & -0.012 & -0.015 & 0.014 & -0.009 & 0.004 \\
\hline$\Delta g_{t-1}$ & -0.190 & $-0.203^{*}$ & 0.129 & -0.133 & 0.127 \\
\hline$\Delta g_{t-2}$ & -0.120 & -0.113 & 0.007 & 0.197 & $0.298^{*}$ \\
\hline$\Delta g_{t-3}$ & $-0.316^{*}$ & -0.120 & 0.053 & 0.014 & -0.194 \\
\hline$\Delta g_{1-4}$ & 0.150 & 0.088 & $0.370^{*}$ & -0.518 & 0.033 \\
\hline$C 1_{k-1}$ & $0.120^{*}$ & $-0.126^{*}$ & $0.188^{*}$ & & \\
\hline$C 2_{t-1}$ & $-0.025^{*}$ & $-0.016^{*}$ & & & $-0.021^{*}$ \\
\hline$C 3_{t-1}$ & & & $-0.095^{*}$ & & \\
\hline$\sigma$ & 0.013 & 0.009 & 0.009 & 0.032 & 0.011 \\
\hline
\end{tabular}

$1 /$ Indicates that the variable is significant at the 10 per cent level. 
The long-run coefficients implied by the cointegrating equations have signs that are consistent with the framework described above. Goods market equilibrium, equation $\mathrm{C}_{1}$, suggests that output is positively related to money and government expenditure, and negatively to the interest rate and the exchange rate. Money market equilibrium, $\mathrm{C}_{2}$, implies that demand for money is negatively to the interest rate and positively to income. Finally, equation $\mathrm{C}_{3}$ could loosely be interpreted as an interest rate parity condition, such that the interest rate adjusts in the opposite direction to the exchange rate.

128. Given that three co-integrating relationships exist, the system can be re-written in first differences, as in equation (1), with co-integrating vectors $C_{1}, C_{2}$, and $C_{3}$ as error-correction terms. The estimation results for this equation, using full-information-maximum likelihood, are reported in Table $7 .{ }^{72}$

The estimated equation for the growth of GDP, as reported in Table 7, is:

$$
\Delta y=-0.126 C_{1, t-1}-0.016 C_{2, t-1}+\text { Other terms }
$$

129. This equation tracks adequately the business cycle fluctuations in GDP (Figure 2, top panel). The correlations of the actual and fitted values for this equation is 0.58 , compared with 0.21 obtained by a simple AR(4) process.

130. The results suggest an important role for monetary conditions in explaining fluctuations in economic growth. This is illustrated, for example, by the strong feedback to disequilibrium in the goods market, as shown by $\mathrm{C}_{1}$, which mainly reflects changes in monetary conditions (movements in the interest rate and the exchange rate). It is, perhaps more clearly, also illustrated in Figure 2, bottom panel, which plots actual and predicted GDP growth in a model which removes the interest rate and the exchange rate. In this case, the correlation between the actual and fitted values falls to 0.39 . It is obvious, for example, that the downturn during $1990-92$ is completely missed by this model.

\section{Conclusions}

131. This Chapter provides evidence in support of the view that output fluctuations in the United Kingdom have been larger than in other major industrial countries, and relatively more in line with those in North America than those in major European countries. In addition, estimation results from a cointegrating VAR system identify important roles for the interest rate and the exchange rate in generating output fluctuations in the United Kingdom. This is particularly the case during the downturn of the early 1990 s and the upswing that followed it.

\footnotetext{
${ }^{72}$ The model can be simplified and re-estimated further, but although sequential tests of model reduction allow considerable simplification of the system, the simplified system seems to suffer from serial correlation.
} 
Figure 2. United Kingdom: Actual and predicted GDP growth
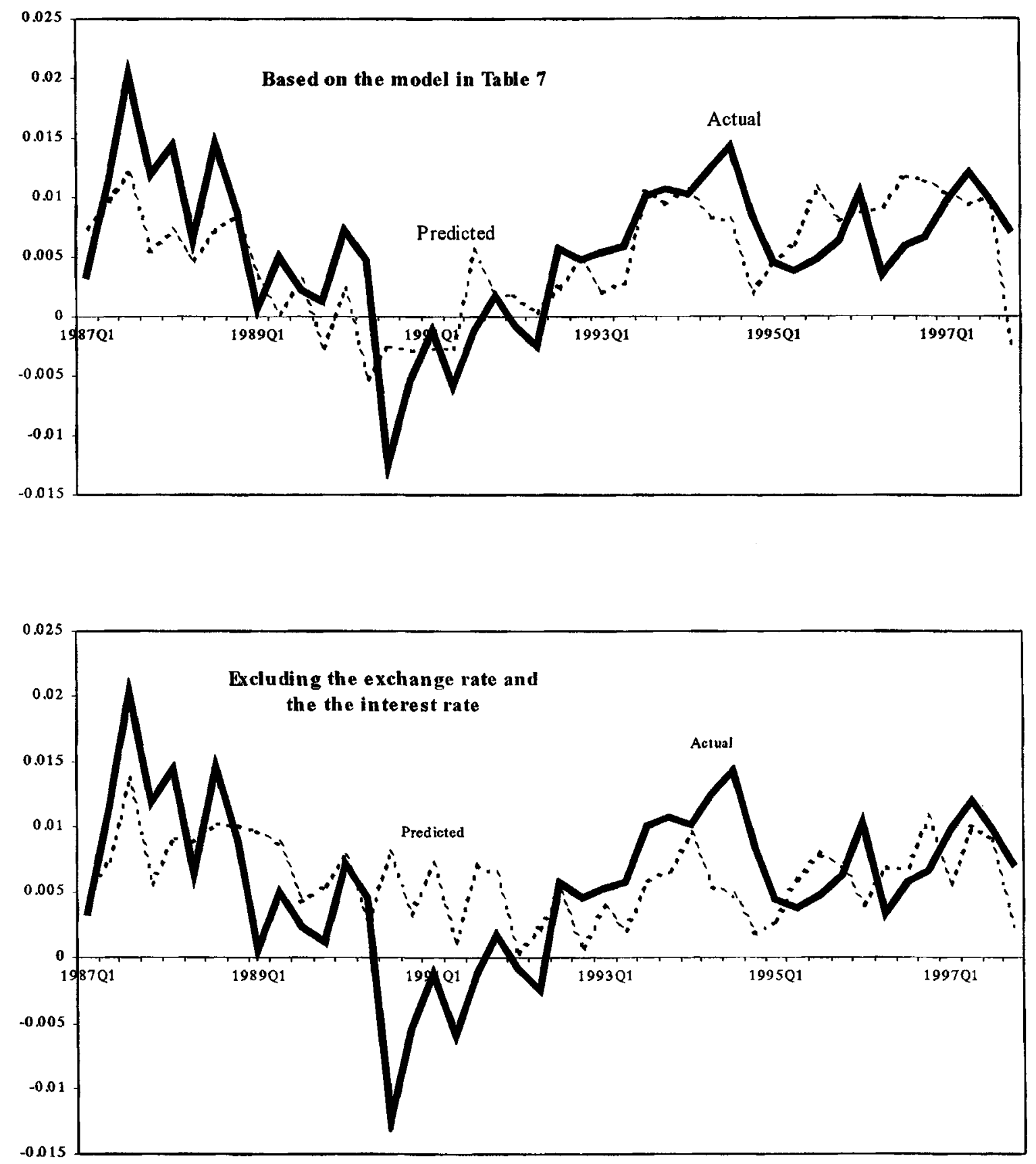
132. The implication is that to moderate output fluctuations and increase the likelihood of cyclical convergence there is a need to pursue more stable policies, and to contain fluctuations in the exchange rate. To this end, the government's efforts to strengthen the medium-term focus of monetary and fiscal policies seem appropriate. At the same time policy makers face a dilemma in that while more stable policies may in the long term help stabilize the exchange rate, this may not necessarily be the case in the short-term. For example, reducing exchange rate misalignment in the short-term may imply procyclical monetary policy, which could exacerbate cyclical divergence and jeopardize the medium-term objectives of policies.

133. While the analysis clearly illustrates the cost (in terms of lower likelihood of convergence) of policies that destabilize output, one may also argue that given the historical properties of the U.K. cycle and given the drawbacks of delaying the entry significantly, it may be necessary to apply a reasonable degree of pragmatism in evaluating the cyclical convergence criterion, in particular if countries such as Ireland, Spain, and Portugal, despite their cyclical positions, successfully take part in EMU. Clearly, however, this should not be at the expense of attempts to strengthen the likelihood of convergence, which would indicate suitability for currency unification and would help ensure a smooth transition. 


\section{REFERENCES}

Artis, M. J., Kontolemis, Z.G., and Osborn, D.R., 1997, "Business Cycles for the G7 and European Countries", The Journal of Business, vol. 70, no.2, 249-279.

Artis, M.J. and Zhang, W., 1995, "International Business Cycles and the ERM: Is there a European Business Cycle?", International Journal of Finance and Economics, 2:1-16.

Britton, E. and Whitley, J., 1997, "Comparing the monetary transmission mechanism in France, Germany, and the United Kingdom: Some issues and results", Bank of England Quarterly Bulletin, (May), Vol. 37, No. 2.

Buiter, W. B., 1999, "Britain and EMU”, Bank of England mimeo., February.

Burnside, C., 1998, "Detrending and Business Cycle facts: A comment", Journal of Monetary Economics, 41:513-532.

Canova, F., 1998, "Detrending and Business Cycle facts", Journal of Monetary Economics, 41:475-512.

Christodoulakis, N., Dimelis, S. and Kollintzas, T., 1995, "Comparisons of Business Cycles in the EC: Idiosyncrasies and Regularities", Economica, 62, 1-27.

Doornik, J.A. and Hendry, D.F., 1997, Modelling Dynamic Systems using PC Fiml 9.0 for Windows, International Thompson Publishers.

Engle, R.F. and Kozicki, S., 1993, "Testing for Common Features", Journal of Business and Economic Statistics, vol.11, no.4, 369-395 (with discussion).

Fetherston, M., 1998, "Ireland and the United Kingdom: Diverging Approaches to EMU", mimeo., European Department, IMF.

Garratt, A. Lee, K., Pesaran, M.H. and Shin, Y., 1997, “A Long Run Structural VAR Model of the UK Economy", mimeo, University of Cambridge.

Hendry, D.F., 1995, Dynamic Econometrics, Oxford:Oxford University Press.

H.M. Treasury, 1998, "Delivering Economic Stability: Lessons from Macroeconomic Policy Mix", The Pre-Budget Report, November.

Johansen, S., 1988a, "Statistical Analysis of Cointegrating Vectors", Journal of Economic Dynamics and Control 12:231-54. 
—_, 1988b, "Maximum Likelihood Estimation and Inference on Cointegration-with Applications to the Demand for Money", Oxford Bulletin of Economics and Statistics 52:169-210.

- 1992, "Testing Weak Exogeneity and the Order of Cointegration in U.K. Money Demand", Journal of Policy Modelling 14:313-34.

- 1995, Likelihood-Based Inference in Cointegrated Vector Autoregressive Models, Oxford:Oxford University Press.

King, R.G. and Rebello, S.T., 1993, "Low frequency filtering and real business cycles", Journal of Economic Dynamics and Control, 17:207-31.

Obstfeld, M. And Peri, G., 1998, "Regional non-adjustment and fiscal policy", Economic Policy, April:207-259, with discussion.

Osborn, D.R., 1995, "Moving Average de-trending and the analysis of business cycles", Oxford Bulletin of Economics and Statistics, 57:547-58.

Ramaswamy, R. And T. Sloek, 1997, "The real effects of monetary policy in the European Union: What are the differences?" IMF Working Paper 97/160 (Washington: International Monetary Fund).

Sachs, L., 1985, Applied Statistics, Springer-Verlag.

Siegel, S. And Castellan, N.J.,1988, Nonparametric Statistics, McGraw-Hill. 
Table A1. United Kingdom: Real Output and Its Major Components at Constant Factor Cost

(Percentage change over preceding year)

\begin{tabular}{|c|c|c|c|c|c|c|c|}
\hline & $\begin{array}{c}1990 \\
\text { Weights }\end{array}$ & 1992 & 1993 & 1994 & 1995 & 1996 & 1997 \\
\hline Agriculture, forestry and fishing & 19 & 3.8 & -7.9 & -0.7 & -1.4 & -1.6 & -2.4 \\
\hline Total production and construction & 350 & -0.6 & 1.6 & 5.1 & 1.3 & 1.1 & 1.1 \\
\hline Manufacturing & 232 & -0.1 & 1.4 & 4.7 & 1.5 & 0.4 & 1.1 \\
\hline Mining and quarrying $1 /$ & 24 & 2.9 & 6.7 & 15.0 & 3.3 & 3.3 & -1.1 \\
\hline Utilities & 22 & 1.5 & 4.2 & 1.0 & 2.3 & 5.3 & 0.4 \\
\hline Construction & 72 & -4.4 & -0.8 & 3.8 & -0.6 & 1.3 & 2.3 \\
\hline Transportation and communications & 84 & 1.9 & 3.6 & 8.0 & 6.6 & 4.8 & 6.9 \\
\hline Distributive trades & 143 & -0.9 & 5.0 & 4.0 & 1.7 & 3.1 & 3.8 \\
\hline Other services & 404 & -0.8 & 2.0 & 3.6 & 2.9 & 3.4 & 3.9 \\
\hline GDP 2/ & 1,000 & 0.1 & 2.5 & 4.5 & 2.8 & 2.8 & 3.2 \\
\hline \multicolumn{8}{|l|}{ Memorandum Items: } \\
\hline Extrac tion of oil and gas & 17 & 7.2 & 13.4 & 24.0 & 5.8 & 4.9 & 0.8 \\
\hline Non-oil GDP & 983 & -0.7 & 2.0 & 4.0 & 2.7 & 2.4 & 3.1 \\
\hline Durable goods & & -0.1 & 1.4 & 8.1 & 2.0 & 4.8 & 1.6 \\
\hline Non-durable goods & & 1.9 & 1.1 & 3.4 & 0.5 & 0.5 & 0.7 \\
\hline Intermediate goods & & 0.8 & 2.9 & 6.1 & 2.1 & 0.5 & 0.7 \\
\hline Investment goods & & -2.3 & 1.6 & 5.2 & 1.8 & 2.5 & 0.9 \\
\hline
\end{tabular}

Source: Office for National Statistics, Economic Trends.

1/ Includes oil and gas extraction.

2/ Based on output data. 
Table A2. United Kingdom: Labor Market Indicators

(In thousands)

\begin{tabular}{|c|c|c|c|c|c|c|}
\hline Level at March & 1993 & 1994 & 1995 & 1996 & 1997 & 1998 \\
\hline \multicolumn{7}{|l|}{ Work force in employment= } \\
\hline $\begin{array}{l}(1+2+3+4) \\
\text { (Percent change) }\end{array}$ & $\frac{25.599}{(-2.2)}$ & $\frac{25.759}{(0.6)}$ & $\frac{26.025}{(1.0)}$ & $\frac{26.605}{(2.2)}$ & $\frac{27.061}{(1.7)}$ & $\frac{27,568}{(1.9)}$ \\
\hline 1. Employees in employment & 21,557 & 21,654 & 21,921 & 22,577 & 23,059 & 23,651 \\
\hline Male & 10,968 & 10,941 & 11,077 & 11,336 & 11,681 & 12,004 \\
\hline Female & 10,589 & 10,713 & 10,844 & 11,241 & 11,378 & 11,647 \\
\hline 2. Self-employed $1 / 2 /$ & 3,386 & 3,520 & 3,594 & 3,581 & 3,606 & 3,539 \\
\hline 3. H.M. forces $1 /$ & 275 & 254 & 233 & 225 & 214 & 211 \\
\hline $\begin{array}{l}\text { 4. Work related government } \\
\text { training programs } 1 /\end{array}$ & 354 & 323 & 270 & 214 & 175 & 153 \\
\hline Unemployment & $\underline{2.954}$ & $\underline{2.756}$ & $\underline{2.378}$ & $\underline{2.214}$ & $\underline{1.763}$ & $\underline{1,383}$ \\
\hline Employees in employment 3 / & 100.0 & 100.0 & 100.0 & 100.0 & 100.0 & 100.0 \\
\hline Manufactures & 18.7 & 18.5 & 18.8 & 18.6 & 18.2 & 17.8 \\
\hline Services & 76.7 & 77.3 & 77.5 & 76.3 & 76.7 & 76.4 \\
\hline Other & 4.6 & 4.2 & 3.7 & 5.1 & 5.0 & 5.8 \\
\hline
\end{tabular}

Source: Department of Employment, Employment Gazette.

$1 /$ Not adjusted for seasonal variation.

2/Estimates of the self-employed, with or without employees, are based on labor force surveys for data through 1990 , and on Department of Employment estimates thereafter.

3/ Great Britain, percent of total. 
Table A3. United Kingdom: Selected National Accounts Aggregates at 1990 Market Prices

\begin{tabular}{|c|c|c|c|c|c|c|c|c|c|}
\hline & 1993 & 1994 & 1995 & 1996 & 1997 & $\begin{array}{l}1997 \\
\text { 1st } \\
\text { half }\end{array}$ & $\begin{array}{l}7 \text { 1/ } \\
\text { 2nd } \\
\text { half }\end{array}$ & $\begin{array}{l}1998 \\
\text { 1st } \\
\text { qtr. }\end{array}$ & $\begin{array}{l}\text { 1/ } \\
\text { 2nd } \\
\text { qtr. }\end{array}$ \\
\hline & \multicolumn{9}{|c|}{ (In billions of pounds sterling) } \\
\hline Private consumption & 420.1 & 431.5 & 438.5 & 454.7 & 472.9 & 468.6 & 477.2 & 482.4 & 484.9 \\
\hline Government consumption & 136.4 & 138.3 & 140.4 & 142.8 & 142.9 & 142.6 & 143.1 & 144.8 & 145.4 \\
\hline Gross domestic fixed capital formation & 109.1 & 113.0 & 116.4 & 122.0 & 130.1 & 127.0 & 133.3 & 138.8 & 138.8 \\
\hline Residential & 21.5 & 22.3 & 21.6 & 22.2 & 23.0 & 22.5 & 23.6 & 24.1 & 24.2 \\
\hline Non-residential construction & 36.3 & 37.0 & 35.3 & 34.8 & 36.2 & 35.1 & 37.2 & 39.3 & 38.1 \\
\hline Plant and equipment & 47.5 & 50.1 & 55.5 & 60.9 & 66.7 & 64.9 & 68.5 & 71.7 & 72.7 \\
\hline Stockbuilding and work in progress & 0.4 & 4.8 & 4.5 & 1.8 & 3.1 & 2.5 & 3.7 & 2.0 & 3.5 \\
\hline Total domestic demand & 679.9 & 702.9 & 715.4 & 737.1 & 764.8 & 756.4 & 773.2 & 784.5 & 788.7 \\
\hline Exports of goods and services & 169.2 & 184.9 & 202.4 & 217.6 & 236.5 & 232.1 & 240.9 & 239.9 & 244.2 \\
\hline Imports of goods and services & 184.6 & 194.6 & 205.2 & 224.0 & 245.1 & 238.9 & 251.4 & 256.6 & 261.6 \\
\hline Foreign Balance & -15.9 & -9.7 & -2.8 & $-6,4$ & -8.6 & -6.8 & -10.4 & -16.6 & -17.6 \\
\hline \multicolumn{10}{|l|}{ Gross domestic product: } \\
\hline Expenditure estimate & 664.0 & 693.2 & 712.5 & 730.8 & 756.2 & 749.6 & 762.8 & 767.9 & 771.0 \\
\hline Statistical adjustment & -- & -- & -- & -- & -0.1 & -0.5 & 0.3 & 2.3 & 3.0 \\
\hline Average estimate $2 /$ & 664.0 & 693.2 & 712.5 & 730.8 & 756.1 & 749.1 & 763.2 & 770.2 & 774.0 \\
\hline & \multicolumn{9}{|c|}{ (Annual percentage change) } \\
\hline Private consumption & 2.5 & 2.7 & 1.6 & 3.7 & 4.0 & 3.8 & 4.2 & 3.7 & 2.8 \\
\hline Government consumption & -0.8 & 1.4 & 1.6 & 1.7 & 0.0 & 0.1 & -0.0 & 1.3 & 2.2 \\
\hline Gross domestic fixed capital formation & 0.8 & 3.6 & 2.9 & 4.9 & 6.6 & 4.8 & 8.4 & 11.2 & 7.5 \\
\hline Residential & 7.2 & 3.6 & -3.0 & 2.6 & 3.9 & 5.1 & 2.9 & 7.6 & 7.3 \\
\hline Non-residential construction & -1.1 & 2.1 & -4.7 & -1.4 & 3.9 & -0.3 & 8.1 & 14.4 & 6.3 \\
\hline Plant and equipment & 0.6 & 5.4 & 10.8 & 9.7 & 9.5 & 7.6 & 11.4 & 12.7 & 9.9 \\
\hline Stockbuilding and work in progress $3 /$ & 0.4 & 0.7 & -0.0 & -0.4 & 0.2 & -0.1 & 0.5 & 0.0 & 0.0 \\
\hline Total domestic demand & 2.1 & 3.4 & 1.8 & 3.0 & 3.8 & 3.1 & 4.5 & 4.5 & 3.4 \\
\hline Exports of goods and services & 3.9 & 9.2 & 9.5 & 7.5 & 8.7 & 8.9 & 8.5 & 5.0 & 3.5 \\
\hline Imports of goods and services & 3.2 & 5.4 & 5.5 & 9.1 & 9.5 & 8.4 & 10.4 & 10.1 & 6.9 \\
\hline Foreign balance $3 /$ & 0.1 & 0.9 & 1.0 & -0.5 & -0.3 & 0.0 & -0.7 & -1.6 & -1.1 \\
\hline \multicolumn{10}{|l|}{ Gross domestic product: } \\
\hline Expenditure estimate & 2.3 & 4.4 & 2.8 & 2.6 & 3.5 & 3.1 & 3.8 & 3.0 & 2.3 \\
\hline Average estimate $2 /$ & 2.3 & 4.4 & 2.8 & 2.6 & 3.5 & 3.1 & 3.9 & 3.4 & 2.8 \\
\hline \multicolumn{10}{|l|}{$\begin{array}{l}\text { Memorandum items: } \\
\text { GDP at factor cost based on: }\end{array}$} \\
\hline Expenditure data & 2.5 & 4.5 & 2.8 & 2.8 & 3.2 & 2.8 & 3.7 & 2.7 & 2.3 \\
\hline Income data & 2.2 & 4.5 & 2.8 & 2.5 & 2.9 & 2.8 & 3.0 & 2.9 & $\ldots$ \\
\hline Output data & 2.5 & 4.5 & 2.8 & 2.8 & 3.2 & 2.7 & 3.7 & 3.2 & 2.8 \\
\hline Non-oil GDP & 2.0 & 4.0 & 2.7 & 2.4 & 3.1 & 3.1 & 3.2 & 3.0 & 2.4 \\
\hline GDP at current market prices $4 /$ & 638 & 676 & 713 & 755 & 801 & 788 & 815 & 825 & 835 \\
\hline (Percent change) & $(5.1)$ & $(6,0)$ & $(5.4)$ & $(5.9)$ & $(6.2)$ & $(5.7)$ & $(6,7)$ & $(5.5)$ & $(5.2)$ \\
\hline
\end{tabular}

Sources: Office for National Statistics, Economic Trends.

1/ Half yearly and quarterly levels at seasonally adjusted annual rates or changes from a year ago.

2/ An unweighted average of expenditure, income, and output estimates.

$3 /$ Contribution to growth of GDP (average estimate).

4/ Average measure in billions of pounds. 


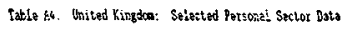

(It percent of (AP)

\begin{tabular}{llllllllllllll}
\hline 1985 & 1995 & 1987 & 1988 & 1989 & 1990 & 1991 & 1992 & 1993 & 1996 & 1995 & 1996 & 1997 \\
\hline
\end{tabular}

\begin{tabular}{|c|c|c|c|c|c|c|c|c|c|c|c|c|c|}
\hline Jisposable inccose & 68.7 & 69.4 & 68.4 & 68.6 & 68.7 & 66.3 & 69.7 & 71.8 & 32.0 & 70.6 & 70.9 & 70,9 & 71.0 \\
\hline Consurention & 59.8 & 61.8 & 63.7 & 62.5 & 32.5 & 62.6 & 63.2 & 68.9 & 64,3 & 64.2 & 63,7 & 64.3 & 64.5 \\
\hline Saving & 10.4 & 9.3 & 8.4 & 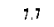 & 8.0 & 2.6 & 8.3 & 0.6 & 8.4 & 8.6 & 9,4 & 8.9 & 8.8 \\
\hline (satings ratio) & (15.1) & (19.6) & (12.2) & (11.2) & (11.7) & (11.1) & (12.6) & $(13.4)$ & (23.1) & (12.1) & (13.2) & $\{12.5\}$ & $(22.4)$ \\
\hline Viet capital terens:ars & 0.1 & -0.8 & -0.1 & -0.3 & -0.1 & 0.0 & 0.3 & 0,3 & 0.5 & 0.5 & 0.2 & 0.1 & 0.2 \\
\hline Investnent & 4.6 & 5.0 & 5.6 & 6.8 & 6.1 & $\$ .2$ & 4.3 & 3.9 & 4.1 & 4.2 &., 2 & 4.3 & 4.5 \\
\hline of which: Druellings & (2.) $)$ & (3.0) & (3.2) & $(3.9)$ & (3.7) & (3.1) & $(2,7)$ & $(2,7)$ & (2.7) & (2.1) & (2.7) & (2.) & $(2.8\}$ \\
\hline Firtanciai balance & 2.8 & 0.9 & -0.7 & -2.8 & $\cdot 1.5$ & 0.4 & 3.0 & 5.0 & .6 & 3.5 & 4.3 & 3.9 & 3.5 \\
\hline Finantizal assats & 182.2 & 203,6 & 203.2 & 200.3 & 227.8 & 214.2 & 229.6 & 244.9 & 278.8 & 256.9 & 276.9 & 282.5 & 317.8 \\
\hline Finanche? Wabilities & 57.8 & 62.9 & 67,8 & 39.3 & 77.1 & 80.3 & 81.5 & 80.8 & 79.3 & 78,3 & $m$ & 78.7 & 78.6 \\
\hline Net Eirancsal assots & 124,8 & 240.9 & 137,7 & 234.6 & 150.7 & 139.9 & 148,1 & 164.2 & 199.5 & 178.9 & 99.2 & 203.8 & 239.0 \\
\hline $\begin{array}{l}\text { Iangibile assets } \\
\text { of which: }\end{array}$ & 183.9 & 197.2 & 216.5 & 259.5 & 255.9 & 232.6 & 219.8 & 199.3 & 194,4 & 233.9 & 17.8 & 271.5 & $\ldots 1$ \\
\hline Ressidential buildings & $\{157.4\}$ & $(071,4)$ & (192.4) & $(233.9)$ & $(229.3)$ & $\{209.0\}$ & $(193,6)$ & $(179,9)$ & $(127,0)$ & $1664.1)$ & $(198,6)$ & [152.8] & (...) $n$ \\
\hline Ret wealth & 338.8 & 358,6 & 337.2 & 428.6 & 439,3 & 398.6 & 398.7 & 391.7 & 423.9 & 385.9 & 391.3 & 395,8 & \\
\hline
\end{tabular}

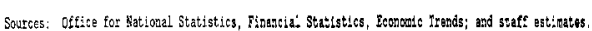

i/ Ho Lergar salcilated by Central Stazistles offlce. 
Table A5. United Kingdom: Components of Personal Income

\begin{tabular}{|c|c|c|c|c|c|c|c|c|c|}
\hline & 1993 & 1994 & 1995 & 1996 & 1997 & $\begin{array}{l}199 \\
\text { 1st } \\
\text { half }\end{array}$ & $\begin{array}{l}1 / \\
\text { 2nd } \\
\text { half }\end{array}$ & $\begin{array}{l}1998 \\
\text { 1st } \\
\text { qtr. }\end{array}$ & $\begin{array}{l}\text { 2/ } \\
\text { qta. }\end{array}$ \\
\hline & \multicolumn{9}{|c|}{ (In billions of pounds $s$} \\
\hline Total personal income & 573.0 & 598.9 & 636.1 & 670.0 & 711.4 & 702.5 & 720.4 & 737.2 & $\ldots$ \\
\hline Wages, salaries, and armed forces pay & 308.0 & 318.7 & 333.6 & 349.7 & 374.1 & 368.2 & 380.1 & 391.3 & $\ldots$ \\
\hline Employers' contributions & 43.6 & 46.3 & 47.7 & 51.1 & 52.9 & 52.4 & 53.4 & 54.7 & $\cdots$ \\
\hline \multicolumn{10}{|l|}{ National Insurance benefits and other } \\
\hline current grants from Government & 88.5 & 92.6 & 96.2 & 99.6 & 101.6 & 100.9 & 102.3 & 101.8 & $\ldots$ \\
\hline Other personal income & 132.9 & 141.2 & 158.7 & 169.6 & 182.8 & 181.0 & 184.5 & 189.4 & $\ldots$ \\
\hline U.K. taxes on income & 63.6 & 68.3 & 74.3 & 75.7 & 79.4 & 78.0 & 80.7 & 92.9 & $\ldots$ \\
\hline National Insurance contributions & 39.3 & 42.1 & 44.4 & 46.6 & 49.6 & 48.8 & 50.5 & 51.5 & $\ldots$ \\
\hline Community charge & 8.0 & 8.4 & 9.2 & 9.9 & 10.7 & 10.5 & 10.9 & 10.9 & $\ldots$ \\
\hline Other miscellaneous deductions & 2.8 & 2.9 & 2.9 & 2.9 & 3.0 & 3.0 & 3.0 & 2.8 & $\cdots$ \\
\hline Total personal disposable Income & 459.2 & 477.2 & 505.4 & 535.0 & 568.7 & 562.3 & 575.2 & 579.1 & $\ldots$ \\
\hline Real personal disposable income $2 /$ & 393.3 & 399.6 & 412.4 & 425.8 & 443.4 & 441.1 & 445.6 & 446.0 & $\ldots$ \\
\hline Consumer expenditure & 399.1 & 419.3 & 438.5 & 467.8 & 498.3 & 490.4 & 506.2 & 514.2 & 519.7 \\
\hline Real consumer expenditure & 420.1 & 431.5 & 438.5 & 454.7 & 472.9 & 468.6 & 477.2 & 482.4 & 484,9 \\
\hline Durable goods & 36.2 & 38.6 & 39.5 & 42.7 & 46.8 & 44.8 & 48.8 & 49.9 & 49.3 \\
\hline Non-durable goods & 187.1 & 192.2 & 194.1 & 202.3 & 208.2 & 207.8 & 208.7 & 208.2 & 210.2 \\
\hline Services & 196.8 & 200.7 & 204.8 & 209.6 & 217.8 & 216.0 & 219.7 & 224.4 & 225,4 \\
\hline Personal savings ratio $3 /$ & 13.1 & 12.1 & 13.2 & 12.5 & 12.4 & 12.7 & 12.0 & 11.2 & $\ldots$ \\
\hline \multirow[t]{2}{*}{ Personal financial balance $3 /$} & 6.5 & 4.9 & 6.1 & 5.6 & 4.9 & 5.5 & 4.4 & 1.9 & $\ldots$ \\
\hline & \multicolumn{9}{|c|}{ (Annual percentage change) } \\
\hline Total personal income & 4.5 & 4.5 & 6.2 & 5.3 & 6.2 & 6.0 & 6.3 & 7.0 & $\ldots$ \\
\hline Wages, salaries and armed forces pay & 2.2 & 3.5 & 4.7 & 4.9 & 7.0 & 6.7 & 7.3 & 6.9 & $\cdots$ \\
\hline Employers' contributions & 5,9 & 6.3 & 2.9 & 7.2 & 3.6 & 3.4 & 3.7 & 4.7 & $\cdots$ \\
\hline National Insurance benefits etc. & 10.6 & 4.6 & 3.8 & 3.6 & 2.0 & 2.5 & 1.5 & 1.3 & $\cdots$ \\
\hline Other personal income & 5.8 & 6.3 & 12.4 & 6.8 & 7.8 & 7.6 & 8.0 & 11.3 & $\cdots$ \\
\hline U.K. taxes on income & -2.4 & 7.3 & 8.8 & 1.9 & 4.8 & 3.2 & 6.4 & 18.6 & .. \\
\hline National Insurance contributions & 6.2 & 7.2 & 5.4 & 5.0 & 6.6 & 6.2 & 7.0 & 6.6 & $\ldots$ \\
\hline Community charge $4 /$ & -0.0 & -0.1 & -0.1 & -0.1 & -0.2 & -0.2 & -0.2 & -0.2 & . . \\
\hline Total personal disposable income & 5.4 & 3.9 & 5.9 & 5.9 & 6.3 & 6.4 & 6.2 & 5.5 & $\ldots$ \\
\hline Real personal disposable income & 1.9 & 1.6 & 3.2 & 3.3 & 4.1 & 4.2 & 4.0 & 3.4 & .. \\
\hline Consumer expenditure & 5.8 & 5.0 & 4.6 & 6.7 & 6.5 & 6.4 & 6.6 & 5.7 & 5.1 \\
\hline Real consumer expenditure & 2.5 & 2.7 & 1.6 & 3.7 & 4.0 & 3.8 & 4.2 & 3.7 & 2.8 \\
\hline Durable goods & 5.1 & 6.5 & 2.4 & 8.1 & 9.6 & 6.1 & 13.0 & 15.8 & 6.0 \\
\hline Non-durable goods & 1.7 & 2.7 & 1.0 & 4.2 & 2.9 & 3.7 & 2.2 & 0.4 & 1.0 \\
\hline Services & 2.8 & 2.0 & 2.0 & 2.4 & 3.9 & 3.5 & 4.3 & 4.4 & 3.9 \\
\hline Memorandum item: & & & & & & & & & \\
\hline Implied consumption deflator & 3.3 & 2.3 & 2.9 & 2.9 & 2.4 & 2.5 & 2.4 & 2.0 & 2.3 \\
\hline
\end{tabular}

Source: Office for National Statistics, United Kingdom National Accounts.

1/ Half yearly and quarterly levels at seasonally adjusted annual rates or changes from a year ago.

2/ In 1990 prices, deflated by the implied deflator for consumers' expenditure.

3/ Relative to personal disposable income.

4/ Contribution to growth in disposable income. 
tab10 A6. United Kingdom: Selected Finencial Stasiaties

Industrial and Comnarcial Companies

(In pescent of GDP)

\begin{tabular}{|c|c|c|c|c|c|c|c|c|c|c|c|c|c|}
\hline & 1985 & 1986 & 1987 & 1988 & 1989 & 1990 & 2991 & 1992 & 1993 & 1994 & 2995 & 1996 & 1997 \\
\hline $\begin{array}{l}\text { Incone } \\
\text { of which: gross }\end{array}$ & 21.8 & 19.3 & 21.1 & 21.9 & 23.3 & 21.8 & 19.6 & 18.9 & 19.5 & 21.3 & 22.2 & 22.8 & 22.4 \\
\hline $\begin{array}{l}\text { trading profies } 1 / \\
\text { Less: taxes, intereste, }\end{array}$ & $(16.2)$ & $(14,2)$ & $(24.9)$ & $(14,9)$ & $(14.7)$ & $(13.7)$ & $(18,9)$ & $(12.5)$ & (13.2) & (14.4) & $(14,6)$ & $(15.7)$ & (15.2) \\
\hline $\begin{array}{l}\text { and dividunds } \\
\text { Undistributed tineome }\end{array}$ & 21.8 & 10.0 & 20.6 & 11.8 & 14.7 & 14,5 & 12.8 & 11.9 & 10.7 & 11.2 & 13.0 & 13.6 & 14.3 \\
\hline (=saving) & 10.0 & 9.2 & 10.5 & 10.1 & 8.7 & 7.3 & 6.8 & 7.0 & 8.8 & 10.2 & 9.2 & 9.2 & 8. 1 \\
\hline Less: investment & 8.8 & 8.5 & 20.1 & 11.4 & 12.1 & 10.7 & 8.1 & 7.8 & 7.9 & 8.0 & 8.8 & 8.6 & 8.6 \\
\hline $\begin{array}{l}\text { Einancial balance } \\
\text { Einanced by: }\end{array}$ & 1.3 & 0.3 & 0.4 & -1.3 & -3.4 & -3.4 & -1.3 & -0.8 & 0.9 & 2.2 & 0.3 & 0.6 & $\cdot 0.5$ \\
\hline $\begin{array}{l}\text { Net borrowing } 27 \\
\text { Other }\end{array}$ & $\begin{array}{r}1.6 \\
-2.8\end{array}$ & $\begin{array}{l}-0.2 \\
-0.6\end{array}$ & $\begin{array}{r}20 \\
-2.6\end{array}$ & $\begin{array}{r}7.0 \\
-5.8\end{array}$ & $\begin{array}{r}6.8 \\
-3.4\end{array}$ & $\begin{array}{r}4.3 \\
-1.0\end{array}$ & $\begin{array}{l}0.1 \\
1.2\end{array}$ & $\begin{array}{r}-0.2 \\
1.0\end{array}$ & $\begin{array}{r}-2.1 \\
1.2\end{array}$ & $\begin{array}{l}-1.3 \\
-0.9\end{array}$ & $\begin{array}{r}1.6 \\
.1 .9\end{array}$ & $\begin{array}{r}1.3 \\
-1.9\end{array}$ & $\begin{array}{l}0.0 \\
0.5\end{array}$ \\
\hline $\begin{array}{l}\text { Financial assets } \\
\text { Financial liabilities }\end{array}$ & $\begin{array}{r}67.8 \\
129.4\end{array}$ & $\begin{array}{r}72.3 \\
150.2\end{array}$ & $\begin{array}{r}69.4 \\
155.0\end{array}$ & $\begin{array}{r}70.4 \\
160.2\end{array}$ & $\begin{array}{r}72.6 \\
184.2\end{array}$ & $\begin{array}{r}62.2 \\
169.8\end{array}$ & $\begin{array}{r}61.7 \\
191.5\end{array}$ & $\begin{array}{r}62.2 \\
190.5\end{array}$ & $\begin{array}{r}63.7 \\
209.1\end{array}$ & $\begin{array}{r}62.2 \\
190.1\end{array}$ & $\begin{array}{r}65.0 \\
204.1\end{array}$ & $\begin{array}{r}64.2 \\
208.4\end{array}$ & $\begin{array}{r}65.8 \\
226.9\end{array}$ \\
\hline Net financial assets & -61.6 & $-77,9$ & -85.6 & -89.8 & -111.6 & -106.5 & $\begin{array}{l}-119.8 \\
\text { (In pero }\end{array}$ & -128.3 & -145.4 & -127.9 & -139.1 & -144.3 & -161.2 \\
\hline $\begin{array}{l}\text { Merororandum items: } \\
\text { Liquidity ratio 3/ } \\
\text { Income goaring af }\end{array}$ & 20.8 & 29.9 & 17.6 & 18.9 & 25.8 & $\begin{array}{l}52.5 \\
28.9\end{array}$ & $\begin{array}{l}52.2 \\
27.8\end{array}$ & $\begin{array}{l}52.0 \\
24.8\end{array}$ & $\begin{array}{l}56.8 \\
17.6\end{array}$ & $\begin{array}{l}67.5 \\
15.1\end{array}$ & $\begin{array}{l}66.5 \\
15 ?\end{array}$ & $\begin{array}{l}66.2 \\
14.9\end{array}$ & 67.8 \\
\hline
\end{tabular}

$1 /$ Net of stock appreciation.

1/ Rank borrowing and other loans less benk deposits.

3/ Laree companies. 
Table A7. United Kingdom: Selected Indicators of Investment Activity

\begin{tabular}{|c|c|c|c|c|c|c|c|c|c|}
\hline & \multirow[t]{2}{*}{1993} & \multirow[t]{2}{*}{1994} & \multirow[t]{2}{*}{1995} & \multirow[t]{2}{*}{1996} & \multirow[t]{2}{*}{1997} & \multicolumn{2}{|c|}{$19971 /$} & \multicolumn{2}{|c|}{$19981 /$} \\
\hline & & & & & & $\begin{array}{l}\text { 1st } \\
\text { half }\end{array}$ & $\begin{array}{l}\text { 2nd } \\
\text { half }\end{array}$ & $\begin{array}{l}\text { 1st } \\
\text { qtr. }\end{array}$ & $\begin{array}{l}\text { 2nd } \\
\text { qtr. }\end{array}$ \\
\hline & \multicolumn{9}{|c|}{ (In billions of 1990 pounds sterling) } \\
\hline Gross domestic fixed capital formation & 109.1 & 113.0 & 116.4 & 122.0 & 130.1 & 126.7 & 132.3 & 138.2 & 136.2 \\
\hline \multicolumn{10}{|l|}{ By sector: } \\
\hline Private sector & 77.3 & 81.2 & 84.1 & 89,8 & 96.6 & 95.5 & 97.7 & 101.1 & $\ldots$ \\
\hline Residential & 18.4 & 19.1 & 18.8 & 19.9 & 21.1 & 20.7 & 21.9 & 22.1 & 21.9 \\
\hline Nonresidential & 58.9 & 62.1 & 65.3 & 69.9 & 75.5 & 75.0 & 76.1 & 78.8 & $\ldots$ \\
\hline Public sector & 31.9 & 31.8 & 32.3 & 32.3 & 33.5 & 31.2 & 34.6 & 37.1 & 36.6 \\
\hline General government & 15.0 & 15.3 & 14.0 & 10.9 & 9.9 & 9.7 & 10.1 & 9.2 & 8.6 \\
\hline Public corporations & 5.3 & 5.1 & 4.8 & 4.3 & 3.9 & 4.0 & 3.8 & 5.6 & $\cdots$ \\
\hline \multicolumn{10}{|l|}{ By industry: } \\
\hline Manufacturing & 11.2 & 12.0 & 13.2 & 12.4 & 14.2 & 14.2 & 14.3 & 14.2 & $\ldots$ \\
\hline \multicolumn{10}{|l|}{ Mineral oil and natural gas } \\
\hline \multirow[t]{2}{*}{ extraction } & 5.3 & 4.0 & 4.3 & 4.2 & 4.3 & 4.3 & 4.3 & 6.4 & $\cdots$ \\
\hline & \multicolumn{5}{|c|}{ (Growth $\mathrm{r}$} & \multicolumn{3}{|c|}{ in percent per annum) } & \\
\hline Gross domestic fixed capital formation & 0.8 & 3.6 & 2.9 & 4.9 & 6.6 & 4.6 & 7.6 & 11.0 & 5.7 \\
\hline \multicolumn{10}{|l|}{ By sector: } \\
\hline Private sector & 0.1 & 5.1 & 3.6 & 6.8 & 7.6 & 9.4 & 5.9 & 9.4 & $\cdots$ \\
\hline Residential & 6.0 & 3.9 & -1.5 & 6.0 & 5.9 & 8.6 & 5.6 & 8.3 & 4.4 \\
\hline Nonresidential & -1.7 & 5.4 & 5.1 & 7.0 & 8.1 & 9.8 & 6.4 & 9.6 & $\ldots$ \\
\hline Public sector & 2.7 & -0.1 & 1.4 & -0.1 & 3.9 & -7.8 & 12.5 & 15.6 & 21.0 \\
\hline Genera1 government & 4.2 & 1.4 & -8.2 & -22.2 & -9.0 & -21.7 & 7.8 & -18.1 & 5.5 \\
\hline Public corporations & 6.2 & -2.4 & -6.9 & -10.0 & -10.5 & -13.5 & -7.1 & 35.7 & $\cdots$ \\
\hline \multicolumn{10}{|l|}{ By industry: } \\
\hline Manufacturing & -5.1 & 6.8 & 9.9 & -5.6 & 14.4 & 12.0 & 16.9 & 7.2 & $\ldots$ \\
\hline \multicolumn{10}{|l|}{ Mineral oil and natural gas } \\
\hline \multirow[t]{2}{*}{ extraction } & -12.5 & -24.6 & 8.0 & -1.4 & 0.2 & 0.0 & 0.3 & 51.5 & $\cdots$ \\
\hline & \multicolumn{5}{|c|}{ (In percent of GDP (average estimate), } & \multicolumn{4}{|c|}{ calculated in nominal terms) } \\
\hline Gross domestic fixed capital formation & 15.9 & 15.9 & 16.3 & 16.7 & 16.8 & 16.5 & 16.8 & 17.2 & 16.8 \\
\hline \multicolumn{10}{|l|}{ By sector: } \\
\hline Private sector & 12.7 & 12.9 & 13.7 & 14.6 & 15.0 & 14.8 & 15.2 & 15.5 & $\ldots$ \\
\hline Residential & 2.7 & 2.7 & 2.7 & 2.7 & 2.8 & 2.7 & 2.9 & $\ldots$ & $\ldots$ \\
\hline Nonresidential & 10.1 & 10.2 & 10.9 & 12.0 & 12.3 & 12.1 & 12.4 & $\ldots$ & $\ldots$ \\
\hline Public sector & 3.1 & 3.0 & 2.7 & 2.0 & 1.7 & 1.7 & 1.7 & 1.8 & $\cdots$ \\
\hline General government & 2.4 & 2.3 & 2.0 & 1.4 & 1.2 & 1.2 & 1.2 & 1.1 & 1.0 \\
\hline Public corporations & 0.8 & 0.7 & 0.7 & 0.6 & 0.5 & 0.5 & 0.5 & 0.7 & $\ldots$ \\
\hline \multicolumn{10}{|l|}{ By industry: } \\
\hline Manufacturing & 1.9 & 2.0 & 2.2 & 2.0 & 2.2 & 2.2 & 2.1 & $\ldots$ & $\ldots$ \\
\hline \multicolumn{10}{|l|}{ Mineral oil and natural gas } \\
\hline extraction & 0.7 & 0.5 & 0.6 & 0.6 & 0.5 & 0.5 & 0.5 & $\ldots$ & $\ldots$ \\
\hline
\end{tabular}

Source: Office for National Statistics, United Kingdom National Accounts.

1/ Half yearly and quarterly levels at seasonally adjusted annual rates or changes from a year ago. 
Table A8. United Kingdom: Selected Indicators of Wage Developments $1 /$

(Percentage changes from previous year)

\begin{tabular}{|c|c|c|c|c|c|c|c|c|c|}
\hline & \multirow[t]{2}{*}{1993} & \multirow[t]{2}{*}{1994} & \multirow[t]{2}{*}{1995} & \multirow[t]{2}{*}{1996} & \multirow[t]{2}{*}{1997} & \multicolumn{2}{|c|}{$19972 /$} & \multicolumn{2}{|c|}{$19982 /$} \\
\hline & & & & & & $\begin{array}{l}1 s t \\
\text { half }\end{array}$ & $\begin{array}{l}\text { 2nd } \\
\text { half }\end{array}$ & $\begin{array}{l}\text { lst } \\
\text { qtr. }\end{array}$ & $\begin{array}{l}\text { 2nd } \\
\text { qtr. }\end{array}$ \\
\hline \multicolumn{10}{|l|}{ Average earnings } \\
\hline Whole economy & 3.6 & 3.8 & 3.4 & 3.9 & 4.4 & 4.4 & 4.4 & 5.0 & 5.0 \\
\hline Manufacturing & 4.6 & 4.7 & 4.5 & 4.4 & 4.4 & 4.4 & 4.4 & 5.4 & 5.1 \\
\hline Services & 3.1 & 3.5 & 2.8 & 3.7 & 4.5 & 4.5 & 4.5 & 5.1 & 5.3 \\
\hline \multicolumn{10}{|c|}{$\begin{array}{l}\text { Average earnings deflated by } \\
\text { retall prices }\end{array}$} \\
\hline Whole economy & 2.0 & 1.3 & 0.0 & 1.4 & 1.2 & 1.6 & 0.8 & 1.5 & 1.0 \\
\hline Services & 1.5 & 1.0 & -0.6 & 1.2 & 1.3 & 1.7 & 0.9 & 1.6 & 1.2 \\
\hline \multicolumn{10}{|c|}{$\begin{array}{l}\text { Average earnings deflated by } \\
\text { producers' output prices }\end{array}$} \\
\hline Whole economy & -0.3 & 1.3 & -0.6 & 1.2 & 3.4 & 3.3 & 3.5 & 4.4 & 4.0 \\
\hline Manufacturing & 0.6 & 2.2 & 0.4 & 1.7 & 3.4 & 3.4 & 3.5 & 4.8 & 4.1 \\
\hline \multicolumn{10}{|c|}{ Unit wage costs $3 /$} \\
\hline Whole economy & -0.2 & 0.2 & 1.7 & 2.0 & 3.3 & 3.2 & 3.3 & 3.1 & 2.9 \\
\hline Manufacturing & -0.4 & -0.0 & 3.8 & 5.4 & 3.3 & 3.2 & 3.3 & 5.9 & 5.1 \\
\hline
\end{tabular}

Sources: Office for National Statistics, Economic Trends; and Department of Employment, Employment Gazette.

1) Great Britain.

2/ Relative to the same period in the previous year.

3/ Wages and salaries per unit of output, based on seasonally adjusted monthly statistios for earnings, employment and output. 
Table A9. United Kingdom: Selected Indicators of Price Developments

(Percentage change from corresponding period of previous year)

\begin{tabular}{|c|c|c|c|c|c|c|c|c|c|}
\hline & \multirow[t]{2}{*}{1993} & \multirow[t]{2}{*}{1994} & \multirow[t]{2}{*}{1995} & \multirow[t]{2}{*}{1996} & \multirow[t]{2}{*}{1997} & \multicolumn{2}{|c|}{1997} & \multicolumn{2}{|c|}{1998} \\
\hline & & & & & & $\begin{array}{l}\text { 1st. } \\
\text { hal.f }\end{array}$ & $\begin{array}{l}\text { 2nd } \\
\text { half }\end{array}$ & $\begin{array}{l}\text { lst } \\
\text { qtr. }\end{array}$ & $\begin{array}{l}\text { 2nd } \\
\text { qtr. }\end{array}$ \\
\hline \multicolumn{10}{|l|}{ GDP deflator 1/ } \\
\hline (market prices) & 2.8 & 1.5 & 2.5 & 3.3 & 2.6 & 2.5 & 2.7 & 2.1 & 2.3 \\
\hline (factor cost) & 2.8 & 1.3 & 2.1 & 3.1 & 2.4 & 2.5 & 2.2 & 2.5 & 2.6 \\
\hline \multicolumn{10}{|l|}{ Retail prices } \\
\hline A11 items & 1.6 & 2.5 & 3.4 & 2.4 & 3.1 & 2.7 & 3.6 & 3.4 & 4.0 \\
\hline Non-food items & 1.5 & 2.7 & 3.3 & 2.3 & 3.6 & 3.2 & 4.0 & 3.8 & 4.4 \\
\hline Housing & -5.4 & 3.3 & 6.7 & 1.4 & 6.5 & 4.3 & 8.6 & 8.8 & 10.4 \\
\hline \multicolumn{10}{|l|}{ Excluding mortgage } \\
\hline interest (RPIX) & 3.0 & 2.4 & 2.8 & 2.9 & 2.8 & 2.7 & 2.8 & 2.5 & 3.0 \\
\hline \multicolumn{10}{|l|}{ Producer prices } \\
\hline Input & 4.6 & 1.9 & 8.8 & -1.2 & -8.3 & -8.2 & -8.3 & -9.7 & -7.9 \\
\hline Output & 4.0 & 2.5 & 4.0 & 2.6 & 0.9 & 1.0 & 0.9 & 0.6 & 1.0 \\
\hline
\end{tabular}

Source: Office for National Statistics, Economic Trends.

1/ Based on expenditure estimate. 
Table A10. United Kingdom: Selected Balance of Payments Indicators (In billions of pounds sterling)

\begin{tabular}{|c|c|c|c|c|c|c|}
\hline & 1993 & 1994 & 1995 & 1996 & 1997 & $\begin{array}{l}\text { Est. } \\
1998\end{array}$ \\
\hline $\begin{array}{l}\text { Gurrent account balance } \\
\text { Visible balance } \\
\text { Exports } \\
\text { Imports }\end{array}$ & $\begin{array}{l}-10.3 \\
-13.5 \\
121.4 \\
134.9\end{array}$ & $\begin{array}{r}-1.7 \\
-11.1 \\
134.7 \\
145.8\end{array}$ & $\begin{array}{r}-3.7 \\
-11.6 \\
153.1 \\
164.7\end{array}$ & $\begin{array}{r}-1.8 \\
-12.7 \\
166.9 \\
179.6\end{array}$ & $\begin{array}{r}4.5 \\
-13.0 \\
170.1 \\
183.1\end{array}$ & $\begin{array}{r}-3.0 \\
-19.0 \\
163.8 \\
182.8\end{array}$ \\
\hline $\begin{array}{l}\text { Invisible trade balance } \\
\text { Services balance } \\
\text { Interest, profits and } \\
\text { dividends balance } \\
\text { Transfers balance }\end{array}$ & $\begin{array}{r}2.6 \\
-4.9\end{array}$ & $\begin{array}{r}9.7 \\
-5.0\end{array}$ & $\begin{array}{r}7.9 \\
-6.9\end{array}$ & $\begin{array}{r}10.8 \\
7.0\end{array}$ & $\begin{array}{l}12.1 \\
-4.0\end{array}$ & $\begin{array}{l}16.0 \\
11.2\end{array}$ \\
\hline $\begin{array}{l}\text { Net long-term capital flows } \\
\text { Net direct investment } \\
\text { Net portfolio investment }\end{array}$ & $\begin{array}{r}-46.0 \\
-7.4 \\
-38.6\end{array}$ & $\begin{array}{r}35.5 \\
-15.9 \\
51.4\end{array}$ & $\begin{array}{l}-32.3 \\
-13.6 \\
-18.7\end{array}$ & $\begin{array}{r}-35.3 \\
-5.1 \\
-30.2\end{array}$ & $\begin{array}{l}-33.3 \\
-13.0 \\
-20.3\end{array}$ & $\begin{array}{r}-45.71 / \\
2.41 / \\
-48.21 /\end{array}$ \\
\hline Basic balance & -56.3 & 33.8 & -35.9 & -37.1 & -28.8 & $-49.21 /$ \\
\hline Net short-term capital flows & 57.9 & -38.9 & 33.9 & 34.7 & 24.7 & $34.81 /$ \\
\hline Statistical discrepancy & -1.5 & 5.0 & 2.0 & 2.4 & 4.2 & $1.11 /$ \\
\hline $\begin{array}{l}\text { Memorandum Items: } \\
\text { Non-oil trade balance } \\
\text { (As percent of GDP) } \\
\text { Gurrent account balance } \\
\text { (as percent of GDP) }\end{array}$ & $\begin{array}{r}-15.9 \\
-2.5\end{array}$ & $\begin{array}{r}-15.0 \\
-2.2\end{array}$ & $\begin{array}{r}-15.9 \\
-2.2\end{array}$ & $\begin{array}{r}-17.5 \\
-2.3\end{array}$ & $\begin{array}{r}-17.6 \\
-2.2\end{array}$ & $\begin{array}{r}-21.7 \\
-2.6\end{array}$ \\
\hline
\end{tabular}

Source: Office for National Statistics.

1/ First quarter at an annual rate. 
Table A11. United Kingdom: Merchandise Trade Indicators

(Percentage change from a year ago)

\begin{tabular}{|c|c|c|c|c|c|c|c|c|c|}
\hline & \multirow[b]{2}{*}{1993} & \multirow[b]{2}{*}{1994} & \multirow[b]{2}{*}{1995} & \multirow[b]{2}{*}{1996} & \multirow[b]{2}{*}{1997} & \multicolumn{2}{|c|}{1997} & \multicolumn{2}{|c|}{1998} \\
\hline & & & & & & $\begin{array}{l}\text { 1st } \\
\text { half }\end{array}$ & $\begin{array}{l}\text { 2nd } \\
\text { half }\end{array}$ & $\begin{array}{l}\text { 1st } \\
\text { qtr. }\end{array}$ & $\begin{array}{l}\text { 2nd } \\
\text { qtr. }\end{array}$ \\
\hline \multicolumn{10}{|l|}{ Exports } \\
\hline \multicolumn{10}{|l|}{ Value } \\
\hline All goods & 13.1 & 10.9 & 13.7 & 9.0 & 1.9 & 2.1 & 1.8 & -3.7 & -4.1 \\
\hline Non-oil goods & 12.7 & 11.2 & 14.4 & 8.6 & 2.5 & 2.2 & 2.9 & -1.8 & -3.0 \\
\hline \multicolumn{10}{|l|}{ Volume } \\
\hline Al1 goods & 3.6 & 10.3 & 7.8 & 7.1 & 8.0 & 7.6 & 8.3 & 2.5 & 0.1 \\
\hline Non-oil goods & 2.6 & 9.8 & 8.6 & 7.9 & 8.6 & 8.2 & 9.1 & 3.1 & 0.1 \\
\hline \multicolumn{10}{|l|}{ Price } \\
\hline A11 goods & 9.2 & 0.6 & 5.4 & 1.8 & -5.6 & -5.1 & -6.0 & -6.1 & -4.2 \\
\hline Non-oil goods & 9.8 & 1.3 & 5.3 & 0.6 & -5.6 & -5.5 & -5.7 & -4.7 & -3.0 \\
\hline \multicolumn{10}{|l|}{ Imports } \\
\hline \multicolumn{10}{|l|}{ Value } \\
\hline All goods & 12.0 & 8.1 & 12.9 & 9.1 & 2.0 & 0.8 & 3.1 & 0.8 & -0.4 \\
\hline Non-oil goods & 12.1 & 9.2 & 13.4 & 8.7 & 2.3 & 1.0 & 3.6 & 1.3 & 0.3 \\
\hline \multicolumn{10}{|l|}{ Volume } \\
\hline All goods & 3.8 & 4.4 & 4.5 & 8.9 & 8.9 & 7.7 & 10.2 & 6.8 & 3.4 \\
\hline Non-oil goods & 3.6 & 5.4 & 5.1 & 9.3 & 9.1 & 7.9 & 10.3 & 6.5 & 3.6 \\
\hline \multicolumn{10}{|l|}{ Prices } \\
\hline All goods & 7.8 & 3.6 & 8.1 & 0.2 & -6.4 & -6.3 & -6.4 & -5.6 & -3.7 \\
\hline Non-oil goods & 8.2 & 3.6 & 8.0 & -0.5 & -6.2 & -6.4 & -6.0 & -4.8 & -3.1 \\
\hline \multicolumn{10}{|l|}{ Terms of trade } \\
\hline All goods & 1.2 & -2.9 & -2.4 & 1.6 & 0.9 & 1.6 & -0.0 & -0.5 & -0.5 \\
\hline Non-oil goods & 1.4 & -2.2 & -2.4 & 1.1 & 0.6 & 1.5 & 0.2 & 0.1 & 0.1 \\
\hline
\end{tabular}

Source: Office for National Statistics, Monthly Digest of Statistics. 
Table A12. United Kingdom: Exports by Commodity--Volume Indices

(Indices: 1990-100; seasonally adjusted)

\begin{tabular}{|c|c|c|c|c|c|c|c|c|c|}
\hline & \multirow[t]{2}{*}{1993} & \multirow[t]{2}{*}{1994} & \multirow[t]{2}{*}{1995} & \multirow[t]{2}{*}{1996} & \multirow[t]{2}{*}{1997} & \multicolumn{2}{|c|}{1997} & \multicolumn{2}{|c|}{1998} \\
\hline & & & & & & $\begin{array}{l}\text { lst } \\
\text { half }\end{array}$ & $\begin{array}{l}\text { 2nd } \\
\text { haif }\end{array}$ & $\begin{array}{l}\mathrm{st} \\
\mathrm{gtt} .\end{array}$ & $\begin{array}{l}\text { 2nd } \\
\text { quts. }\end{array}$ \\
\hline Total & 107.4 & 118.5 & 127.7 & 136.8 & 147.7 & 145.3 & 150.1 & 146.4 & 148.0 \\
\hline Food, beverages and tobecco & 114.1 & 129.0 & 140.7 & 140.3 & 145.3 & 146.5 & 144.3 & 146.7 & 141.7 \\
\hline Basic Materials & 97.6 & 107.5 & $1: 4.8$ & 110.8 & 119.2 & 115.7 & 122.8 & 119,0 & 115.0 \\
\hline Fuets & 122.1 & 140.8 & 142.9 & 139.0 & 1423 & 141.0 & 143.8 & 136.7 & 137.7 \\
\hline Total Manufactures & 106.8 & 117.3 & 127.3 & 138.8 & 151.3 & 248.3 & 154.0 & 150.0 & 153.0 \\
\hline \multicolumn{10}{|l|}{ Manufacturers excluding erratics if } \\
\hline Total less SNAPS & 104.2 & 88.5 & 99.9 & 109.6 & 1177 & 116.2 & 119.3 & 1199 & 118.6 \\
\hline Total less PS & 112.2 & 92.2 & 100.0 & 103.9 & 107.5 & 107.2 & 107.8 & 109.3 & 105.7 \\
\hline Chemicals & 118.5 & 94.8 & 100.0 & 105.2 & 110.8 & 110.0 & 111.5 & 113.3 & 1100 \\
\hline Other less PS & 106.1 & 89.3 & 100.1 & 102.2 & 104.2 & 104.3 & 104.2 & 105.0 & 101.3 \\
\hline \multicolumn{10}{|l|}{ Finished manufactures $3 /$} \\
\hline Total less SNA & 103.3 & 86.8 & 100.0 & 112.6 & 122.8 & 120.5 & 125.0 & 125.7 & 1250 \\
\hline Passenger cars & 110.9 & 81.3 & 99.9 & 121.6 & 126.8 & 127.2 & 126.3 & 120.3 & 133.3 \\
\hline Other Consumer & 91.9 & 93.1 & 99.8 & 112.6 & 119.4 & 119.2 & 120.0 & 116.1 & 113.5 \\
\hline Intermediate & 100.8 & 89.1 & 100.2 & 110.1 & 120.2 & 117.2 & 122.8 & 123.9 & 120.5 \\
\hline Capital & 102.9 & 82.7 & 100.1 & 113.2 & 126.7 & 123.5 & 129.7 & 134.4 & 134.1 \\
\hline
\end{tabular}

Source: Office for National Statistics, Monthly Digest of Statistios

$1 /$ These are defined as ships, North Sea installations, aircraft, precious stones and silver

2/ Exchuding precious stones and silver. 
Table A13. United Kingdon: Imports by Commodity-- Tolume Indices

(1990=100; seasonally adjusted)

\begin{tabular}{|c|c|c|c|c|c|c|c|c|c|}
\hline & \multirow[t]{2}{*}{1993} & \multirow[t]{2}{*}{1994} & \multirow[t]{2}{*}{1995} & \multirow[t]{2}{*}{1996} & \multirow[t]{2}{*}{1997} & \multicolumn{2}{|c|}{1997} & \multicolumn{2}{|c|}{1998} \\
\hline & & & & & & $\begin{array}{l}\text { lst } \\
\text { half }\end{array}$ & $\begin{array}{l}\text { 2nd } \\
\text { half }\end{array}$ & $\begin{array}{l}\text { lst } \\
\text { qter. }\end{array}$ & $\begin{array}{l}\text { 2nd } \\
\text { qtr. }\end{array}$ \\
\hline $\begin{array}{l}\text { Total } \\
\text { Food beverazes }\end{array}$ & 104,8 & 109.4 & 114.3 & 124,5 & 135.6 & 132.7 & 138.5 & 137.9 & 140.9 \\
\hline $\begin{array}{l}\text { Pood, beverages } \\
\text { and tobacco }\end{array}$ & 111,9 & 112.8 & 123.4 & 126.2 & 116.7 & 118.5 & 114.8 & 112.7 & 109.7 \\
\hline Basic materials & 96.6 & 107.8 & 114.7 & 110.5 & 105.7 & 107.2 & 104.1 & 99.9 & 99.3 \\
\hline Fuels & 90.4 & 86.3 & 94.6 & 109.1 & 97.6 & 100.5 & 94.7 & 79.9 & 74.5 \\
\hline Total marufactures & 106.2 & 113.1 & 118.5 & 129.6 & 142.6 & 139.1 & 146.2 & 144.5 & 147.9 \\
\hline \multicolumn{10}{|l|}{$\begin{array}{l}\text { lianufacturers excluding } \\
\text { erratics }\end{array}$} \\
\hline \multicolumn{10}{|l|}{ Seni-nanufactures $2 /$} \\
\hline Total Less PS & 105.9 & 94.5 & 100.0 & 107.2 & 111.7 & 109.8 & 113.5 & 115.0 & 114.3 \\
\hline Chenicals & $115 . j$ & 92.0 & 100.1 & 108.8 & 114.4 & 211.5 & 117.4 & 118.5 & 117.9 \\
\hline Other less PS & 100.6 & 96.3 & 100.1 & 105.8 & 109.7 & 108.5 & 110.8 & 112.3 & 111.7 \\
\hline \multicolumn{10}{|c|}{ Finished manufactures $3 /$} \\
\hline Total less SitA & 103.1 & 92.0 & 100.1 & 112.3 & 124,8 & 120.8 & 128.8 & 133.3 & 129.3 \\
\hline Passenger cars & 85.8 & 100.3 & 99.8 & 112,4 & 139.5 & 134.6 & 144.4 & 143.1 & 136.8 \\
\hline Other consumer & 113.2 & 101.0 & 100.2 & 108.5 & 120.0 & 116.5 & 123.5 & 129.9 & 126.5 \\
\hline Intermediate & 97.1 & 88.8 & 100.0 & 116.7 & 121.3 & 117.6 & 125.1 & 128.6 & 125.2 \\
\hline Gapita: & 110.0 & 85.7 & 99.9 & 109.7 & 127.1 & 122.4 & 131.9 & 138.2 & 133.9 \\
\hline
\end{tabular}

Source: Office for National Statistics, Monthly Digest of Statistics.

1/ These are defined as ships, North Sea Installations, aircraft, precious stones and silver. 2/ Excluding precious stones and silver.

3/ Excluding ships, North Sea installations and aircraft. 
Table A14. United Kingdom: Direction of Trade

(Balance of payments basis)

\begin{tabular}{|c|c|c|c|c|c|c|}
\hline & 1993 & 1994 & 1995 & 1996 & 1997 & 1998 \\
\hline Fyonorts $f$ & \multicolumn{6}{|c|}{ (In percent of total) } \\
\hline $\begin{array}{l}\text { European Union } \\
\text { Rest of Western Europe } \\
\text { North America } \\
\text { Other OECD } \\
\text { Oil exporting countries } \\
\text { Other countries } 2 /\end{array}$ & $\begin{array}{r}56.9 \\
4.3 \\
14.5 \\
5.4 \\
5.4 \\
13.5\end{array}$ & $\begin{array}{r}57.2 \\
4.3 \\
14.6 \\
5.8 \\
4.3 \\
13.8\end{array}$ & $\begin{array}{r}58.6 \\
4.2 \\
13.4 \\
6.1 \\
4.1 \\
13.6\end{array}$ & $\begin{array}{r}57.5 \\
4.4 \\
13.4 \\
6.6 \\
4.8 \\
13.4\end{array}$ & $\begin{array}{r}56.4 \\
4.6 \\
14.0 \\
6.3 \\
5.5 \\
13.1\end{array}$ & $\begin{array}{r}58.1 \\
4.8 \\
14.7 \\
5.5 \\
4.8 \\
12.1\end{array}$ \\
\hline Total & 100.0 & 100.0 & 100.0 & 100.0 & 100.0 & 100.0 \\
\hline \multicolumn{7}{|l|}{ Imports, c.i.f. } \\
\hline $\begin{array}{l}\text { European Union } \\
\text { Rest of Western Europe } \\
\text { North America } \\
\text { Other OECD } \\
\text { Oil exporting countries } \\
\text { Other countries 2/ }\end{array}$ & $\begin{array}{r}55.1 \\
7.0 \\
13.2 \\
8.4 \\
2.7 \\
13.6\end{array}$ & $\begin{array}{r}56.6 \\
6.4 \\
13.3 \\
8.4 \\
2.1 \\
13.2\end{array}$ & $\begin{array}{r}57.0 \\
6.3 \\
13.5 \\
8.3 \\
1.8 \\
13.1\end{array}$ & $\begin{array}{r}55.8 \\
6.3 \\
13.9 \\
7.6 \\
1.8 \\
14.5\end{array}$ & $\begin{array}{r}54.6 \\
5.9 \\
14.8 \\
7.9 \\
1.8 \\
15.0\end{array}$ & $\begin{array}{r}54.4 \\
5.7 \\
15.1 \\
8.2 \\
1.8 \\
14.8\end{array}$ \\
\hline Total & 100.0 & 100.0 & 100.0 & 100.0 & 100.0 & 100.0 \\
\hline $\begin{array}{l}\text { Memorandum items: } \\
\text { Total exports, f.o.b. } \\
\text { Total imports, c.i.f. }\end{array}$ & $\begin{array}{l}121.4 \\
134.9\end{array}$ & $\begin{array}{l}134.7 \\
145.8\end{array}$ & $\begin{array}{l}153.1 \\
164.7\end{array}$ & $\begin{array}{l}166.9 \\
179.6\end{array}$ & $\begin{array}{l}170.1 \\
183.1\end{array}$ & $\begin{array}{l}162.4 \\
181.1\end{array}$ \\
\hline
\end{tabular}

Source: Office for National Statistics.

1) First two quarters at a seasonally adjusted annual rate.

2) Including residuals. 
Table A15. United Kingdom: Nonfactor Services

(In billions of pounds sterling; seasonally adjusted)

\begin{tabular}{|c|c|c|c|c|c|c|c|c|}
\hline & \multirow[t]{2}{*}{1993} & \multirow[t]{2}{*}{1994} & \multirow[t]{2}{*}{1995} & \multirow[t]{2}{*}{1996} & \multirow[t]{2}{*}{1997} & \multicolumn{2}{|c|}{$19971 /$} & \multirow{2}{*}{$\begin{array}{c}1998 \\
1 \text { st } \\
\text { qtr. }\end{array}$} \\
\hline & & & & & & $\begin{array}{l}\text { lst } \\
\text { half }\end{array}$ & $\begin{array}{l}\text { 2nd } \\
\text { half }\end{array}$ & \\
\hline \multicolumn{9}{|l|}{ Credits } \\
\hline \multicolumn{9}{|l|}{$\begin{array}{l}\text { Private sector and public } \\
\text { corporations }\end{array}$} \\
\hline Sea transport & 3.9 & 4.2 & 4.6 & 4.7 & 4.5 & 4.5 & 4.4 & 4.3 \\
\hline Civil aviation & 5.1 & 5.4 & 5.8 & 6.3 & 6.2 & 6.3 & 6.1 & 6.4 \\
\hline Travel & 9.5 & 9.9 & 12.1 & 12.4 & 12.6 & 12.7 & 12.6 & 12.5 \\
\hline Financial and other services & 20.0 & 21.8 & 23.6 & $26.4^{\prime}$ & 29.6 & 29.3 & 30.0 & 29.0 \\
\hline Total & 38.5 & 41.4 & 46.1 & 49.7 & 52.9 & 52.8 & 53.1 & 52.1 \\
\hline General government & 0.5 & 0.5 & 0.5 & 0.4 & 0.4 & 0.3 & 0.4 & 0.4 \\
\hline Total credits & 39.1 & 41.9 & 46.6 & 50.2 & 53.3 & 53.1 & 53.5 & 52.5 \\
\hline \multicolumn{9}{|l|}{ Debits } \\
\hline \multicolumn{9}{|l|}{$\begin{array}{l}\text { Private sector and public } \\
\text { corporations }\end{array}$} \\
\hline Sea transport & 4.2 & 4.5 & 4.7 & 5.2 & 5.2 & 5.1 & 5.2 & 5.0 \\
\hline Civil aviation & 5.4 & 6.1 & 6.3 & 7.0 & 7.7 & 7.5 & 7.9 & 8.2 \\
\hline Travel & 13.0 & 14.5 & 15.7 & 16.3 & 17.2 & 17.0 & 17.5 & 19.4 \\
\hline Financial and other services & 8.6 & 9.5 & 10.6 & 11.9 & 11.8 & 11.6 & 11.9 & 11.8 \\
\hline Total & 31.2 & 34.6 & 37.2 & 40.4 & 41.9 & 41.2 & 42.5 & 44.4 \\
\hline General government & 2.3 & 2.5 & 2.5 & 2.8 & 2.1 & 2.3 & 1.9 & 1.6 \\
\hline Total debits & 33.5 & 37.2 & 39.7 & 43.2 & 44.0 & 43.5 & 44.5 & 46.0 \\
\hline \multicolumn{9}{|l|}{ Balance } \\
\hline \multicolumn{9}{|l|}{$\begin{array}{l}\text { Private sector and public } \\
\text { corporations }\end{array}$} \\
\hline Sea transport & -0.3 & -0.3 & -0.1 & -0.5 & .0 .7 & -0.6 & -0.8 & -0.7 \\
\hline Civil aviation & -0.3 & -0.7 & -0.5 & -0.7 & -1.5 & -1.2 & -1.8 & -1.9 \\
\hline Travel & -3.5 & -4.6 & -3.6 & -3.9 & -4.6 & -4.3 & -4.9 & -6.8 \\
\hline Financial and other services & 11.4 & 12.3 & 13.0 & 14.5 & 17.8 & 17.6 & 18.0 & 17.1 \\
\hline Total & 7.3 & 6.8 & 8.9 & 9.3 & 11.0 & 11.6 & 10.5 & 7.7 \\
\hline General government & -1.8 & -2.0 & -2.0 & -2.4 & -1.8 & -2.0 & -1.5 & -1.2 \\
\hline Total & 5.5 & 4.8 & 6.9 & 7.0 & 9.3 & 9.6 & 9.0 & 6.5 \\
\hline
\end{tabular}

Source: Office for National Statistics, Balance of Payments

1/ At an annual rate. 
Table A16. United Kingdom: Capital Account 1/

(In billions of pounds sterling)

\begin{tabular}{|c|c|c|c|c|c|c|}
\hline & 1993 & 1994 & 1995 & 1996 & 1997 & 1998 \\
\hline \multicolumn{7}{|c|}{ Transactions in external assets of the U.K. } \\
\hline Direct investment & -17.7 & -22.0 & -27.9 & -21.8 & -35.6 & -27.0 \\
\hline Portfolio investment & -84.1 & 18.4 & -38.1 & -59.7 & -42.5 & -51.2 \\
\hline Ordinary shares & -8.1 & -0.6 & -8.2 & -9.2 & $\ldots$ & $\ldots$ \\
\hline Bonds & -76.1 & 19.1 & -29.9 & -50.5 & $\ldots$ & $\ldots$ \\
\hline Bank lending & 3.2 & -48.2 & -26.9 & -63.5 & -160.2 & -128.8 \\
\hline Non-bank lending & -57.2 & 18.5 & -25.5 & -68.7 & -22.7 & -21.9 \\
\hline Official reserves & -0.7 & -1.0 & 0.2 & 0.5 & 2.4 & 5.0 \\
\hline \multicolumn{7}{|l|}{ Other assets of } \\
\hline central government & -0.6 & -0.6 & -0.6 & -0.7 & -0.6 & -0.7 \\
\hline Total & -157.2 & -34.9 & -118.8 & -214.0 & -259.2 & -224.5 \\
\hline \multicolumn{7}{|c|}{ Transactions in external liabilities of the U.K. } \\
\hline Direct investment & 10.3 & 6.1 & 14.3 & 16.7 & 22.6 & 29.4 \\
\hline \multicolumn{7}{|l|}{ Of which: } \\
\hline Non-oil companies & 8.5 & 3.4 & 14.4 & 13.5 & 20.3 & 28.5 \\
\hline Portfolio investment & 45.5 & 32.9 & 19.5 & 29.6 & 22.2 & 3.0 \\
\hline \multicolumn{7}{|c|}{ Of which: U.K. company securities } \\
\hline Bonds & 11.8 & 22.3 & 16.7 & 17.5 & 16.3 & 1.3 \\
\hline Ordinary shares & 17.4 & 4.9 & 3.7 & 4.4 & 2.2 & -3.0 \\
\hline Bank borrowing & 23.1 & 47.4 & 36.5 & 75.2 & 154.7 & 246.3 \\
\hline Non-bank borrowing & 93.0 & -55.4 & 48.5 & 92.8 & 53.1 & 39.4 \\
\hline \multicolumn{7}{|l|}{ Other liabilities of } \\
\hline general government & -2.9 & 0.5 & 1.7 & -0.9 & -2.1 & -4.4 \\
\hline Total & 169.1 & 31.5 & 120.5 & 213.4 & 250.5 & 213.6 \\
\hline \multicolumn{7}{|l|}{ Net transactions } \\
\hline Total & 11.8 & -3.4 & 1.7 & -0.6 & -8.6 & -10.9 \\
\hline \multicolumn{7}{|l|}{ Of which: } \\
\hline Long-term private capital & -46.0 & 35.5 & -32.3 & -35.3 & -33.3 & -45.7 \\
\hline Short-term private capital & 62.0 & -37.7 & 32.6 & 35.7 & 25.0 & 35.1 \\
\hline \multicolumn{7}{|l|}{ Memorandum items: } \\
\hline Net foreign assets $3 /$ & 37.3 & 28.0 & 25.9 & 23.7 & 8.5 & 17.1 \\
\hline Official reserves $3 /$ & 29.0 & 28.1 & 31.8 & 27.3 & 22.8 & 21.3 \\
\hline Change in official reserves & -1.5 & 1.0 & -3.7 & 4.4 & 4.5 & 4.3 \\
\hline
\end{tabular}

Source: Office for National Statistics, Balance of Payments.

1/ A negative sign indicates a net outflow of capital (i.e. an increase in assets or a reduction

in liabilities).

2/ First quarter at an annual rate.

3/ End-period. 
Table A17, United Kingdom: General Government Accounts

(National accounts basis)

$1992 / 93 \quad 1993 / 94 \quad 1994 / 95 \quad 1995 / 96 \quad 1996 / 97 \quad 1997 / 98$

\begin{tabular}{|c|c|c|c|c|c|c|}
\hline \multirow[b]{2}{*}{ Current receipts } & \multirow[b]{2}{*}{$\underline{219.6}$} & \multicolumn{4}{|c|}{ (In billions of pounds sterling) } & \multirow[b]{2}{*}{$\underline{307.9}$} \\
\hline & & $\underline{228.0}$ & $\underline{248.5}$ & $\underline{267.7}$ & $\underline{281.8}$ & \\
\hline Taxes on income & 72.3 & 73.8 & 83.8 & 92.2 & 98.1 & 110.7 \\
\hline \multicolumn{6}{|l|}{ Social security } & 119.7 \\
\hline contributions & 37.0 & 40.4 & 42.9 & 45.0 & 47.1 & 50.4 \\
\hline Other & 22.4 & 22.7 & 23.8 & 25.3 & 26.4 & 27.1 \\
\hline Capital receipts & 2.6 & $\underline{2.4}$ & $\underline{2.9}$ & $\underline{3.1}$ & $\underline{3.9}$ & $\underline{4.6}$ \\
\hline Total receipts & $\underline{222.1}$ & $\underline{230.4}$ & $\underline{251.4}$ & $\underline{270.7}$ & $\underline{285.7}$ & $\underline{312.5}$ \\
\hline Current expenditure & $\underline{246.0}$ & $\underline{260.7}$ & $\underline{273.7}$ & $\underline{288.0}$ & $\underline{298.0}$ & $\underline{303.2}$ \\
\hline Einal consumption & 133.4 & 139.1 & 145.4 & 151,3 & 156.4 & 159.2 \\
\hline Subsidies and grants & 98.6 & 109.8 & 113.9 & 120.4 & 124.4 & 126.2 \\
\hline Debt interest & 17.8 & 19.7 & 22.7 & 25.7 & 27.0 & 28.8 \\
\hline Capital expenditure & $\underline{21.4}$ & 19.6 & 20.0 & $\underline{19.2}$ & 16.4 & 14.6 \\
\hline Unallocated reserve & $\ldots$ & $\cdots$ & $\cdots$ & $\ldots$ & $\ldots$ & $\ldots$ \\
\hline Total expenditure 1/ & $\underline{267.3}$ & $\underline{280.3}$ & $\underline{293.7}$ & $\underline{307.3}$ & 314.4 & $\underline{317.7}$ \\
\hline Financial balance $1 /$ & -45.2 & -50.0 & -42.3 & -36.5 & -28.7 & -5.2 \\
\hline Financial transactions $2 /$ & 45.2 & $\underline{50.0}$ & 42. 3 & $\underline{36.5}$ & $\underline{28.7}$ & $\underline{5.2}$ \\
\hline Net lending & $\overline{6.9}$ & $\overline{3.7}$ & $\overline{5.4}$ & $\overline{2.4}$ & $\overline{5.3}$ & 2.1 \\
\hline \multicolumn{7}{|l|}{ of which: } \\
\hline Privatization proceeds & $(8.2)$ & $(5.4)$ & $(6.4)$ & $(2.4)$ & $(4.4)$ & $(1,8)$ \\
\hline Other miscellaneous $3 /$ & 0.5 & -0.6 & -0.9 & 0.2 & 0.7 & 1.5 \\
\hline Borrowing requirement & 37.8 & 46.8 & 37.8 & 33.9 & 22.7 & 1.6 \\
\hline \multicolumn{7}{|c|}{ (Annual percentage changes) } \\
\hline \multicolumn{7}{|l|}{ Memorandum 1tems: } \\
\hline Total receipts & -1.5 & 3.7 & 9.1 & 7.7 & 5.5 & 9.4 \\
\hline Total expenditure & 9.5 & 4.9 & 4.8 & 4.6 & 2.3 & 1.1 \\
\hline Including net lending & 10.2 & 6.2 & 4.2 & 5.8 & 1.4 & 2.1 \\
\hline \multicolumn{7}{|c|}{ (In percent of GDP) $4 /$} \\
\hline Total receipts & 36.3 & 35.6 & 36.7 & 37.5 & 37.4 & 38.5 \\
\hline Total expenditure & 43.6 & 43.3 & 42.8 & 42.5 & 41.1 & 39.1 \\
\hline Including net lending & 42.5 & 42.7 & 42.0 & 42.2 & 40.4 & 38.9 \\
\hline Financial balance & -7.4 & -7.7 & -6.2 & -5.1 & -3.8 & -0.6 \\
\hline $\begin{array}{l}\text { Borrowing requirement } \\
\text { Excluding privatization }\end{array}$ & 6.2 & 7.2 & 5.5 & 4.7 & 3.0 & 0.2 \\
\hline receipts & 7.5 & 8.1 & 6.4 & 5.0 & 3.5 & 0.4 \\
\hline
\end{tabular}

Sources: Office for National Statistics, Financial Statistics and Economic Trends; and

H.M. Treasury, Financial Statement and Budget Report, 1996/97, 1997/98, and July 1997.

1/ Including unallocated reserve where appropriate.

2/ A positive sign denotes a drawdown in assets or an increase in liabilities.

3/ Including accruals adjustments and balancing 1 tem.

4/ GDP adjusted for statistical distortions arising from the introduction of the community charge. 1996/97 figures use budget estimate of GDP. 
Table A18. United Kingdom: Nominal Exchange Rates 1/

(Period average)

\begin{tabular}{|c|c|c|c|c|c|}
\hline & $\begin{array}{c}\text { Nominal Effective } \\
\text { Exchange Rate } \\
(1990=100)\end{array}$ & $\begin{array}{l}\text { U.S. } \\
\text { Doilar }\end{array}$ & $\begin{array}{l}\text { Deutsche } \\
\text { Mark }\end{array}$ & $\begin{array}{l}\text { Japanese } \\
\text { Yen }\end{array}$ & $\begin{array}{c}\text { French } \\
\text { Franc }\end{array}$ \\
\hline $\begin{array}{l}1993 \\
1994 \\
1995 \\
1996 \\
1997 \\
1998\end{array}$ & $\begin{array}{r}88.98 \\
89.25 \\
84.88 \\
86.34 \\
100.58 \\
103.94\end{array}$ & $\begin{array}{l}1.5020 \\
1.5316 \\
1.5785 \\
1.5617 \\
1.6377 \\
1.6564\end{array}$ & $\begin{array}{l}2.4827 \\
2.4825 \\
2.2617 \\
2.3507 \\
2.8395 \\
2.9139\end{array}$ & $\begin{array}{l}166.99 \\
156.41 \\
148.36 \\
170.00 \\
198.16 \\
216.75\end{array}$ & $\begin{array}{l}8.5037 \\
8.4940 \\
7.8781 \\
7.9906 \\
9.5575 \\
9.7692\end{array}$ \\
\hline $\begin{array}{l}1997 \\
\text { January } \\
\text { February } \\
\text { March } \\
\text { April } \\
\text { May } \\
\text { June } \\
\text { July } \\
\text { August } \\
\text { September } \\
\text { October } \\
\text { November } \\
\text { December }\end{array}$ & $\begin{array}{r}96.05 \\
97.51 \\
97.38 \\
99.46 \\
99.10 \\
100.42 \\
104.61 \\
102.67 \\
100.39 \\
101.09 \\
103.79 \\
104.43\end{array}$ & $\begin{array}{l}1.6602 \\
1.6258 \\
1.6053 \\
1.6289 \\
1.6333 \\
1.6440 \\
1.6713 \\
1.6034 \\
1.5996 \\
1.6312 \\
1.6877 \\
1.6615\end{array}$ & $\begin{array}{l}2.6635 \\
2.7227 \\
2.7240 \\
2.7870 \\
2.7819 \\
2.8397 \\
2.9948 \\
2.9540 \\
2.8642 \\
2.8655 \\
2.9250 \\
2.9519\end{array}$ & $\begin{array}{l}195.94 \\
199.99 \\
196.88 \\
204.45 \\
194.35 \\
187.75 \\
192.46 \\
189.04 \\
193.15 \\
197.48 \\
211.43 \\
214.97\end{array}$ & $\begin{array}{r}8.9934 \\
9.1937 \\
9.1817 \\
9.3868 \\
9.3800 \\
9.5828 \\
10.1005 \\
9.9488 \\
9.6215 \\
9.6124 \\
9.8028 \\
9.8862\end{array}$ \\
\hline $\begin{array}{l}1998 \\
\text { January } \\
\text { February } \\
\text { March } \\
\text { April } \\
\text { May } \\
\text { June } \\
\text { July } \\
\text { August } \\
\text { September } \\
\text { October } \\
\text { November } \\
\text { December }\end{array}$ & $\begin{array}{l}104.70 \\
104.75 \\
106.75 \\
107.17 \\
103.52 \\
105.44 \\
105.37 \\
104.56 \\
103.36 \\
100.68 \\
100.59 \\
100.47\end{array}$ & $\begin{array}{l}1.6353 \\
1.6394 \\
1.6610 \\
1.6719 \\
1.6376 \\
1.6498 \\
1.6435 \\
1.6313 \\
1.6803 \\
1.6946 \\
1.6616 \\
1.6704\end{array}$ & $\begin{array}{l}2.9709 \\
2.9741 \\
3.0342 \\
3.0341 \\
2.9061 \\
2.9560 \\
2.9549 \\
2.9177 \\
2.8615 \\
2.7754 \\
2.7942 \\
2.7873\end{array}$ & $\begin{array}{l}211.70 \\
206.56 \\
213.76 \\
220.14 \\
221.07 \\
231.91 \\
231.30 \\
235.97 \\
226.16 \\
205.55 \\
200.36 \\
196.48\end{array}$ & $\begin{array}{r}9.9488 \\
9.9744 \\
10.1692 \\
10.1711 \\
9.7469 \\
9.9171 \\
9.8986 \\
9.7796 \\
9.5891 \\
9.3117 \\
9.3686 \\
9.3547\end{array}$ \\
\hline
\end{tabular}

Source: International Monetary Fund, International Financial Statistics.

1/ Units of foreign currency per pound sterling. 
Table A19. United Kingdom: Interest Rates 1/

(In percent per annum)

\begin{tabular}{|c|c|c|c|c|c|c|c|}
\hline & & \multicolumn{2}{|c|}{ Three-Month Rates } & \multirow{2}{*}{$\begin{array}{c}\text { London } \\
\text { Clearing } \\
\text { Banks' } \\
\text { Base Rate }\end{array}$} & \multicolumn{3}{|c|}{$\begin{array}{c}\text { Government Securities } \\
\text { Galculated Redemption } \\
\text { Yields }\end{array}$} \\
\hline & & $\begin{array}{l}\text { Inter- } \\
\text { bank }\end{array}$ & $\begin{array}{c}\text { Treasury } \\
\text { Bills }\end{array}$ & & $\begin{array}{c}\text { 5-year } \\
\text { maturity }\end{array}$ & $\begin{array}{l}10-\text { year } \\
\text { maturity }\end{array}$ & $\begin{array}{l}20 \text {-year } \\
\text { maturity }\end{array}$ \\
\hline $\begin{array}{l}1993 \\
1994 \\
1995 \\
1996 \\
1997\end{array}$ & & $\begin{array}{l}5.87 \\
5.50 \\
6.68 \\
6.02 \\
6.88\end{array}$ & $\begin{array}{l}3.02 \\
4.27 \\
5.51 \\
5.03 \\
5.07\end{array}$ & $\begin{array}{l}5.50 \\
6.25 \\
6.50 \\
6.00 \\
7.25\end{array}$ & $\begin{array}{l}6.65 \\
7.83 \\
7.93 \\
7.28 \\
6.98\end{array}$ & $\begin{array}{l}7.47 \\
8.17 \\
8.23 \\
7.79 \\
7.02\end{array}$ & $\begin{array}{l}7.87 \\
8.05 \\
8.26 \\
8.10 \\
7.09\end{array}$ \\
\hline 1998 & $\begin{array}{l}\text { 1st qtr. } \\
\text { 2nd qtr. } \\
\text { 3rd qtr. } \\
4 \text { th qtr. }\end{array}$ & $\begin{array}{l}7.55 \\
7.57 \\
7.67 \\
6.90\end{array}$ & $\begin{array}{l}5.08 \\
5.01 \\
4.88 \\
4.31\end{array}$ & $\begin{array}{l}7.25 \\
7.50 \\
7.50 \\
6.25\end{array}$ & $\begin{array}{l}6.24 \\
6.06 \\
5.87 \\
4.89\end{array}$ & $\begin{array}{l}6.02 \\
5.81 \\
5.50 \\
4.77\end{array}$ & $\begin{array}{l}5.98 \\
5.66 \\
5.36 \\
4.79\end{array}$ \\
\hline 1997 & $\begin{array}{l}\text { January } \\
\text { February } \\
\text { March } \\
\text { April } \\
\text { May } \\
\text { June } \\
\text { July } \\
\text { August } \\
\text { September } \\
\text { October } \\
\text { November } \\
\text { December }\end{array}$ & $\begin{array}{l}6.32 \\
6.19 \\
6.20 \\
6.38 \\
6.45 \\
6.75 \\
7.04 \\
7.24 \\
7.29 \\
7.35 \\
7.62 \\
7.70\end{array}$ & $\begin{array}{l}5.05 \\
5.00 \\
5.14 \\
5.17 \\
5.13 \\
4.92 \\
5.07 \\
5.13 \\
4.97 \\
4.95 \\
5.15 \\
5.16\end{array}$ & $\begin{array}{l}6.00 \\
6.00 \\
6.00 \\
6.00 \\
6.25 \\
6.50 \\
6.75 \\
7.00 \\
7.00 \\
7.00 \\
7.25 \\
7.25\end{array}$ & $\begin{array}{l}7.23 \\
6.90 \\
7.16 \\
7.36 \\
7.02 \\
7.06 \\
7.11 \\
7.07 \\
6.83 \\
6.62 \\
6.82 \\
6.60\end{array}$ & $\begin{array}{l}7.53 \\
7.17 \\
7.42 \\
7.61 \\
7.13 \\
7.11 \\
7.01 \\
7.06 \\
6.78 \\
6.48 \\
6.59 \\
6.34\end{array}$ & $\begin{array}{l}7.74 \\
7.39 \\
7.62 \\
7.77 \\
7.23 \\
7.18 \\
6.97 \\
7.02 \\
6.79 \\
6.48 \\
6.54 \\
6.31\end{array}$ \\
\hline 1998 & $\begin{array}{l}\text { January } \\
\text { February } \\
\text { March } \\
\text { April } \\
\text { May } \\
\text { June } \\
\text { July } \\
\text { August } \\
\text { September } \\
\text { October } \\
\text { November } \\
\text { December }\end{array}$ & $\begin{array}{l}7.56 \\
7.54 \\
7.56 \\
7.52 \\
7.48 \\
7.71 \\
7.80 \\
7.73 \\
7.46 \\
7.22 \\
6.98 \\
6.49\end{array}$ & $\begin{array}{l}5.09 \\
5.11 \\
5.03 \\
5.00 \\
5.03 \\
4.99 \\
4.96 \\
4.94 \\
4.74 \\
4.08 \\
4.44 \\
4.42\end{array}$ & $\begin{array}{l}7.25 \\
7.25 \\
7.25 \\
7.25 \\
7.25 \\
7.50 \\
7.50 \\
7.50 \\
7.50 \\
7.25 \\
6.75 \\
6.25\end{array}$ & $\begin{array}{l}6.32 \\
6.21 \\
6.19 \\
6.01 \\
6.05 \\
6.13 \\
6.20 \\
5.95 \\
5.47 \\
5.05 \\
5.02 \\
4.61\end{array}$ & $\begin{array}{l}6.06 \\
6.02 \\
5.97 \\
5.81 \\
5.85 \\
5.77 \\
5.84 \\
5.56 \\
5.11 \\
4.94 \\
4.88 \\
4.50\end{array}$ & $\begin{array}{l}6.07 \\
5.99 \\
5.87 \\
5.70 \\
5.75 \\
5.54 \\
5.56 \\
5.46 \\
5.06 \\
4.98 \\
4.85 \\
4.54\end{array}$ \\
\hline
\end{tabular}

Sources: Office for National Statistics, Financial Statistics; and IMF, Research Department.

1) The numbers are period averages, except for the clearing banks' base rate, for which monthly numbers are rates on the last Friday of the month and quarterly and annual numbers reflect the last month of the period. 
Table A20. United Kingdom: Growth Rates of Selected Monetary Aggregates 1/

(Seasonally adjusted, 12-month percent change)

\begin{tabular}{|c|c|c|c|}
\hline & MO & M4 & $\begin{array}{c}\text { M4 Sterling } \\
\text { Lending Counterpart }\end{array}$ \\
\hline Stock, end 1997 ( $\mathrm{f}$ billions) & 25.6 & 719.9 & 838.9 \\
\hline \multicolumn{4}{|l|}{ Changes to end of: } \\
\hline 1993 & 5.0 & 4.9 & 3.6 \\
\hline 1994 & 6.5 & 4.2 & 3.7 \\
\hline 1995 & 6.0 & 9.9 & 7.7 \\
\hline 1996 & 6.7 & 9.7 & 9.1 \\
\hline 1997 & 6.1 & 5.6 & 8.8 \\
\hline \multicolumn{4}{|l|}{ 1997: } \\
\hline January & 5.9 & 9.9 & 9.1 \\
\hline February & 6.3 & 11.0 & 9.1 \\
\hline March & 7.1 & 11.2 & 9.0 \\
\hline April & 5.1 & 10.3 & 8.9 \\
\hline May & 6.1 & 11.2 & 9.4 \\
\hline June & 6.3 & 11.4 & 9.5 \\
\hline July & 5.8 & 11.7 & 9.0 \\
\hline August & 5.1 & 11.6 & 8.6 \\
\hline September & 6.0 & 5.8 & 8.6 \\
\hline October & 6.5 & 5.3 & 7.8 \\
\hline November & 6.8 & 4.9 & 8.0 \\
\hline December & 6.3 & 5.6 & 9.0 \\
\hline \multicolumn{4}{|l|}{ 1998: } \\
\hline January & 7.1 & 4.8 & 8.2 \\
\hline February & 7.2 & 4.5 & 8.9 \\
\hline March & 5.6 & 4.1 & 8.4 \\
\hline April & 7.1 & 4.8 & 8.9 \\
\hline May & 6.0 & 3.7 & 8.3 \\
\hline June & 5.2 & 3.6 & 7.7 \\
\hline July & 5.4 & 4.1 & 8.4 \\
\hline August & 5.4 & 3.0 & 8.7 \\
\hline September & 6.1 & 8.7 & 8.7 \\
\hline October & 5.2 & 8.6 & 9.1 \\
\hline
\end{tabular}

Sources: Office for National Statistics, Financial Statistics; and Bank of England, Monetary and Financial Statistics.

1/MO and M4 are part of the Monetary Policy Framework. The target range for MO is 0 to 4 percent. The monitoring range for $M 4$ is 4 to 9 percent. 
Tabbe 21. United Kingdom: Contribution of Asset Counterparts to Growth in Broad Money Stock M4 I/

(In percent of stock of M4 outstanding four quarters)

\begin{tabular}{|c|c|c|c|c|c|c|c|c|c|c|}
\hline & \multirow{2}{*}{$\begin{array}{c}1994 \\
\text { QI }\end{array}$} & \multirow{2}{*}{$\begin{array}{c}1995 \\
\text { Q1 }\end{array}$} & \multirow{2}{*}{$\begin{array}{c}1996 \\
01\end{array}$} & \multicolumn{4}{|c|}{1997} & \multicolumn{3}{|c|}{1998} \\
\hline & & & & Q1 & $Q 2$ & 03 & Q4 & Q1 & $Q 2$ & $Q 3$ \\
\hline M4 & $\underline{5.8}$ & $\underline{5.1}$ & 9.7 & $\underline{11.2}$ & $\underline{11.4}$ & $\underline{5.8}$ & $\underline{56}$ & 4.1 & $\underline{3.6}$ & 8.7 \\
\hline PSBR & 87 & 6.5 & 5.5 & 3.6 & 3.2 & 23 & 1.8 & 0.1 & .0 .3 & -0.9 \\
\hline \multicolumn{11}{|l|}{ Purchases of public sector debt by } \\
\hline U.K. private sector & -5.1 & -5.2 & -2.9 & -3.5 & -3.1 & -20 & -1.9 & .1 .3 & -0.0 & 0.5 \\
\hline Sterling lending to UK private sector & 4.1 & 7.9 & 10.4 & 10.4 & 11.0 & 9.8 & 10.0 & 9.5 & 8.6 & 10.2 \\
\hline Personal sector & $(4.1)$ & (4.4) & (3.9) & (4.6) & $(4.7)$ & $(4.8)$ & $(4.7)$ & $(4.4)$ & $(4.4)$ & (4.8) \\
\hline For house purchase & 40 & 3.5 & 29 & 3,3 & 3.4 & 3.5 & 33 & 3.1 & 3.0 & $3.3^{\prime}$ \\
\hline Other & 0.2 & 0.8 & 1.0 & 1.3 & 1.4 & 1.3 & 1.3 & 14 & 1.4 & 1.6 \\
\hline Industrial and commercial companies & $(1.7)$ & $(0.7)$ & (0.9) & $(1.2)$ & (1.1) & (1.1) & $(0.9)$ & $(0.9)$ & $(0.8)$ & $(1.0)$ \\
\hline Other financial institutions & $(-18)$ & (2.8) & $(5.5)$ & $(4.7)$ & (5.1) & $(4.0)$ & $(4.4)$ & $(42)$ & (3.4) & $(4.4)$ \\
\hline Extental and foreigz currency counterpart & 1.3 & $\cdot 1.5$ & .15 & 2.4 & 27 & 3.3 & 2.7 & 2.6 & 1.6 & 0.2 \\
\hline Net non-deposit liabilities & -3.3 & -2.2 & .1 .8 & .1 .7 & -20 & -1.8 & .1 .0 & -1.4 & $\cdot 1.1$ & $\cdot 1.1$ \\
\hline
\end{tabular}

Sources: CSOBank of Englanc, and staff calcuiations.

$1 /$ Components may not add to totals due to rounding. 